Article

\title{
Efficient Oxidative Resolution of 1-Phenylphosphol-2-Ene and Diels-Alder Synthesis of Enantiopure Bicyclic and Tricyclic P-Stereogenic C-P Heterocycles
}

\author{
K. Michał Pietrusiewicz ${ }^{1, *(D)}$, Marek Koprowski ${ }^{2}$ D, Zbigniew Drzazga $^{1}$, Renata Parcheta ${ }^{1}$, \\ Elżbieta Łastawiecka ${ }^{1}$, Oleg M. Demchuk ${ }^{3}(\mathbb{D})$ and Iwona Justyniak ${ }^{4}$ \\ 1 Department of Organic Chemistry, Institute of Chemical Sciences, Faculty of Chemistry, \\ Maria Curie-Sklodowska University, Gliniana 33, 20-614 Lublin, Poland; \\ zbigniew.drzazga@poczta.umcs.lublin.pl (Z.D.); renata.parcheta@up.lublin.pl (R.P.); \\ lastawiecka@poczta.umcs.lublin.pl (E.Ł.) \\ 2 Centre of Molecular and Macromolecular Studies, Polish Academy of Sciences, Sienkiewicza 112, \\ 90-363 Lodz, Poland; mkopr@cbmm.lodz.pl \\ 3 Pharmaceutical Research Institute, Rydygiera 8, 01-793 Warsaw, Poland; O.Demchuk@IFarm.eu \\ 4 Institute of Physical Chemistry, Polish Academy of Sciences, Kasprzaka 44/52, 01-224 Warsaw, Poland; \\ iwonaj@ichf.edu.pl \\ * Correspondence: kazimierz.pietrusiewicz@poczta.umcs.lublin.pl
}

Received: 4 February 2020; Accepted: 24 February 2020; Published: 1 March 2020

\begin{abstract}
Phenylphosphol-2-ene 1-oxide is effectively resolved by L-menthyl bromoacetate to afford both $S_{\mathrm{P}}$ and $R_{\mathrm{P}}$ enantiomers of 1-phenylphosphol-2-ene 1-oxide on a multigram scale. The resolved 1-phenylphosphol-2-ene oxide has been found to undergo face-selective and endo-selective cycloadditions with a series of acyclic and cyclic dienes to produce enantiopure P-stereogenic C-P heterocycles of hexahydrophosphindole and hexahydrobenzophosphindole as well as phospha[5.2.1.0 $\left.0^{2,6}\right]$ decene and phospha[5.2.2.0 2,6 undecene structures. Conversions of these cycloadducts to the fully saturated heterocyclic systems as well as to their P (III), P = S, P = Se and $\mathrm{P}-\mathrm{BH}_{3}$ derivatives have been demonstrated to occur with retention of configuration and preservation of configurational homogeneity at $\mathrm{P}$. A perplexing case of stereomutation at $\mathrm{P}$ during reduction of a tricyclic $\beta$-hydroxy phosphine oxide by $\mathrm{PhSiH}_{3}$ at $80^{\circ} \mathrm{C}$ has been recorded.
\end{abstract}

Keywords: P-stereogenicity; 1-phenylphosphol-2-ene 1-oxide; resolution; [4+2] cycloaddition; polycyclic phosphorus heterocycles; $\mathrm{P}=\mathrm{O}$ reduction; optically active phosphines

\section{Introduction}

Optically active P-stereogenic organophosphorus compounds are of great importance in organic synthesis [1-4]. The most spectacular example of their utility has been the use of $\left(S_{P}\right)$-PAMP \{o-anisylmethylphenylphosphine $\}$ and $\left(R_{\mathrm{P}}, R_{\mathrm{P}}\right)$-DIPAMP $\{1,2$-bis(o-anisylmethylphenylphosphine)ethane $\}$ di as chiral ligands in rhodium-catalyzed asymmetric hydrogenation of enamides [5] which led to the first application of such a process in the industrial production, i.e., the Monsanto L-DOPA process [6] However, P-stereogenicity is not a natural phenomenon, and, from the very beginning [7], it had to be generated in the lab. Despite many developed asymmetric syntheses [1,7-18], desymmetrizations [14,19-27] and kinetic resolutions [28-34], practical preparations of optically active P-stereogenic compounds are still relying in great part on classical resolution of racemates $[7,8,35-40]$. The latter has the advantage to rely on cheap and often recoverable chiral auxiliaries, uses crystallization for separation of the P-epimers and, 
by avoiding chromatography, usually secures convenient access to resolved P-stereogenic compounds in multigram quantities [41]. In our studies, we have found that several synthetically useful P-stereogenic compounds could be readily resolved into enantiomers by the use of L-menthyl bromoacetate as the chiral auxiliary $[38,39,42,43]$. Due to versatility of its acetate function, it could serve either as the latent methyl group mounted on P during the resolution process [43,44], or it could be used as the classical chiral auxiliary that is removed in the last step as the whole $[38,39]$.

In this paper, we wish to present the use of L-menthyl acetate auxilliary for efficient resolution of racemic 1-phenyl-phosphol-2-ene 1-oxide (1), one of the parent five-members of P-C-heterocycles readily available on the multigram scale by the McCormack process [45]. The chemistry of $\mathbf{1}$ is very rich and offers the possibility of transforming it into many other organophosphorus compounds through the use of its double bond functionality in Michael-type additions [45], Diels-Alder cycloadditions [46,47], 1,3-dipolar cycloadditions $[28,30,48,49]$, and Heck reactions $[24,33,50,51]$. The utility of the resolved $\mathbf{1}$ as a dienophile in stereoselective Diels-Alder synthesis of a series of optically active bicyclic and tricyclic C-P-heterocyclic systems will be demonstrated.

\section{Results and Discussions}

\subsection{Synthesis and Resolution of 1-Phenylphosphol-2-Ene 1-Oxide}

Racemic $\mathbf{1}$ was synthesized from butadiene and $P, P$-dichlorophenylphosphine via intermediate cyclic chlorophosphonium chloride (a 1,4-cycloadduct) which after a hydrolytic work-up afforded rac-1 in good yield (Scheme 1).

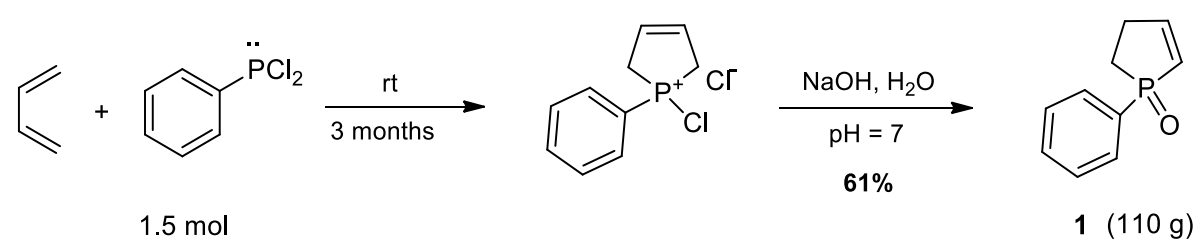

Scheme 1. Synthesis of racemic 1-phenylphosphol-2-ene 1-oxide (1) by the McCormack route.

The subsequent resolution of $r a c-\mathbf{1}$ started with its reduction to the corresponding phosphine 2 by treatment with $\mathrm{PhSiH}_{3}$ at the temperature not exceeding $60{ }^{\circ} \mathrm{C}$ in order to avoid concomitant reduction of the double bond (Scheme 2). Then, the resulting phosphine 2 was quaternized by L-menthyl bromoacetate at room temperature to afford a ca. 1:1 mixture of the two P-epimeric quaternary phosphonium salts 3 . One of them, the $\left(S_{\mathrm{P}}\right)-3$, crystallized out from the reaction mixture in great predominance over the more soluble $\left(R_{\mathrm{P}}\right)-3(>9: 1)$. Recrystallization of the filtered crystals from AcOEt-EtOH (10:1) yielded pure $S_{\mathrm{P}}-3$ epimer in 37\% yield. Evaporation of the filtrate and recrystallization of the residue from benzene-hexane (10:1), or from toluene, yielded in turn pure $R_{\mathrm{P}}-3$ epimer in $32 \%$ yield. Conversion of the P-epimeric phosphonium salts to the corresponding enantiopure phospholene oxides was conveniently achieved by removal of the auxilliary L-menthyl acetate group either by the Wittig reaction with benzaldehyde as originally applied $[7,10]$ or, as found later [38], by simple alkaline hydrolysis. According to the literature, clean retention of configuration at $P$ could have been expected in both cases [7,52-54]. In this way, over $20 \mathrm{~g}$ amounts of each enantiomer of $\mathbf{1}$ can be obtained in a single bench-top batch.

The assignment of the $\mathrm{S}$ configuration to the dextrorotatory $\mathbf{1}$ and the $\mathrm{R}$ configuration to the levorotatory $\mathbf{1}$ follows from the previous unequivocal X-ray based assignment of $\left(S_{P}\right)-(+)-\mathbf{1}[29]$. The enantiomeric purity of the synthesized enantiomers of 1 was determined by running their ${ }^{1} \mathrm{H}$ and ${ }^{31} \mathrm{P}$ NMR spectra in the presence of equimolar amounts of (S)-3,5-dinitro- $N$ - $\alpha$-phenylethyl-benzamide as a chiral solvating agent (Kagan's reagent) according to the described procedure [55]. Because the presence of any signals of the opposite enantiomer could not be detected in either of the spectrums, the enantiomeric purity of both $\left(S_{P}\right)-\mathbf{1}$ and $\left(R_{\mathrm{P}}\right)-\mathbf{1}$ was assigned to be more than $98 \%$ ee. 


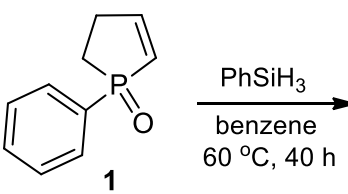<smiles>C1=CP(c2ccccc2)CC1</smiles><smiles>COC(=O)CBr</smiles><smiles>COC(=O)C[P+]1(c2ccccc2)C=CCC1</smiles>

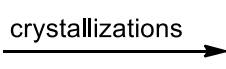<smiles>COC(=O)C[P+]1(c2ccccc2)C=CCC1</smiles><smiles>O=C(C[P+]1(c2ccccc2)C=CCC1)O[Na]</smiles>

hydrolysis retention<smiles>O=P1(c2ccccc2)C=CCC1</smiles>

$S_{P^{-1}}$

$33,3 \%$ (overall)

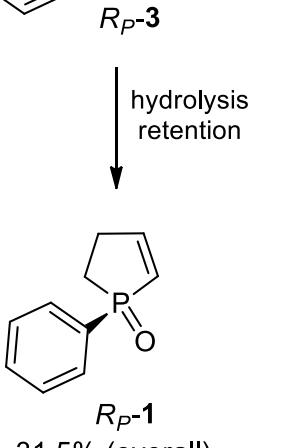

$31.5 \%$ (overall)

Scheme 2. Resolution protocol for 1-phenylphosphol-2-ene 1-oxide (1).

\subsection{Synthesis of Optically Active Bicyclic and Tricyclic P-Sterogenic Phospholene Derivatives}

Ready synthesis of enantiomers of $\mathbf{1}$ opens up the possibility of synthesizing also other optically active P-stereogenic heterocyclic compounds by employment of the conjugated double bond functionality present in its structure $[24,28,30,33,45-50]$. To illustrate this potential, we decided to use $\left(S_{\mathrm{P}}\right)-\mathbf{1}$ as a dienophile in the Diels-Alder reactions with acyclic and cyclic dienes to synthesize optically active bicyclic and tricyclic C,P-heterocycles [56-60]. The additions of rac-1 to acyclic dienes have been already described to occur at $260^{\circ} \mathrm{C}$ and to afford the endo cycloadduct [46]. The required elevated temperature clearly indicated that phosphol-2-ene oxide is a rather poor dienophile. Our efforts to optimize the conditions of this reaction using rac-1 and butadiene led us eventually to conclude that the best way to conduct the cycloaddition is to use a glass reactor (to avoid possible metal catalysis in equilibration of $\left(S_{\mathrm{P}}\right)-\mathbf{1}$ with its symmetrical phosphol-3-ene counterpart), use toluene as solvent, carry out the reaction at $190-200{ }^{\circ} \mathrm{C}$, and use 6-9 equiv. of the diene added in two or three portions over a period of 2-6 days. Interestingly, attempted Lewis acid catalysis by $\mathrm{FeCl}_{3}, \mathrm{SnCl}_{4}$, or $\mathrm{AlCl}_{3}$ proved inefficient. Even with $\mathrm{AlCl}_{3}$, which appeared to be the best of the three, the reaction temperature could be in some cases lowered to $100^{\circ} \mathrm{C}$, but the achieved overall yields were still inferior to those observed under the optimized thermal conditions.

When $\left(S_{\mathrm{P}}\right)-1$ was reacted with butadiene under the optimized conditions, the $\left(S_{\mathrm{P}}\right)$-cis-hexahydro-1-phenylphosphindole 1-oxide (4) was obtained in 50\% isolated yield (Scheme 3).
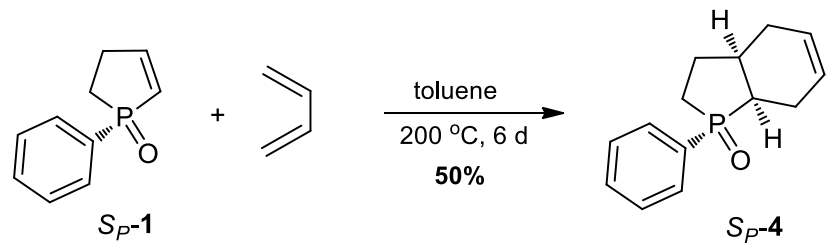

Scheme 3. Cycloaddition of $\left(S_{\mathrm{P}}\right)-\mathbf{1}$ to butadiene. 
Enantiomeric purity of $\left(S_{\mathrm{P}}\right)-\mathbf{4}$ was determined by ${ }^{1} \mathrm{H}$ NMR using Kagan's solvating agent [55] to be $>98 \%$ ee. The confirmation of the very high enantiomeric purity of the synthesized $\left(S_{\mathrm{P}}\right)-4$ has also attested to the fact that racemizing of the starting $\left(S_{P}\right)-\mathbf{1}$ through its possible reversible equilibration with symmetrical 1-phenylphosphol-3-ene 1-oxide under such demanding thermal conditions has been negligible, if any.

Next, to check the possibility of steroselective conversion of $\left(S_{\mathrm{P}}\right)-4$ to the corresponding $\mathrm{P}, \mathrm{C}$-stereogenic enantiopure phosphine $\left(R_{\mathrm{P}}\right)-5,\left(S_{\mathrm{P}}\right)-4$ was treated with $\mathrm{PhSiH}_{3}$ at $80{ }^{\circ} \mathrm{C}$ to yield the desired phosphine in $92 \%$ isolated yield (Scheme 4). To confirm the expected retention of configuration at $\mathrm{P}$ in the reduction step [61,62], the resulting phosphine was reoxidized by $30 \% \mathrm{H}_{2} \mathrm{O}_{2}$, known as a stereoretentive oxidant in phosphorus chemistry $[7,63]$. The oxidation gave back $\left(S_{\mathrm{P}}\right)-4$ of practically the same specific rotation sign and value as the starting one, attesting thus to the clean retention of configuration at $\mathrm{P}$ in the reduction step. Protection of $\left(R_{\mathrm{P}}\right)-5$ by $\mathrm{BH}_{3}$ was best achieved by using $\mathrm{NaBH}_{4} / \mathrm{AcOH}\left[64\right.$ ] yielding phosphine-borane $\left(R_{\mathrm{P}}\right)-6$ in $76 \%$ yield, while, with $\mathrm{BH}_{3} \times \mathrm{THF}$ (or $\mathrm{BH}_{3} \times \mathrm{SMe}_{2}$ ), it was much less efficient (ca. $36 \%$ or less) probably due to interfering reactivity of the double bond present in its structure. In turn, oxidation of $\left(R_{\mathrm{P}}\right)-5$ by elemental sulfur and selenium gave the corresponding phosphine sulfide $\left(R_{\mathrm{P}}\right)-7$ and phosphine selenide $\left(R_{\mathrm{P}}\right)-8$, respectively, in practically quantitative yield (Scheme 4). In addition, these conversions have been known to occur with clean retention of configuration at $\mathrm{P}[7]$, and the synthesized sulfide and selenide derivatives of $\left(R_{\mathrm{P}}\right)-5$ should be considered as virtually enantiopure as well.
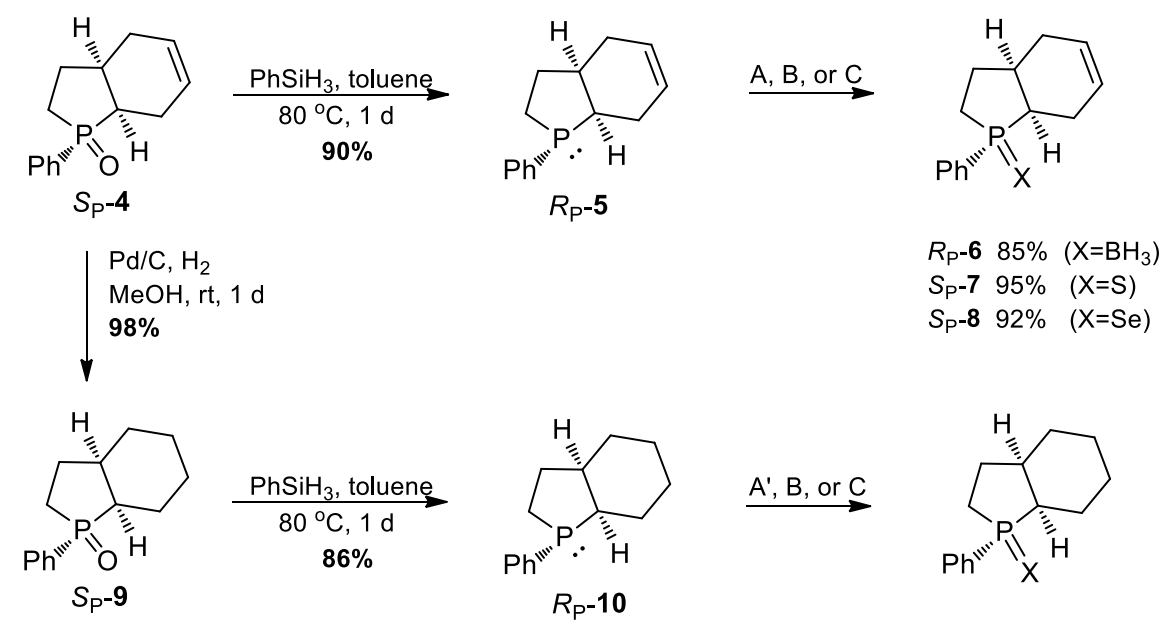

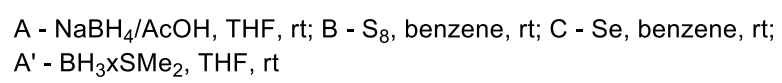

$R_{\mathrm{P}}-1195 \%\left(\mathrm{X}=\mathrm{BH}_{3}\right)$

$S_{\mathrm{P}}-1294 \% \quad(\mathrm{X}=\mathrm{S})$

$S_{\mathrm{P}}-13 \quad 89 \% \quad(\mathrm{X}=\mathrm{Se})$

Scheme 4. Conversion of $\left(S_{\mathrm{P}}\right)-4$ to other unsaturated P-derivatives and their saturated counterparts.

Hydrogenation of the double bond in $\left(S_{\mathrm{P}}\right)$-4 gave in turn fully saturated cis-octahydrophosphindole oxide $\left(S_{\mathrm{P}}\right)-9$. As before, reduction of $\left(S_{\mathrm{P}}\right)^{-9}$ by $\mathrm{PhSiH}_{3}$ gave the corresponding saturated phosphine $\left(R_{\mathrm{P}}\right)-\mathbf{1 0}$, which could be further transformed to phosphine-borane $\left(R_{\mathrm{P}}\right)-\mathbf{1 1}$ as well as to the phosphine sulfide $\left(S_{\mathrm{P}}\right)-\mathbf{1 2}$ and phosphine selenide $\left(S_{\mathrm{P}}\right)-\mathbf{1 3}$ by boranation, and oxidation by sulfur and selenium, respectively. This time, however, boranation of $\left(R_{\mathrm{P}}\right)-\mathbf{1 0}$ by $\mathrm{BH}_{3} \times \mathrm{SMe}_{2}$ gave the best results and proved more efficient than $\mathrm{NaBH}_{4} / \mathrm{AcOH}$ ( $95 \%$ vs. $87 \%$, respectively) (Scheme 4 ).

With the protocols for the cycloaddition and for the basic transformations of the cycloaddition product established, we turned our attention towards using these protocols for synthesis of the more rigid enantiopure P-stereogenic phosphines which could have potential relevance to asymmetric catalysis [2,4]. Towards this end, we selected cyclopentadiene, cyclohexadiene, and anthracene as well as hydroxybenzocyclobutene as dienes in order to prepare polycyclic phosphines containing rigidified bridged skeleton $[65,66]$. As with butadiene, also with these dienes, all the cycloadditions as 
well as the following transformations were tested first for conditions and efficiency using $r a c-1$ as the substrate. Thus, the reaction conditions and yields of the syntheses starting with $\left(S_{\mathrm{P}}\right)-\mathbf{1}$ which follow below should be considered as the optimized ones.

The cycloaddition reaction of $\left(S_{P}\right)-\mathbf{1}$ to cyclopentadiene is shown in Scheme 5. In spite of the fact that with this reactive diene the reaction could be carried out at the temperature lowered to $160{ }^{\circ} \mathrm{C}$, the best results were obtained by running it at $200^{\circ} \mathrm{C}$ for two days and by adding an extra portion of fresh cyclopentadiene after one day. In this way, $\left(S_{P}\right)-\mathbf{1 4}$ was obtained in $54 \%$ isolated yield after chromatographic separation from some minor products (one of those, not isolated, was identified by GC-MS analysis as being derived from the primary cycloadduct by sequential addition of another molecule of cyclopentadiene).<smiles>CCCP(C)c1ccccc1</smiles>
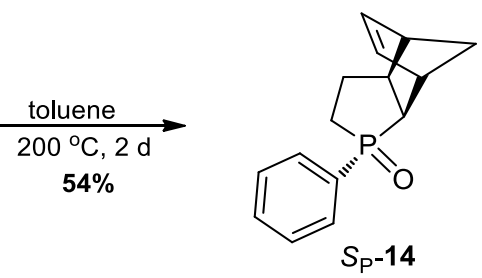

Scheme 5. Cycloaddition of $\left(S_{\mathrm{P}}\right)-1$ to cyclopentadiene.

The enantiomeric purity of $\left(S_{\mathrm{P}}\right)-\mathbf{1 4}$ was confirmed by ${ }^{1} \mathrm{H}$ NMR using Kagan's solvating agent [55] to be $>98 \%$ ee. Similar to before, reduction of $\left(S_{\mathrm{P}}\right)-\mathbf{1 4}$ by $\mathrm{PhSiH}_{3}$ at $80^{\circ} \mathrm{C}$ gave saturated phosphine $\left(S_{\mathrm{P}}\right)$-15 which after boranation with $\mathrm{NaBH}_{4} / \mathrm{AcOH}$ and oxidation by sulfur and selenium gave phosphine-borane $\left(S_{\mathrm{P}}\right) \mathbf{- 1 6}$, sulfide $\left(S_{\mathrm{P}}\right)-\mathbf{1 7}$, and selenide $\left(S_{\mathrm{P}}\right)-\mathbf{1 8}$, respectively, in very good yields (Scheme 6). Reoxidation of the phosphine by $\mathrm{H}_{2} \mathrm{O}_{2}$ gave back $\left(S_{\mathrm{P}}\right)-\mathbf{1 4}$ of practically the same specific rotation sign and value as the starting one, confirming again the clean retention of configuration at $\mathrm{P}$ in the reduction step.
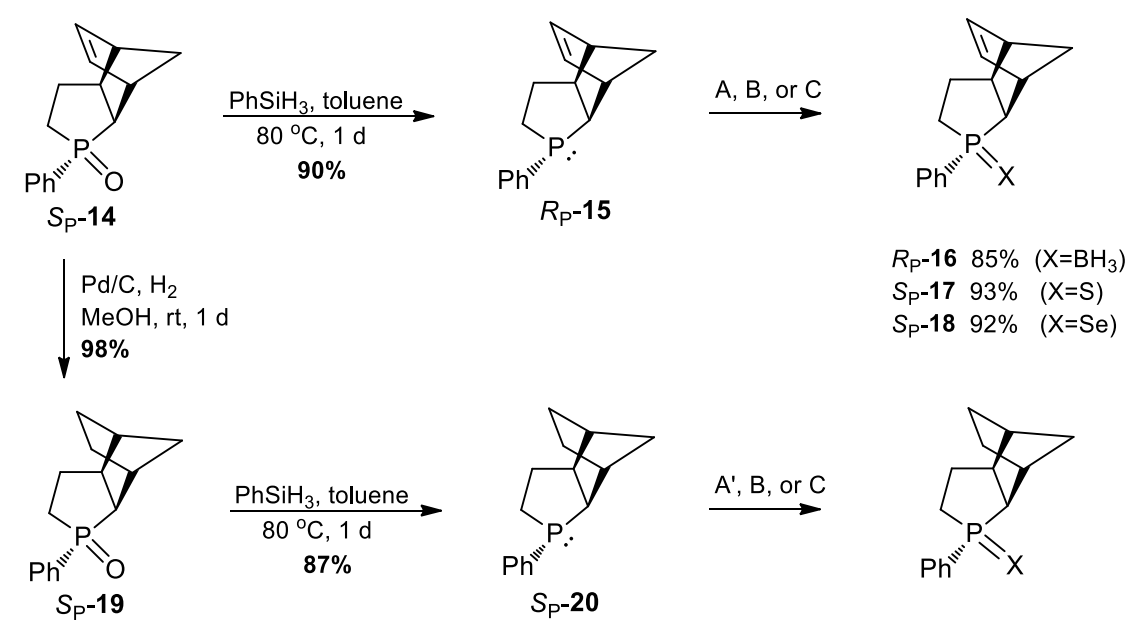

A - $\mathrm{NaBH}_{4} / \mathrm{AcOH}, \mathrm{THF}, \mathrm{rt}$; $\mathrm{B}-\mathrm{S}_{8}$, benzene, rt; C - Se, benzene, rt; $\mathrm{A}^{\prime}-\mathrm{BH}_{3} \mathrm{xSMe} 2, \mathrm{THF}, \mathrm{rt}$.

Scheme 6. Conversion of $\left(S_{\mathrm{P}}\right)-\mathbf{1 4}$ to other unsaturated P-derivatives and their saturated counterparts.

Hydrogenation of the double bond in $\left(S_{\mathrm{P}}\right)$-14 gave the fully saturated tricyclic phosphine oxide $\left(S_{\mathrm{P}}\right)-19$ in $98 \%$ yield. As before, reduction of $\left(R_{\mathrm{P}}\right)-19$ by $\mathrm{PhSiH}_{3}$ at $80^{\circ} \mathrm{C}$ gave saturated phosphine $\left(R_{\mathrm{P}}\right)-20$ which after boranation with $\mathrm{BH}_{3} \times \mathrm{SMe}_{2}$ and oxidation by sulfur and selenium gave phosphine-borane $\left(R_{\mathrm{P}}\right)$-21, sulfide $\left(S_{\mathrm{P}}\right)-\mathbf{2 2}$, and selenide $\left(S_{\mathrm{P}}\right)$-23, respectively, in very good yields (Scheme 6$)$. 
Finally, the endo stereochemistry of the cycloaddition of $\left(S_{\mathrm{P}}\right)-\mathbf{1}$ to cyclopentadiene was unequivocally confirmed by $\mathrm{X}$-ray analysis of the saturated oxide rac-19 obtained in preliminary optimizing reactions starting with rac-1 (Figure 1).

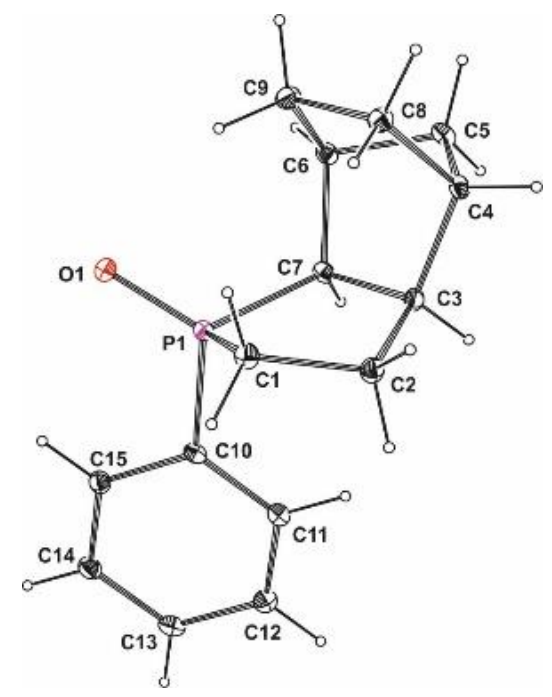

Figure 1. Molecular structure of rac-19 with thermal ellipsoids set at $40 \%$ probability.

Cycloaddition of $\left(S_{\mathrm{P}}\right)-\mathbf{1}$ to cyclohexadiene at $190{ }^{\circ} \mathrm{C}$ was studied next, which gave the tricyclic phosphaundecene oxide $\left(S_{\mathrm{P}}\right)$-24 in $80 \%$ isolated yield (Scheme 7). The enantiomeric purity of $\left(S_{\mathrm{P}}\right)-24$ of more than $98 \%$ ee was again confirmed by ${ }^{1} \mathrm{H}$ NMR using Kagan's solvating agent [55].
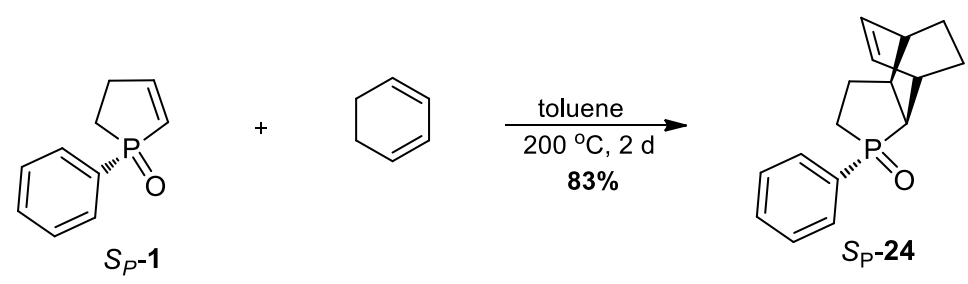

Scheme 7. Cycloaddition of $\left(S_{\mathrm{P}}\right)-1$ to cyclohexadiene.

Stereoretentive conversion of $\left(S_{\mathrm{P}}\right)-24$ to the corresponding tricyclic phosphine $\left(R_{\mathrm{P}}\right)-25$, phosphine-borane $\left(R_{\mathrm{P}}\right)$-26, sulfide $\left(S_{\mathrm{P}}\right)$-27 and selenide $\left(S_{\mathrm{P}}\right)$-28 in very good yields is shown in Scheme 8. Reoxidation of the phosphine by $\mathrm{H}_{2} \mathrm{O}_{2}$ gave back $\left(S_{\mathrm{P}}\right)-24$ of practically the same specific rotation sign and value as the starting one, confirming again the clean retention of configuration at $\mathrm{P}$ in the reduction step.

As before, to characterize also the corresponding fully saturated tricyclic phosphaundecane derivatives, $\left(S_{\mathrm{P}}\right)$-24 was hydrogenated over $\mathrm{Pd} / \mathrm{C}$ and gave saturated oxide $\left(S_{\mathrm{P}}\right)-\mathbf{2 9}$ in $98 \%$ isolated yield. Subsequent reduction of $\left(S_{\mathrm{P}}\right)-29$ by $\mathrm{PhSiH}_{3}$ gave saturated phosphine $\left(R_{\mathrm{P}}\right)-30$ from which $\left(R_{\mathrm{P}}\right)-31$, $\left(S_{\mathrm{P}}\right)$-32, and $\left(S_{\mathrm{P}}\right)-33$ were obtained by complexation with $\mathrm{BH}_{3} \times \mathrm{THF}$, and oxidation with $\mathrm{S}_{8}$ and $\mathrm{Se}$, respectively (Scheme 8 ).

The expected endo stereocourse of the cycloadditon of cyclohexadiene to 1 was confirmed by an $\mathrm{X}$-ray analysis of phosphine-borane rac-26 available from preliminary optimizing experiments starting with rac-1 (Figure 2). 


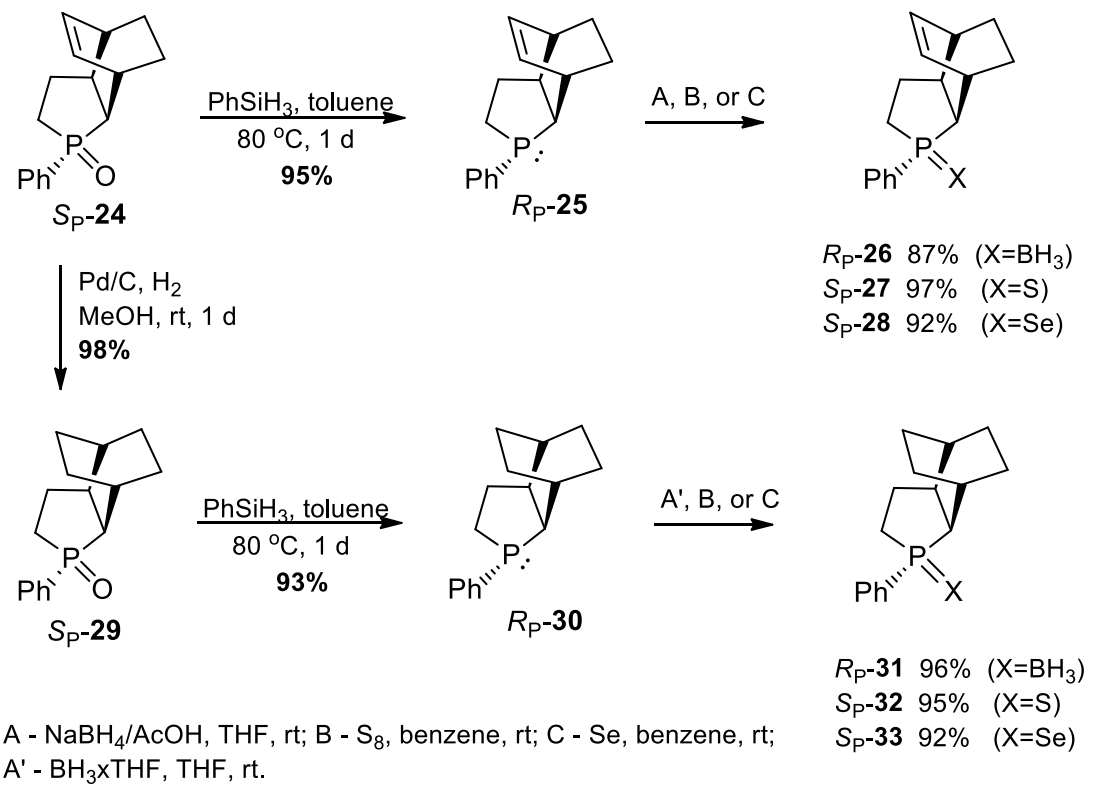

Scheme 8. Conversion of $\left(S_{\mathrm{P}}\right)$-24 to other unsaturated P-derivatives and their saturated counterparts.

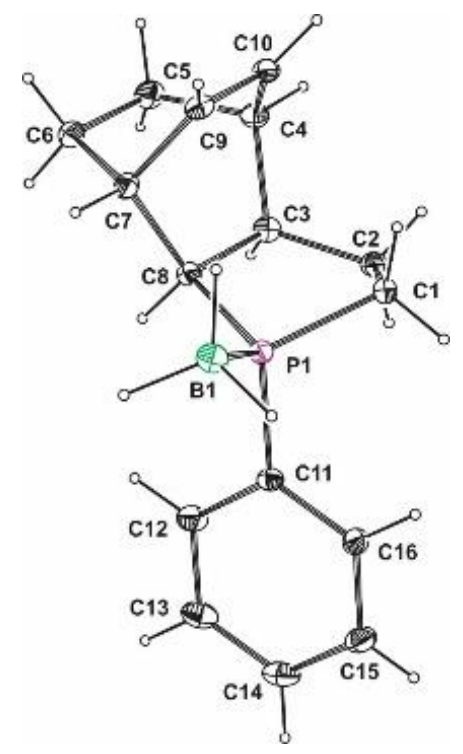

Figure 2. Molecular structure of rac-26 with thermal ellipsoids set at $40 \%$ probability.

In turn, extending the cyclohexadiene structure to anthracene enabled to produce a pentacyclic cycloadduct $\left(S_{\mathrm{P}}\right)$-34 possessing still more sterically congested phosphorus center. As shown in Scheme 9, the pentacyclic cycloadduct $\left(S_{\mathrm{P}}\right)-34$ was obtained in a good $86 \%$ yield. In addition, in this case, more than $98 \%$ ee enantiomeric purity of the cycloadduct was confirmed by its ${ }^{1} \mathrm{H}$ NMR spectra recorded in the presence of the Kagan's solvating agent. Subsequently, $\left(S_{\mathrm{P}}\right)-34$ was reduced to the corresponding phosphine $\left(R_{\mathrm{P}}\right)-35$ from which the other virtually enantiopure P-derivatives $\left(R_{\mathrm{P}}\right)-36,\left(S_{\mathrm{P}}\right)-37$, and $\left(S_{\mathrm{P}}\right)-\mathbf{3 8}$ were obtained with retention of configuration at $\mathrm{P}$. In this case, however, reduction of $\left(S_{\mathrm{P}}\right)-\mathbf{3 4}$ by $\mathrm{Cl}_{3} \mathrm{SiH} /$ pyridine and boranation of $\left(R_{\mathrm{P}}\right)-35$ by $\mathrm{BH}_{3} \times \mathrm{SMe}_{2}$ gave somewhat better results than use of $\mathrm{PhSiH}_{3}$ and $\mathrm{BH}_{3} \times \mathrm{THF}$ (or $\mathrm{NaBH}_{4} / \mathrm{AcOH}$ ), respectively. As before, reoxidation of $\left(R_{\mathrm{P}}\right)-35$ by $\mathrm{H}_{2} \mathrm{O}_{2}$ gave back $\left(S_{\mathrm{P}}\right)-34$ of practically the same specific rotation sign and value as the starting one, confirming again the clean retention of configuration at $\mathrm{P}$ in the reduction step. 
<smiles>O=P1(c2ccccc2)C=CCC1</smiles>

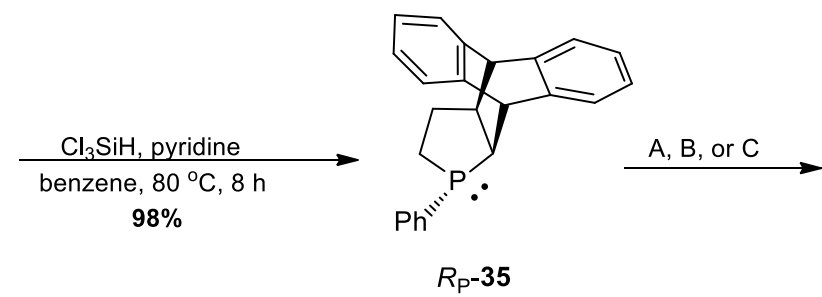

A - $\mathrm{BH}_{3} \mathrm{xSMe}$, THF, rt; B - S 8 , benzene, rt; C - Se, benzene, rt
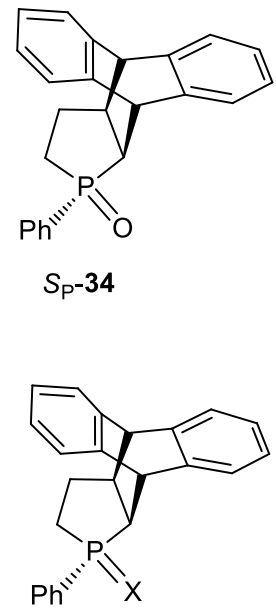

$\begin{array}{lll}R_{\mathrm{P}-36} & 96 \% & \left(\mathrm{X}=\mathrm{BH}_{3}\right) \\ S_{\mathrm{P}}-37 & 92 \% & (\mathrm{X}=\mathrm{S}) \\ S_{\mathrm{P}}-38 & 90 \% & (\mathrm{X}=\mathrm{Se})\end{array}$

Scheme 9. Cycloaddition of $\left(S_{\mathrm{P}}\right)-\mathbf{1}$ to anthracene and synthesis of other cycloadduct P-derivatives.

Next, $\left(S_{\mathrm{P}}\right)-\mathbf{1}$ was subjected to a reaction with highly reactive lithiated $\alpha$-oxy-o-xylilene generated in situ from benzocyclobutenol and $n$-BuLi $[67,68]$. The reaction was effectively carried out at $-78{ }^{\circ} \mathrm{C}$ and provided hexahydrobezophosphindole $\left(S_{\mathrm{P}}\right)-39$ in $90 \%$ isolated yield and of very high $(>98 \%$ ee) enantiomeric purity, as confirmed by its ${ }^{1} \mathrm{H}$ NMR spectra recorded in the presence of the Kagan's solvating agent [55] (Scheme 10).
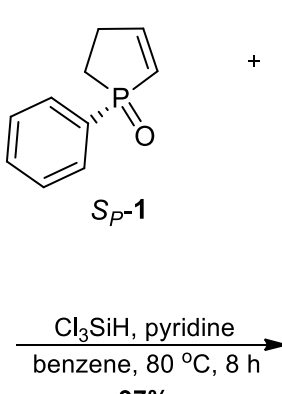

$97 \%$<smiles>OC1Cc2ccccc21</smiles>

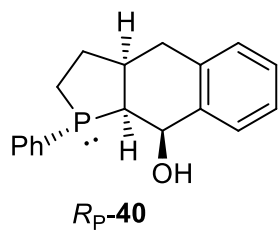

A - $\mathrm{BH}_{3} \times \mathrm{SMe}_{2}$, THF, rt; B - $\mathrm{S}_{8}$, benzene, rt; C - Se, benzene, rt

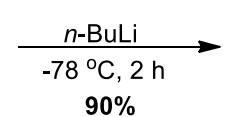

A, B, or C<smiles>c1ccccc1</smiles><smiles>[X][P@]1(c2ccccc2)CC[C@H]2Cc3ccccc3[C@@H](O)[C@@H]21</smiles>

$R_{\mathrm{P}}-\mathbf{4 1} 95 \%\left(\mathrm{X}=\mathrm{BH}_{3}\right)$

$S_{\mathrm{P}}-42 \quad 92 \% \quad(\mathrm{X}=\mathrm{S})$

$S_{\mathrm{P}}-43 \quad 94 \% \quad(\mathrm{X}=\mathrm{Se})$

Scheme 10. Synthesis of cycloadduct $\left(S_{\mathrm{P}}\right)-\mathbf{3 9}$ and its other P-derivatives 41-43.

Attempted confirmation of the expected regio and endo selectivity of the cycloaddition by X-ray structural determination of $\mathrm{rac}-\mathbf{3 9}$ was only partially successful. The collected data could not be fully refined because of poor quality of the monocrystals obtained. However, the data were sufficiently accurate to provide confirmation of the expected stereochemistry of the process as judged from the obtained unoptimized molecular structures which are displayed in Figure 3.

To enable characterization of other hexahydrobenzophosphindole P-derivatives, oxide $\left(S_{\mathrm{P}}\right)$-39 was subjected to reduction by $\mathrm{Cl}_{3} \mathrm{SiH} /$ pyridine to yield the corresponding phosphine $\left(R_{\mathrm{P}}\right)-\mathbf{4 0}$ from which the phosphine-borane $\left(R_{\mathrm{P}}\right)-\mathbf{4 1}$, phosphine sulfide $\left(S_{\mathrm{P}}\right) \mathbf{- 4 2}$, and phosphine selenide $\left(S_{\mathrm{P}}\right)-\mathbf{4 3}$ were obtained (Scheme 10). The phosphine $\left(R_{\mathrm{P}}\right)-\mathbf{4 0}$ was also reoxidized by $\mathrm{H}_{2} \mathrm{O}_{2}$ and provided $\left(S_{\mathrm{P}}\right)-39$ of practically the same specific rotation sign and value as the starting oxide. 

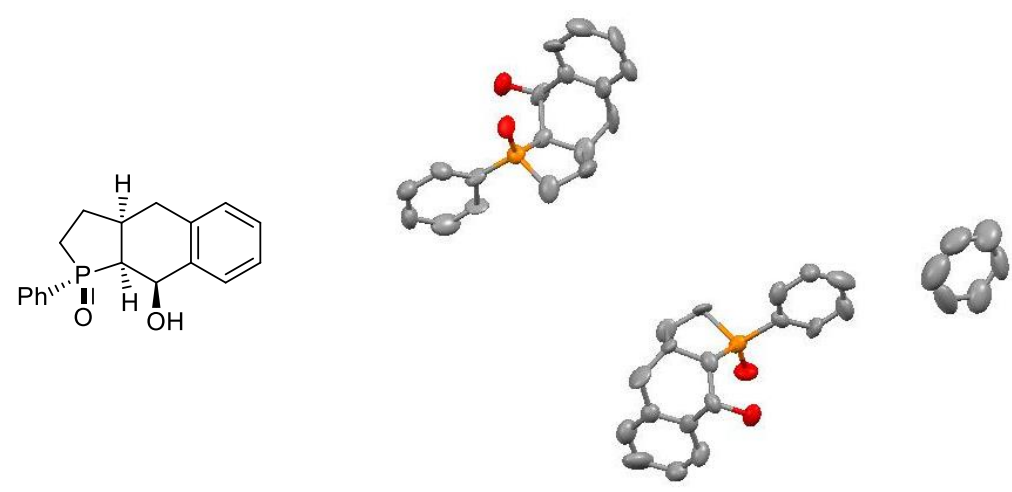

Figure 3. Molecular structure of rac-39: an overview picture.

It is important to note, however, that attempted reduction of $\left(S_{\mathrm{P}}\right)-39$ by $\mathrm{PhSiH}_{3}$ at $80{ }^{\circ} \mathrm{C}$ for two days led unexpectedly to the formation of two reduction products as revealed by the ${ }^{31} \mathrm{P} N \mathrm{NM}$ spectrum showing two phosphine signals at $\delta_{\mathrm{P}}-8.35$ and $-3.67 \mathrm{ppm}$ in a 7:3 ratio, respectively. Most probably, the observed loss of configurational integrity at $\mathrm{P}$ can be ascribed to an apparently lowered inversion barrier of the produced phosphine causing its substantial epimerization at $\mathrm{P}$ even at $80^{\circ} \mathrm{C}$. As shown in Scheme 10, using a stronger stereoretentive reductant, e.g., $\mathrm{Cl}_{3} \mathrm{SiH}$, instead of $\mathrm{PhSiH}_{3}$, allowed to completely avoid the P-epimerization by carrying out the reduction at lower temperature and in shorter time $\left(60^{\circ} \mathrm{C}, 9 \mathrm{~h}\right)$.

Finally, in the course of efforts to obtain a better crystallizing derivative, rac-39 was reacted with triflic acid and DCC in dry pyridine/DMSO mixture. A few crystals, which were fished out from the post-reaction mixture, were found suitable for an X-ray analysis. The solved molecular structure of this product is shown in Figure 4.<smiles>O=P(O)(c1ccccc1)[n+]1ccccc1C1c2ccccc2CC2CCCCC21</smiles>

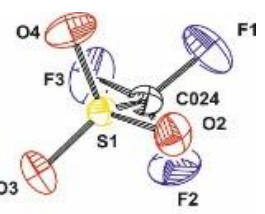

$$
\text { rac-44 }
$$

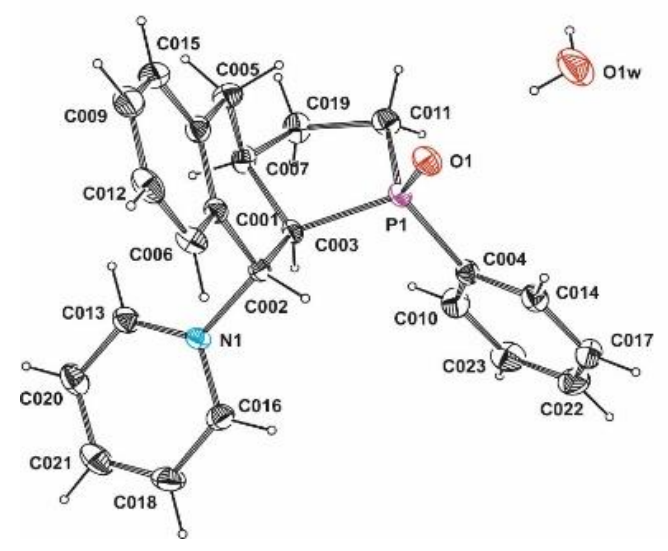

Figure 4. Molecular structure of $r a c-44$ with thermal ellipsoids set at $40 \%$ probability.

As can be seen, it turned out to be a (hexahydrobenzophosphindole-9-yl)pyridinium triflate 44, which was formed from 39 and pyridine, most probably, via a modified Steglich esterification process [69] as visualized in Scheme 11. 


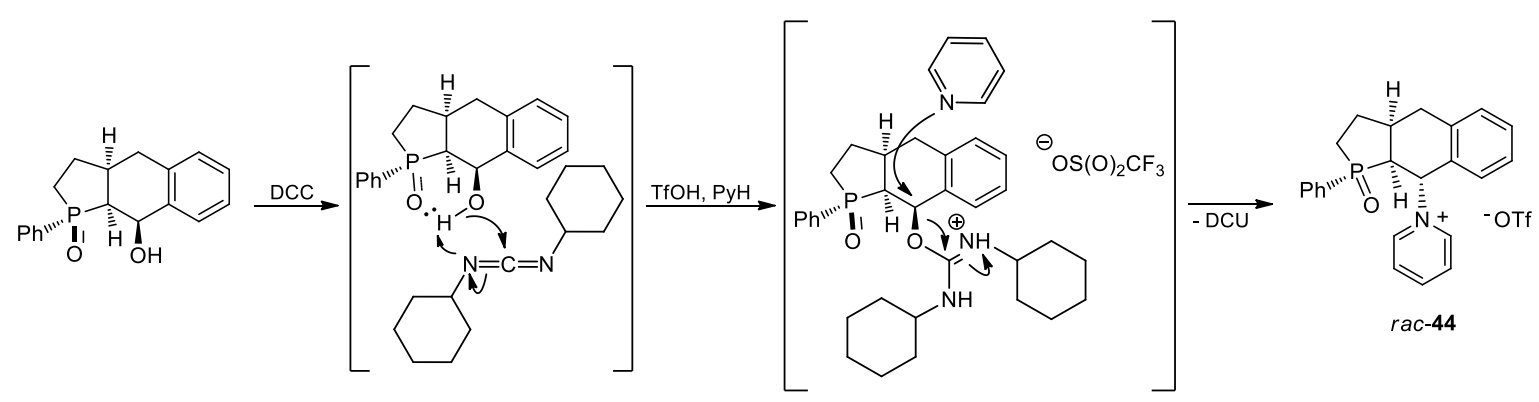

Scheme 11. A plausible synthetic path for 44 .

The revealed structure of $\mathbf{4 4}$ eventually provided the sought unequivocal confirmation of the endo stereocourse of the cycloaddition step. Thus, it has been proven that, also with $\alpha$-oxy-o-xylilene, $\left(S_{\mathrm{P}}\right)-\mathbf{1}$ undergoes the face- and regioselective cycloaddition in the endo mode.

\section{Materials and Methods}

\subsection{General Information}

The reagents were purchased from commercial suppliers and used without further purification. Solvents were dried and distilled under argon before use. All of the reactions involving formation and further conversions of phosphines were carried out under argon atmosphere with attempted complete exclusion of air from the reaction vessels and solvents, including those used in the work-up. Nuclear magnetic resonance (NMR) spectra were recorded on a Bruker AV300 $\left({ }^{1} \mathrm{H} 300 \mathrm{MHz},{ }^{31} \mathrm{P}\right.$ 121.5 MHz, ${ }^{13} \mathrm{C}$ NMR $\left.75 \mathrm{MHz}\right)$ and Bruker AV500 $\left({ }^{1} \mathrm{H} 500 \mathrm{MHz},{ }^{31} \mathrm{P} 202 \mathrm{MHz},{ }^{13} \mathrm{C} \mathrm{NMR} 126 \mathrm{MHz}\right)$ spectrometers (Bruker; Billerica, Ma., USA). All spectra were obtained in $\mathrm{CDCl}_{3}$ solutions, unless mentioned otherwise, and the chemical shifts $(\delta)$ are expressed in ppm using internal reference to TMS and external reference to $85 \% \mathrm{H}_{3} \mathrm{PO}_{4}$ in $\mathrm{D}_{2} \mathrm{O}$ for ${ }^{31} \mathrm{P}$. Coupling constants $(J)$ are given in $\mathrm{Hz}$. The abbreviations of signal patterns are as follows: s-singlet, d-doublet, t-triplet, q-quartet, m-multiplet, b-broad, and i-intensive. NMR determinations of enantiomeric purity of phosphine oxides were performed in $\mathrm{CDCl}_{3}$ in the presence of 1.1 equivalents of (S)-3,5-dinitro- $N$ - $\alpha$-phenylethyl-benzamide as described before. [55]. Elemental analyses were measured on the PerkinElmer CHN 2400. Optical rotations were measured in a $1 \mathrm{dm}$ cell on a PerkinElmer 341LC digital polarimeter at ambient temperature. Thin-layer chromatography (TLC) was carried out on silica gel (Kieselgel 60, F254 on aluminum sheet, Merck). All separations and purifications by column chromatography were conducted by using Merck Silica gel 60 (230-400 mesh), unless noted otherwise. The X-ray data were collected at $100(2) \mathrm{K}$ on a Nonius Kappa CCD diffractometer using graphite monochromated MoK $\alpha$ radiation $(\lambda=0.71073 \AA)$ and on an Enraf Nonius MACH3 diffractometer using graphite monochromated CuK $\alpha$ radiation $(\lambda=1.54178 \AA)$.

\subsection{Synthesis and Spectral Data}

\subsubsection{Synthesis of 1-Phenylphosphol-2-ene 1-oxide (1)}

To a $300 \mathrm{~mL}(4.02 \mathrm{~mol})$ of butadiene condensed in a $2 \mathrm{~L}$ round-bottom flask cooled to $-78^{\circ} \mathrm{C}$ was added $2 \mathrm{~g}$ of 2,6-di-tert-butyl-2-methylphenol (polymerization inhibitor) followed by a solution of $136 \mathrm{~mL}(179 \mathrm{~g}, 1 \mathrm{~mol})$ of $P, P$-dichlorophenylphosphine dissolved in $650 \mathrm{~mL}$ of dry petroleum ether. The flask was tightly closed and left at rt for 3 months. After this time, $300 \mathrm{~mL}$ of $\mathrm{H}_{2} \mathrm{O}$ was slowly added to the stirred reaction mixture. Then, $70 \mathrm{~mL}$ of $5 \%$ aqueous solution of $\mathrm{NaHCO}_{3}$ and ca. $160 \mathrm{~mL}$ of $30 \%$ of aqueous solution of $\mathrm{NaOH}$ were gradually added with care to reach the $\mathrm{pH}$ range of 6.5-7.0. Then, the resulting layers were separated and the water layer was washed four times with $\mathrm{CHCl}_{3}(4 \times 100 \mathrm{~mL})$. The combined organic layers were dried over $\mathrm{MgSO}_{4}$, concentrated under reduced pressure and distilled at $167-192^{\circ} \mathrm{C} / 2 \mathrm{mmHg}$ to afford $110 \mathrm{~g}(61.8 \%)$ of 1-phenylphosphol-2-ene 1-oxide (1) which 
solidified after cooling into a white solid: $\mathrm{mp}=79^{\circ} \mathrm{C} .{ }^{1} \mathrm{H}$ NMR $(300 \mathrm{MHz}) \delta 2.05-2.25(\mathrm{~m}, 2 \mathrm{H}), 2.65-2.8$ $(\mathrm{m}, 1 \mathrm{H}), 2.9-3.05(\mathrm{~m}, 1 \mathrm{H}), 6.2-6.4(\mathrm{dm}, 1 \mathrm{H}), 7.0-7.25(\mathrm{dm}, 1 \mathrm{H}), 7.45-7.55(\mathrm{~m}, 3 \mathrm{H}), 7.6-7.75(\mathrm{~m}, 1 \mathrm{H}),{ }^{13} \mathrm{C}$ NMR (75 MHz) $\delta 26.1(\mathrm{~d}, J=71.77), 30.45(\mathrm{~d}, J=10.57), 126.0(\mathrm{~s}), 127.3(\mathrm{~s}), 129(\mathrm{~d}, J=12.09), 130.85$ $(\mathrm{d}, J=10.43), 132.15(\mathrm{~d}, J=2.94), 133.3(\mathrm{~s}), 134.6(\mathrm{~s}), 153.1(\mathrm{~d}, J=24.38),{ }^{31} \mathrm{P}$ NMR $(121 \mathrm{MHz}) \delta 61.2$. Elemental Anal. Calcd. for $\mathrm{C}_{10} \mathrm{H}_{11}$ OP: $\mathrm{C} 67.41, \mathrm{H}$ 6.22, found C 67.3, $\mathrm{H}$ 6.31. This product typically contains a small amount of isomeric 1-phenylphosphol-3-lene 1-oxide (typically less then $3-5 \%$ as revealed by its ${ }^{1} \mathrm{H}$ and ${ }^{31} \mathrm{P}$ NMR spectra by the presence of pertinent signals: ${ }^{1} \mathrm{H}$ NMR $(300 \mathrm{MHz}) \delta 6.0$ $\left(\mathrm{d},{ }^{3} J_{\mathrm{P}-\mathrm{H}}=40 \mathrm{H}\right) ;{ }^{31} \mathrm{P}$ NMR $\left.(121 \mathrm{MHz}) \delta 56.3\right)$. It can be recrystallized from toluene when needed, but, for the purpose of resolution, it has been used as such.

\subsubsection{Resolution of 1-Phenylphosphol-2-ene 1-oxide (1)}

Step 1. Reduction of rac-1.

In a $250 \mathrm{~mL}$ three-neck round-bottom flask equipped with a reflux condenser and an addition funnel was placed $32.5 \mathrm{~g}(0.183 \mathrm{~mol})$ of racemic 1-phenylphosphol-2-ene 1-oxide (1) dissolved in $20 \mathrm{~mL}$ of dry benzene. The solution was degassed, purged with argon, and heated to $60^{\circ} \mathrm{C}$. Then, $25.15 \mathrm{~mL}$ $(0.2 \mathrm{~mol})$ of $\mathrm{PhSiH}_{3}$ dissolved in $20 \mathrm{~mL}$ of benzene was added dropwise over a period of $2 \mathrm{~h}$. After the addition of $\mathrm{PhSiH}_{3}$, the reaction mixture was heated at $60^{\circ} \mathrm{C}$ for additional $40 \mathrm{~h}$. After this time, the reaction mixture was allowed to cool to room temperature, the volatiles were removed under reduced pressure and the residue was distilled under reduced pressure at $80-100{ }^{\circ} \mathrm{C} / 0.8 \mathrm{mmHg}$ to yield $26 \mathrm{~g}$ (88\%) of 1-phenylphosphol-2-ene (2), as a colorless oil which was directly used for preparation of salts in step 2.

Step 2. Quaternization of 1-Phenylphosphol-2-ene (2) by L-menthyl bromoacetate.

In a $2 \mathrm{~L}$ round-bottom flask was dissolved $44.5 \mathrm{~g}(0.16 \mathrm{~mol})$ of L-menthyl bromoacetate in $25 \mathrm{~mL}$ of dry ethanol and $780 \mathrm{~mL}$ of dry ethyl acetate. The solution was degassed and placed under argon atmosphere. Then, $26 \mathrm{~g}(0.16 \mathrm{~mol})$ of rac- 2 dissolved in $40 \mathrm{~mL}$ of ethyl acetate was added dropwise over a period of $8 \mathrm{~h}$ with magnetic stirring. During the addition, after ca. $2 \mathrm{~h}$, a white precipitate started to accumulate slowly. After the addition was completed, the reaction mixture was stirred at room temperature overnight. The formed crystalline precipitate was filtered off and was found to contain the $\left(S_{P}\right)$ epimer of 3 in great predominance $(>90 \%)$. Crystallization of the precipitate from AcOEt-EtOH (10:1) was repeated (1-4 times) until ${ }^{1} \mathrm{H}$ NMR monitoring showed that the resulting crystals contained only a single, diastereomerically pure, salt $\left(S_{P}\right)-3$. The second P-epimer, $\left(R_{P}\right)-3$, was obtained by repeated recrystallizations of the residue from dry benzene-hexane 10:1 (or from toluene), until ${ }^{1} \mathrm{H}$ NMR monitoring showed that the resulting crystals contained only the single, diastereomerically pure, salt $\left(R_{P}\right)-3$ :

$\left(S_{P}\right)$-3: $25.9 \mathrm{~g}(37 \%)$, white crystals: $\mathrm{mp}=197-199{ }^{\circ} \mathrm{C},[\alpha]_{\mathrm{D}}=-13.65$ (c 2.15, $\left.\mathrm{CHCl}_{3}\right) .{ }^{1} \mathrm{H} \mathrm{NMR}$ $(300 \mathrm{MHz}) \delta 0.59(\mathrm{~d}, J=6.9,3 \mathrm{H}), 0.77(\mathrm{~d}, J=6.9,3 \mathrm{H}), 0.83(\mathrm{~d}, J=6.5,3 \mathrm{H}), 0.8-1.0(\mathrm{~m}, 2 \mathrm{H}), 1.2-1.3(\mathrm{~m}$, 1H), 1.3-1.4 (m, 1H), 1.45-1.55 (m, 1H), 1.6-1.7 (m, 2H), 1.7-1.75 (m, 1H), 2.7-2.85 (m, 1H), 3.1-3.2 (m, $1 \mathrm{H}), 3.45-3.6(\mathrm{~m}, 1 \mathrm{H}), 3.75-3.9(\mathrm{~m}, 1 \mathrm{H}), 4.64(\mathrm{dt}, J=4.4, J=10.9,1 \mathrm{H}), 4.67(\mathrm{dd}, J=14.0, J=17.3,1 \mathrm{H}), 4.9$ $(\mathrm{dd}, J=13.5, J=17.3,1 \mathrm{H}), 6.75(\mathrm{dddd}, J=2.2, J=2.3, J=8, J=20.3,1 \mathrm{H}), 7.53$ (dddd, $J=2.6, J=2.7$, $J=8.0, J=36.4,1 \mathrm{H}), 7.55-7.65(\mathrm{~m}, 2 \mathrm{H}), 7.7-7.75(\mathrm{~m}, 1 \mathrm{H}), 7.9-8.1(\mathrm{~m}, 2 \mathrm{H}) ;{ }^{13} \mathrm{C} \mathrm{NMR}(75 \mathrm{MHz}) \delta 15.8$ $(\mathrm{s}), 20.8(\mathrm{~s}), 21.3(\mathrm{~s}), 21.8(\mathrm{~s}), 22.9(\mathrm{~s}), 25.8(\mathrm{~s}), 31.4(\mathrm{~s}), 33.8(\mathrm{~d}, J=34), 33.83(\mathrm{~s}), 34.1(\mathrm{~d}, J=12), 40.5(\mathrm{~s})$, $113.35(\mathrm{~d}, J=81), 120.3(\mathrm{~d}, J=88), 129.95(\mathrm{~d}, J=14), 132.18(\mathrm{~d}, J=11), 134.5(\mathrm{~s}), 162.9(\mathrm{~d}, J=23), 164.93$ $(\mathrm{d}, J=4) ;{ }^{31} \mathrm{P}$ NMR $(121 \mathrm{MHz}) \delta$ 52.91, Elemental Anal. for $\mathrm{C}_{22} \mathrm{H}_{32} \mathrm{BrO}_{2} \mathrm{P}$ : calcd. C 60.14, H 7.34, found C 59.95, H 7.4.

$\left(R_{P}\right)-3: 23.1 \mathrm{~g}(33 \%)$, white tiny needles: $\mathrm{mp}=76-77^{\circ} \mathrm{C},[\alpha]_{\mathrm{D}}=-55.55\left(\right.$ c $\left.2.14, \mathrm{CHCl}_{3}\right) .{ }^{1} \mathrm{H}$ NMR $(300 \mathrm{MHz}) \delta 0.52(\mathrm{~d}, J=6.9,3 \mathrm{H}), 0.78(\mathrm{~d}, J=6.9,3 \mathrm{H}), 0.86(\mathrm{~d}, J=6.3,3 \mathrm{H}), 0.8-1.0(\mathrm{~m}, 2 \mathrm{H}), 1.2-1.3(\mathrm{~m}$, $1 \mathrm{H}), 1.3-1.45(\mathrm{~m}, 1 \mathrm{H}), 1.55-1.55(\mathrm{~m}, 1 \mathrm{H}), 1.6-1.7(\mathrm{~m}, 2 \mathrm{H}), 1.75-1.8(\mathrm{~m}, 1 \mathrm{H}), 2.7-2.85(\mathrm{~m}, 1 \mathrm{H}), 3.1-3.2(\mathrm{~m}$, $1 \mathrm{H}), 3.45-3.55(\mathrm{~m}, 1 \mathrm{H}), 3.8-3.9(\mathrm{~m}, 1 \mathrm{H}), 4.55(\mathrm{dt}, J=4.5, J=11.2,1 \mathrm{H}), 4.8(\mathrm{~d}, J=13.5,2 \mathrm{H}), 6.73(\mathrm{dddd}$, $J=1.8, J=2.1, J=8, J=28,1 \mathrm{H}), 7.58(\mathrm{dddd}, J=2.1, J=2.5, J=8.4, J=37.3,1 \mathrm{H}), 7.6-7.7(\mathrm{~m}, 2 \mathrm{H})$, 
7.7-7.75 (m, 1H), 7.95-8.1 (m, 2H). ${ }^{13} \mathrm{C}$ NMR (75 MHz) $\delta 15.8(\mathrm{~s}), 20.7(\mathrm{~s}), 20.9(\mathrm{~d}, J=57), 21.85(\mathrm{~s}), 22.9$ (s), $25.9(\mathrm{~s}), 31.4(\mathrm{~s}), 33.75(\mathrm{~d}, J=34), 33.83(\mathrm{~s}), 34.09(\mathrm{~d}, J=13), 40.4(\mathrm{~s}), 46.6(\mathrm{~s}), 113.0(\mathrm{~d}, J=80), 120.3$ $(\mathrm{d}, J=84), 129.95(\mathrm{~d}, J=12.5), 132.1(\mathrm{~d}, J=11), 134.6(\mathrm{~s}), 163.1(\mathrm{~d}, J=22), 165.02(\mathrm{~d}, J=4) .{ }^{31} \mathrm{P}$ NMR (121 MHz) $\delta$ 53.03. Elemental Anal. For $\mathrm{C}_{22} \mathrm{H}_{32} \mathrm{BrO}_{2} \mathrm{P}$ : calcd. C 60.14, H 7.34, found C 59.86, H 7.41.

Step 3. Hydrolysis of the resolved phosphonium salts $\left(S_{P}\right)-3$ and $\left(R_{P}\right)-3$.

In a $500 \mathrm{~mL}$ round-bottom flask was dissolved $25 \mathrm{~g}(56.9 \mathrm{mmol})$ of $\left(S_{P}\right)-3$ in $45 \mathrm{~mL}$ of $\mathrm{CH}_{2} \mathrm{Cl}_{2}$. To the solution was added $130 \mathrm{~mL}$ of $\mathrm{H}_{2} \mathrm{O}$ and $120 \mathrm{~mL}$ of $1 \mathrm{M} \mathrm{NaOH}$, and the reaction mixture was stirred at $\mathrm{rt}$ for $12 \mathrm{~h}$. The two phases were separated and the water phase was washed twice with $\mathrm{CH}_{2} \mathrm{Cl}_{2}(2 \times 30 \mathrm{~mL})$. The combined dichloromethane layers were dried over $\mathrm{MgSO}_{4}$ and concentrated. The residue was purified by crystallization from toluene which afforded $9.1 \mathrm{~g}(90 \%)$ of $\left(S_{P}\right)$-1-phenylphosphol-2-ene-1-oxide $\left(S_{P}-1\right)$ as white crystals, $\mathrm{mp}=83-84{ }^{\circ} \mathrm{C},[\alpha]_{\mathrm{D}}=+306.6(\mathrm{c} 1.3$, $\left.\mathrm{CHCl}_{3}\right)$.

The $\left(R_{\mathrm{P}}\right)$-1-phenylphosphol-2-ene-1-oxide $\left(R_{\mathrm{P}}-\mathbf{1}\right)$ was prepared from $\left(R_{\mathrm{P}}\right)$-3 analogously as described for the $S_{\mathrm{P}}$ isomer. White crystals: $\mathrm{mp}=84-85^{\circ} \mathrm{C},[\alpha]_{\mathrm{D}}=-302.4\left(c 1.42, \mathrm{CHCl}_{3}\right)$.

The enantiomeric purity of the synthesized enantiomers of phospholene oxide $\mathbf{1}$ was determined by running their ${ }^{1} \mathrm{H}$ and ${ }^{31} \mathrm{P}$ NMR spectra in the presence of equimolar amounts of (S)-3,5-dinitro- $N$ - $\alpha$-phenylethyl-benzamide as a chiral solvating agent (Kagan's reagent) according to the described procedure [56]. As no presence of signals of the opposite enantiomer could be detected in either spectrum, the enantiomeric purity of both $\left(S_{P}\right)-\mathbf{1}$ and $\left(R_{\mathrm{P}}\right)-\mathbf{1}$ was assigned to be at least $98 \%$ ee.

3.2.3. Synthesis of $\left(S_{\mathrm{P}}\right)-1-$ Phenyl-2,3,3a,4,7,7a-heksahydrophosphindole 1-oxide $\left(S_{\mathrm{P}}-\mathbf{4}\right)$ : Typical Procedure

Two grams (0.011 mol) of $\left(S_{\mathrm{P}}\right)-1,3 \mathrm{~g}(0.056 \mathrm{~mol})$ of 1.3-butadiene, and $0.019 \mathrm{~g}(0.089 \mathrm{mmol})$ of 2,6-di-tert-butyl-4-methylphenol (polymerization inhibitor) dissolved in $7 \mathrm{~mL}$ of toluene were placed in a tightly closed glass ampoule and heated at $200{ }^{\circ} \mathrm{C}$ for $48 \mathrm{~h}$. During that time, two additional portions of the diene were added after controlling the progress of cycloaddition by TLC. After completion of heating, the reaction mixture was dissolved in $75 \mathrm{~mL}$ of methanol and filtered to remove the polymeric side-products formed. Then, $150 \mathrm{~mL}$ of $15 \%$ hydrochloric acid was added and the resulting mixture was washed with benzene $(2 \times 75 \mathrm{~mL})$. The organic layers were combined, dried over anhydrous $\mathrm{MgSO}_{4}$, filtered, and evaporated under reduced pressure. The residue was purified on silica gel column using ethyl acetate/methanol (25:1) as eluent to give a white solid which was recrystallized from toluene/hexane mixture to yield $1.3 \mathrm{~g}(51 \%)$ of cycloadduct $\left(S_{\mathrm{P}}\right)-4$ as white crystals. $\mathrm{Mp}=95-96^{\circ} \mathrm{C}$, $[\alpha]_{\mathrm{D}}=-42.30\left(\mathrm{c} 1.13, \mathrm{CHCl}_{3}\right) .{ }^{1} \mathrm{H}$ NMR $\left(\mathrm{CDCl}_{3}, 300 \mathrm{MHz}\right): \delta 7.80-7.73(\mathrm{~m}, 2 \mathrm{H}) ; 7.52-7.28(\mathrm{~m}, 3 \mathrm{H})$; 5.81-5.70 (m, 2H); 2.52-2.03 (m, 10H). ${ }^{13} \mathrm{C} \mathrm{NMR}\left(\mathrm{CDCl}_{3}, 75.5 \mathrm{MHz}\right): \delta 134.3(\mathrm{~d}, J=88.1 \mathrm{~Hz}) ; 131.5(\mathrm{~d}$, $J=2.8 \mathrm{~Hz}) ; 130.0(\mathrm{~d}, J=9.2 \mathrm{~Hz}) ; 128.5(\mathrm{~d}, J=11.2 \mathrm{~Hz}) ; 124.7(\mathrm{~d}, J=0.9 \mathrm{~Hz}) ; 124.5(\mathrm{~d}, J=6.7 \mathrm{~Hz}) ; 35.7(\mathrm{~d}$, $J=69 \mathrm{~Hz}) ; 34.0(\mathrm{~d}, J=12.2 \mathrm{~Hz}) ; 27.9(\mathrm{~d}, J=5.6 \mathrm{~Hz}) ; 26.7(\mathrm{~d}, J=8.1 \mathrm{~Hz}) ; 25.8(\mathrm{~d}, J=65 \mathrm{~Hz}) ; 19.2(\mathrm{~d}$, $J=3.2 \mathrm{~Hz}) .{ }^{31} \mathrm{P} \mathrm{NMR}\left(\mathrm{CDCl}_{3}, 121.5 \mathrm{MHz}\right): \delta 63.29$ (s). Elemental Anal. for $\mathrm{C}_{14} \mathrm{H}_{17} \mathrm{OP}$ : calcd. $\mathrm{C}, 72.39$; $\mathrm{H}, 7.37$; found $\mathrm{C}, 72.47 ; \mathrm{H}, 7.34$.

\subsubsection{Synthesis of $\left(R_{\mathrm{P}}\right)-1-P h e n y l-2,3,3 \mathrm{a}, 4,7,7 \mathrm{a}-$ heksahydrophosphindole (5): Typical Procedure}

In a Schlenk flask protected from air was placed $1 \mathrm{~g}(0.0043 \mathrm{~mol})$ of $\left(S_{\mathrm{P}}\right)-4$ and $5 \mathrm{~mL}$ of toluene and then $0.7 \mathrm{~g}(0.0064 \mathrm{~mol})$ of $\mathrm{PhSiH}_{3}$ was added. The mixture was heated under argon atmosphere at $75-80{ }^{\circ} \mathrm{C}$ for $24 \mathrm{~h}$. Then, the reaction mixture was concentrated and distilled under reduced pressure to give $0.83 \mathrm{~g}(90 \%)$ of phosphine $\left(R_{\mathrm{P}}\right)-5$ as a colorless oil. $\mathrm{Bp}=160{ }^{\circ} \mathrm{C} / 0.2 \mathrm{mmHg},[\alpha]_{\mathrm{D}}=+75.22(\mathrm{c} 0.9$, $\left.\mathrm{CHCl}_{3}\right) .{ }^{31} \mathrm{P} \mathrm{NMR}\left(\mathrm{CDCl}_{3}, 121.5 \mathrm{MHz}\right): \delta 3.84$ (s). ${ }^{1} \mathrm{H}$ NMR $\left(\mathrm{CDCl}_{3}, 300 \mathrm{MHz}\right): \delta 7.50-7.38(\mathrm{~m}, 2 \mathrm{H})$; 7.34-7.21 (m, 3H); 5.77-5.53 (m, 2H); 2.40-1.97 (m, 9H); 1.74-1.39 (m, 1H). $\left.{ }^{13} \mathrm{C} \mathrm{NMR} \mathrm{(} \mathrm{CDCl}_{3}, 75.5 \mathrm{MHz}\right)$ : $\delta 141.8(\mathrm{~d}, J=23 \mathrm{~Hz}) ; 130.7(\mathrm{~d}, J=15.4 \mathrm{~Hz}) ; 128.3(\mathrm{~d}, J=5.1 \mathrm{~Hz}) ; 127.5(\mathrm{~s}) ; 125.4(\mathrm{~d}, J=13.8 \mathrm{~Hz}) ; 125.4$ $(\mathrm{d}, J=0.9 \mathrm{~Hz}) ; 38.3(\mathrm{~d}, J=8 \mathrm{~Hz}) ; 37.6(\mathrm{~d}, J=2.8 \mathrm{~Hz}) ; 31.4(\mathrm{~d}, J=3.4 \mathrm{~Hz}) ; 26.5(\mathrm{~d}, J=2.4 \mathrm{~Hz}) ; 25.7$ 
$(\mathrm{d}, J=28.6 \mathrm{~Hz}) ; 22.7(\mathrm{~d}, J=14 \mathrm{~Hz})$. The configuration and high enantiomeric purity of $\left(R_{\mathrm{P}}\right)-5$ was confirmed by its oxidation by $\mathrm{H}_{2} \mathrm{O}_{2}$ which afforded back $\left(S_{\mathrm{P}}\right)-4$ of $[\alpha]_{\mathrm{D}}=-42.26\left(c 0.97, \mathrm{CHCl}_{3}\right)$.

3.2.5. Synthesis of $\left(R_{\mathrm{P}}\right)-1$-Phenyl-2,3,3a,4,7,7a-heksahydrophosphindole-borane (6): Typical Procedure

To a solution of $1 \mathrm{~g}(0.0046 \mathrm{~mol})$ of $\left(R_{\mathrm{P}}\right)-5$ in dry THF $(4 \mathrm{~mL})$ kept under argon at $0{ }^{\circ} \mathrm{C}$ was added $0.26 \mathrm{~g}(0.0069 \mathrm{~mol})$ of solid $\mathrm{NaBH}_{4}$ in one portion. Then, $0.46 \mathrm{~g}(0.0077 \mathrm{~mol})$ of acetic acid dissolved in THF $(1.9 \mathrm{~mL})$ was added dropwise within $30 \mathrm{~min}$. The resulting mixture was left at room temperature for $1 \mathrm{~h}$, and the conversion was checked by TLC. Then, water $(4.5 \mathrm{~mL})$ was added slowly, followed by $0.44 \mathrm{~g}(0.42 \mathrm{~mL})$ of acetic acid dissolved in $5.6 \mathrm{~mL}$ of water. The reaction mixture was evaporated and the residue was passed through a silica gel column using $\mathrm{CH}_{2} \mathrm{Cl}_{2}$ hexane (2:3) to give $0.9 \mathrm{~g}(85 \%)$ of borane $\left(R_{\mathrm{P}}\right)-6$ as white crystals. $\mathrm{Mp}=62-63{ }^{\circ} \mathrm{C},[\alpha]_{\mathrm{D}}=-10.46\left(c 1.04, \mathrm{CHCl}_{3}\right) .{ }^{1} \mathrm{H} \mathrm{NMR}\left(\mathrm{CDCl}_{3}\right.$, $300 \mathrm{MHz}): \delta 7.75-7.68(\mathrm{~m}, 2 \mathrm{H}) ; 7.49-7.40(\mathrm{~m}, 3 \mathrm{H}) ; 5.75-5.60(\mathrm{~m}, 2 \mathrm{H}) ; 2.50-1.85(\mathrm{~m}, 10 \mathrm{H}) ; 1.10-0.20(\mathrm{~m}$, $\left.3 \mathrm{H}, \mathrm{BH}_{3}\right) .{ }^{13} \mathrm{C} \mathrm{NMR}\left(\mathrm{CDCl}_{3}, 75.5 \mathrm{MHz}\right): \delta 132(\mathrm{~d}, J=10.1 \mathrm{~Hz}) ; 131.6(\mathrm{~d}, J=8.4 \mathrm{~Hz}) ; 131.2(\mathrm{~d}, J=2.4 \mathrm{~Hz})$; $129.2(\mathrm{~d}, J=9.4 \mathrm{~Hz}) ; 125(\mathrm{~d}, J=8.7 \mathrm{~Hz}) ; 37.4(\mathrm{~d}, J=3.1 \mathrm{~Hz}) ; 35.4(\mathrm{~d}, J=35 \mathrm{~Hz}) ; 30.6 ; 26.7(\mathrm{~d}, J=5.1 \mathrm{~Hz})$; $23.0(\mathrm{~d}, J=35.2 \mathrm{~Hz}) ; 22.1(\mathrm{~d}, J=4.9 \mathrm{~Hz}) .{ }^{31} \mathrm{P} \mathrm{NMR}\left(\mathrm{CDCl}_{3}, 121.5 \mathrm{MHz}\right): \delta 40.11$. Elemental Anal. For $\mathrm{C}_{14} \mathrm{H}_{20}$ BP: calcd. C, 73.08; $\mathrm{H}, 8.76$; found $\mathrm{C}, 72.99 ; \mathrm{H}, 8.36$.

3.2.6. Synthesis of $\left(S_{\mathrm{P}}\right)$-1-Phenyl-2,3,3a,4,7,7a-heksahydrophosphindole 1-sulfide (7): Typical Procedure

To a solution of $1 \mathrm{~g}\left(0.0046\right.$ mole) of phosphine $\left(R_{\mathrm{P}}\right)-5 \mathrm{in} 6 \mathrm{~mL}$ of benzene under argon was added $0.14 \mathrm{~g}(0.0046 \mathrm{~mol})$ of sublimed sulfur. The reaction mixture was stirred at room temperature for $24 \mathrm{~h}$. After this time, the reaction mixture was concentrated and the crude product was purified by column chromatography using $\mathrm{CH}_{2} \mathrm{Cl}_{2}$ /hexane (2:3) followed by crystallization from methanol to yield $1.10 \mathrm{~g}$ $(96 \%)$ of sulfide 7 as white crystals. $\mathrm{Mp}=90-91{ }^{\circ} \mathrm{C},[\alpha]_{\mathrm{D}}=-19.08$ (c 1.13, $\left.\mathrm{CHCl}_{3}\right) .{ }^{1} \mathrm{H} \mathrm{NMR}\left(\mathrm{CDCl}_{3}\right.$, $300 \mathrm{MHz}): \delta$ 7.93-7.85 (m, 2H); 7.55-7.45 (m, 3H); 5.83-5.70 (m, 2H); 2.71-2.62 (m, 1H); 2.50-1.95 (m, 9H). ${ }^{13} \mathrm{C} \mathrm{NMR}\left(\mathrm{CDCl}_{3}, 75.5 \mathrm{MHz}\right): \delta 135$ (d, J = $\left.70.1 \mathrm{~Hz}\right) ; 131.7(\mathrm{~d}, J=3 \mathrm{~Hz}) ; 130.8(\mathrm{~d}, J=9.8 \mathrm{~Hz}) ; 129$ $(\mathrm{d}, J=11.5 \mathrm{~Hz}) ; 125.2(\mathrm{~d}, J=7.6 \mathrm{~Hz}) ; 125.1(\mathrm{~d}, J=1.3 \mathrm{~Hz}) ; 39.0(\mathrm{~d}, J=53 \mathrm{~Hz}) ; 36.3(\mathrm{~d}, J=10.3 \mathrm{~Hz}) ; 32.5$ $(\mathrm{d}, J=52.7 \mathrm{~Hz}) ; 29.9(\mathrm{~d}, J=3.7 \mathrm{~Hz}) ; 27.3(\mathrm{~d}, J=7.2 \mathrm{~Hz}) .{ }^{31} \mathrm{P}$ NMR $\left(\mathrm{CDCl}_{3}, 121.5 \mathrm{MHz}\right): \delta 65.56(\mathrm{~s})$. Elemental Anal. For $\mathrm{C}_{14} \mathrm{H}_{17} \mathrm{SP}$ : calcd. 67.71; $\mathrm{H}, 6.89$; found $\mathrm{C}, 67.57 ; \mathrm{H}, 6.85$.

3.2.7. Synthesis of $\left(S_{\mathrm{P}}\right)-1-P h e n y l-2,3,3 \mathrm{a}, 4,7,7 \mathrm{a}-$ heksahydrophosphindole 1-Selenide (8): Typical Procedure

To a solution of $1 \mathrm{~g}\left(0.0046\right.$ mole) of phosphine $\left(R_{\mathrm{P}}\right)-5 \mathrm{in} 6 \mathrm{~mL}$ of benzene under argon was added $0.36 \mathrm{~g}(0.0046 \mathrm{~mol})$ of selenium. The reaction mixture was magnetically stirred at room temperature for $24 \mathrm{~h}$. After this time, the reaction mixture was concentrated and the crude product was purified by column chromatography using $\mathrm{CH}_{2} \mathrm{Cl}_{2}$ /hexane (2:3) followed by crystallization from methanol to yield $1.25 \mathrm{~g}(92 \%)$ of selenide 8 as white crystals. $\mathrm{Mp}=63^{\circ} \mathrm{C},[\alpha]_{\mathrm{D}}=-15.05\left(\right.$ c $\left.1.65, \mathrm{CHCl}_{3}\right) .{ }^{1} \mathrm{H} \mathrm{NMR}\left(\mathrm{CDCl}_{3}\right.$, $300 \mathrm{MHz}): \delta$ 7.92-7.84 (m, 2H); 7.50-7.45 (m, 3H); 5.82-5.69 (m, 2H); 2.89-2.80 (m, 1H); 2.52-2.04 (m, 9H). ${ }^{13} \mathrm{C} \mathrm{NMR}\left(\mathrm{CDCl}_{3}, 75.5 \mathrm{MHz}\right): \delta 132(\mathrm{~d}, J=70.1 \mathrm{~Hz}) ; 131.7(\mathrm{~d}, J=3 \mathrm{~Hz}) ; 131.1(\mathrm{~d}, J=9.8 \mathrm{~Hz}) ; 129$ $(\mathrm{d}, J=11.5 \mathrm{~Hz}) ; 125.1(\mathrm{~d}, J=8.5 \mathrm{~Hz}) ; 125.0(\mathrm{~d}, J=1.5 \mathrm{~Hz}) ; 38.5(\mathrm{~d}, J=45.8 \mathrm{~Hz}) ; 36.6(\mathrm{~d}, J=9.5 \mathrm{~Hz}) ; 32.9$ $(\mathrm{d}, J=46.3 \mathrm{~Hz}) ; 30.4(\mathrm{~d}, J=2.7 \mathrm{~Hz}) ; 27.2(\mathrm{~d}, J=7.2 \mathrm{~Hz}) ; 23.3 .{ }^{31} \mathrm{P} \mathrm{NMR}\left(\mathrm{CDCl}_{3}, 121.5 \mathrm{MHz}\right): \delta 53.81(\mathrm{~s})$. Elemental Anal. For $\mathrm{C}_{14} \mathrm{H}_{17} \mathrm{SeP}$ : calcd. C, 56.95; H, 5.80; found C, 56.79; H, 5.70.

\subsubsection{Synthesis of $\left(S_{\mathrm{P}}\right)$-1-Phenyl-octahydrophosphindole 1-oxide (9): Typical Procedure}

To a flask containing $1 \mathrm{~g}(0.0043 \mathrm{~mol})$ of $\left(S_{\mathrm{P}}\right)-5$ dissolved in $15 \mathrm{~mL}$ of methanol was added 0.045 $\mathrm{g}(0.00043 \mathrm{~mol})$ of $\mathrm{Pd} / \mathrm{C}$. Argon was passed through the flask for $10 \mathrm{~min}$. , and the flask was capped with a balloon filled with hydrogen. Then, the reaction mixture was magnetically stirred at room temperature for $24 \mathrm{~h}$, filtered through Celite and the filtrate was evaporated. The resulting solid residue was recrystallized from toluene/hexane to give $0.99 \mathrm{~g}(98 \%)$ of saturated oxide $\left(S_{\mathrm{P}}\right)-9$ as white crystals. $\mathrm{Mp}=96-98^{\circ} \mathrm{C},[\alpha]_{\mathrm{D}}=-27.65\left(c 1.34, \mathrm{CHCl}_{3}\right) .{ }^{1} \mathrm{H}$ NMR $\left(\mathrm{CDCl}_{3}, 300 \mathrm{MHz}\right): \delta 7.79-7.71(\mathrm{~m}$, 


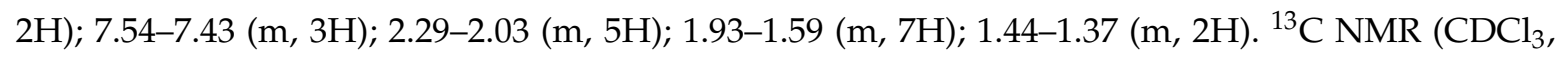
$75.5 \mathrm{MHz}): \delta 135.1(\mathrm{~d}, J=87 \mathrm{~Hz}) ; 131.4(\mathrm{~d}, J=2.8 \mathrm{~Hz}) ; 129.9(\mathrm{~d}, J=9.2 \mathrm{~Hz}) ; 128.5(\mathrm{~d}, J=11.1 \mathrm{~Hz}) ; 39.7$ $(\mathrm{d}, J=68.2 \mathrm{~Hz}) ; 38.2(\mathrm{~d}, J=11.4 \mathrm{~Hz}) ; 28.10(\mathrm{~d}, J=6.8 \mathrm{~Hz}) ; 27.5(\mathrm{~d}, J=64.7 \mathrm{~Hz}) ; 27.2(\mathrm{~d}, J=5.8 \mathrm{~Hz}) ; 24.3$ $(\mathrm{d}, J=6.9 \mathrm{~Hz}) ; 22.6 ; 21.50(\mathrm{~d}, J=3.3 \mathrm{~Hz}) .{ }^{31} \mathrm{P} \mathrm{NMR}\left(\mathrm{CDCl}_{3}, 121.5 \mathrm{MHz}\right): \delta 60.01$ (s). Elemental Anal. For $\mathrm{C}_{14} \mathrm{H}_{19} \mathrm{OP}$ : calcd. C, 71.77; $\mathrm{H}, 8.17$; found $\mathrm{C}, 71.62 ; \mathrm{H}, 8.10$.

3.2.9. Synthesis of $\left(R_{\mathrm{P}}\right)$-1-Phenyl-octahydrophosphindole (10)

$\left(R_{\mathrm{P}}\right)-10$ was obtained in $86 \%$ yield according to typical procedure described in Section 3.2.4. $\left(R_{\mathrm{P}}\right)-10$ : a colorless oil, bp $=136{ }^{\circ} \mathrm{C} / 0.2 \mathrm{mmHg},[\alpha]_{\mathrm{D}}=+26.61\left(c 1.1, \mathrm{CHCl}_{3}\right) .{ }^{1} \mathrm{H} \mathrm{NMR}\left(\mathrm{CDCl}_{3}\right.$, $300 \mathrm{MHz}): \delta 7.50-7.43(\mathrm{~m}, 2 \mathrm{H}) ; 7.36-7.26(\mathrm{~m}, 3 \mathrm{H}) ; 2.32-2.17(\mathrm{~m}, 3 \mathrm{H}) ; 2.05-1.78(\mathrm{~m}, 5 \mathrm{H}) ; 1.60-1.41(\mathrm{~m}$, $6 \mathrm{H}) .{ }^{13} \mathrm{C} \mathrm{NMR}\left(\mathrm{CDCl}_{3}, 75.5 \mathrm{MHz}\right): \delta 135(\mathrm{~d}, J=11.6 \mathrm{~Hz}) ; 131.0(\mathrm{~d}, J=16.5 \mathrm{~Hz}) ; 128.6(\mathrm{~d}, J=5.4 \mathrm{~Hz})$; $127.8(\mathrm{~s}) ; 44.5(\mathrm{~d}, J=8.9 \mathrm{~Hz}) ; 41.4(\mathrm{~d}, J=1.4 \mathrm{~Hz}) ; 31.6(\mathrm{~d}, J=3.1 \mathrm{~Hz}) ; 28.1(\mathrm{~d}, J=2.2 \mathrm{~Hz}) ; 27.8(\mathrm{~d}$, $J=26.1 \mathrm{~Hz}) ; 25.5(\mathrm{~d}, J=13.1 \mathrm{~Hz}) ; 23.8(\mathrm{~d}, J=12.1 \mathrm{~Hz}) ; 23.1 .{ }^{31} \mathrm{P} \mathrm{NMR}\left(\mathrm{CDCl}_{3}, 121.5 \mathrm{MHz}\right): \delta-1.38(\mathrm{~s})$. The configuration and high enantiomeric purity of $\left(R_{\mathrm{P}}\right)-\mathbf{1 0}$ was confirmed by its oxidation by $\mathrm{H}_{2} \mathrm{O}_{2}$ which afforded back $\left(S_{\mathrm{P}}\right)-\mathbf{9}$ of $[\alpha]_{\mathrm{D}}=-27.71\left(c\right.$ 1.1, $\left.\mathrm{CHCl}_{3}\right)$.

3.2.10. Synthesis of $\left(R_{\mathrm{P}}\right)$-1-Phenyl-octahydrophosphindole-borane (11): Typical Procedure

To a solution of $1 \mathrm{~g}(0.0046 \mathrm{~mol})$ of phosphine $\left(R_{\mathrm{P}}\right)-10 \mathrm{in} 6 \mathrm{~mL}$ of benzene under argon atmosphere was added $0.50 \mathrm{~g}(0.0066 \mathrm{~mol})$ of $\mathrm{BH}_{3}-\mathrm{SMe}_{2}$ complex and the reaction mixture was stirred at room temperature for $24 \mathrm{~h}$. At the end of the reaction, the mixture was concentrated and the crude product was passed through a silica gel column using $\mathrm{CH}_{2} \mathrm{Cl}_{2}$ /hexane (2:3) as eluent to give $0.96 \mathrm{~g}(95 \%)$ of phosphine-borane $\left(R_{\mathrm{P}}\right)-\mathbf{1 1}$ white solid. $\mathrm{Mp}=68-69^{\circ} \mathrm{C},[\alpha]_{\mathrm{D}}=-5.04\left(c 1.15, \mathrm{CHCl}_{3}\right) .{ }^{1} \mathrm{H} \mathrm{NMR}\left(\mathrm{CDCl}_{3}\right.$, $300 \mathrm{MHz}): \delta 7.74-7.86(\mathrm{~m}, 2 \mathrm{H}) ; 7.47-7.45(\mathrm{~m}, 3 \mathrm{H}) ; 2.29-1.32(\mathrm{~m}, 14 \mathrm{H}) ; 1.25-0.40\left(\mathrm{~m}, 3 \mathrm{H}, \mathrm{BH}_{3}\right) .{ }^{13} \mathrm{C}$ NMR $\left(\mathrm{CDCl}_{3}, 75.5 \mathrm{MHz}\right): \delta 132.7(\mathrm{~d}, J=46.5 \mathrm{~Hz}) ; 131.6(\mathrm{~d}, J=8.4 \mathrm{~Hz}) ; 131.2(\mathrm{~d}, J=2.5 \mathrm{~Hz}) ; 129.1(\mathrm{~d}$, $J=9.4 \mathrm{~Hz}) ; 40.9(\mathrm{~d}, J=3.0 \mathrm{~Hz}) ; 39.7(\mathrm{~d}, J=33.8 \mathrm{~Hz}) ; 29.5 ; 27.8(\mathrm{~d}, J=5 \mathrm{~Hz}) ; 25.2(\mathrm{~d}, J=10.5 \mathrm{~Hz}) ; 24.3$ $(\mathrm{d}, J=35.7 \mathrm{~Hz}) ; 24.0(\mathrm{~d}, J=3.9 \mathrm{~Hz}) ; 22.3 .{ }^{31} \mathrm{P} \mathrm{NMR}\left(\mathrm{CDCl}_{3}, 121.5 \mathrm{MHz}\right): \delta 37.3$. Elemental Anal. For $\mathrm{C}_{14} \mathrm{H}_{22}$ BP: calcd. C, 72.44; $\mathrm{H}, 9.55$; found $\mathrm{C}, 72.23 ; \mathrm{H}, 9.55$.

\subsubsection{Synthesis of $\left(S_{P}\right)$-1-Phenyl-octahydrophosphindole 1-sulfide (12)}

$\left(S_{\mathrm{P}}\right)$-12 was obtained in 94\% yield according to typical procedure described in Section 3.2.6. $\left(S_{\mathrm{P}}\right)$-12: white crystals, $\mathrm{mp}=82-84{ }^{\circ} \mathrm{C},[\alpha]_{\mathrm{D}}=-4.03\left(\mathrm{c} 1.15, \mathrm{CHCl}_{3}\right) .{ }^{1} \mathrm{H}$ NMR $\left(\mathrm{CDCl}_{3}, 300 \mathrm{MHz}\right): \delta$ 7.94-7.86 (m, 2H); 7.50-7.47 (m, 3H); 2.68-2.59 (m, 1H); 2.42-2.19 (m, 4H); 2.00-1.90 (m, 3H); 1.73-1.65 $(\mathrm{m}, 3 \mathrm{H}) ; 1.51-1.48(\mathrm{~m}, 2 \mathrm{H}) ; 1.35-1.29(\mathrm{~m}, 1 \mathrm{H}) .{ }^{13} \mathrm{C} \mathrm{NMR}\left(\mathrm{CDCl}_{3}, 75.5 \mathrm{MHz}\right): \delta 135.5(\mathrm{~d}, J=69.5 \mathrm{~Hz})$; $131.6(\mathrm{~d}, J=3 \mathrm{~Hz}) ; 130.6(\mathrm{~d}, J=10 \mathrm{~Hz}) ; 129(\mathrm{~d}, J=11.4 \mathrm{~Hz}) ; 41.8(\mathrm{~d}, J=52 \mathrm{~Hz}) ; 39.5(\mathrm{~d}, J=9.9 \mathrm{~Hz}) ;$ $34.7(\mathrm{~d}, J=52.2 \mathrm{~Hz}) ; 28.3(\mathrm{~d}, J=8.2 \mathrm{~Hz}) ; 28.0(\mathrm{~d}, J=3.7 \mathrm{~Hz}) ; 25.1(\mathrm{~d}, J=10.4 \mathrm{~Hz}) ; 23.5(\mathrm{~d}, J=1.6 \mathrm{~Hz})$; 22.0. ${ }^{31} \mathrm{P}$ NMR $\left(\mathrm{CDCl}_{3}, 121.5 \mathrm{MHz}\right): \delta 64,87$ (s). Elemental Anal. For $\mathrm{C}_{14} \mathrm{H}_{19} \mathrm{SP}$ : calcd. C, 67.17; H, 7.65; found $\mathrm{C}, 67.09 ; \mathrm{H}, 7.55$.

\subsubsection{Synthesis of $\left(S_{\mathrm{P}}\right)$-1-Phenyl-octahydrophosphindole 1-selenide (13)}

$\left(S_{\mathrm{P}}\right)-\mathbf{1 3}$ was obtained in $89 \%$ yield according to typical procedure described in Section 3.2.7. $\left(S_{\mathrm{P}}\right)-\mathbf{1 3}$ : white crystals, $\mathrm{mp}=67-68^{\circ} \mathrm{C},[\alpha]_{\mathrm{D}}=-0.95\left(c 0.97, \mathrm{CHCl}_{3}\right) .{ }^{1} \mathrm{H}$ NMR $\left(\mathrm{CDCl}_{3}, 300 \mathrm{MHz}\right): \delta 7.93-7.83$ (m, 2H); 7.49-7.47 (m, 3H); 2.84-2.74 (m, 1H); 2.56-1.35 (m, 13H). $\left.{ }^{13} \mathrm{C} \mathrm{NMR} \mathrm{(CDCl} 3,75,5 \mathrm{MHz}\right): \delta 134.5$ $(\mathrm{d}, J=61.4 \mathrm{~Hz}) ; 131.6(\mathrm{~d}, J=3 \mathrm{~Hz}) ; 131.0(\mathrm{~d}, J=9.8 \mathrm{~Hz}) ; 129.0(\mathrm{~d}, J=11.3 \mathrm{~Hz}) ; 41.3(\mathrm{~d}, J=44.8 \mathrm{~Hz}) ; 39.5$ $(\mathrm{d}, J=8.8 \mathrm{~Hz}) ; 33.9(\mathrm{~d}, J=45.9 \mathrm{~Hz}) ; 28.3(\mathrm{~d}, J=2.8 \mathrm{~Hz}) ; 28.0(\mathrm{~d}, J=8.3 \mathrm{~Hz}) ; 25.3(\mathrm{~d}, J=11.7 \mathrm{~Hz}) ; 25.0$; 21.7. ${ }^{31} \mathrm{P} \mathrm{NMR}\left(\mathrm{CDCl}_{3}, 121.5 \mathrm{MHz}\right): \delta 52.96$ (s). Elemental Anal. For $\mathrm{C}_{14} \mathrm{H}_{19}$ SeP: calcd C, 56.57; H, 6.44; found $\mathrm{C}, 56.40 ; \mathrm{H}, 6.40$. 
3.2.13. Synthesis of $\left(S_{\mathrm{P}}\right)$-3-Phenyl-3-phosphatricyclo[5.2.1.0 2,6]dec-8-ene 3-oxide (14)

$\left(S_{\mathrm{P}}\right)-\mathbf{1 4}$ was obtained in $54 \%$ yield according to typical procedure described in Section 3.2.3. $\left(S_{\mathrm{P}}\right)-14$ : white crystals, $\mathrm{mp}=100-101{ }^{\circ} \mathrm{C},[\alpha]_{\mathrm{D}}=-21.23\left(\mathrm{c} 1.02, \mathrm{CHCl}_{3}\right) .{ }^{1} \mathrm{H} \mathrm{NMR}\left(\mathrm{CDCl}_{3}, 300 \mathrm{MHz}\right): \delta 7.72-7.66$ $(\mathrm{m}, 2 \mathrm{H}) ; 7.49-7.46(\mathrm{~m}, 3 \mathrm{H}) ; 6.64-6.61(\mathrm{~m}, 1 \mathrm{H}) ; 6.25-6.22(\mathrm{~m}, 1 \mathrm{H}) ; 3.32(\mathrm{~s}, 1 \mathrm{H}) ; 3.04(\mathrm{~m}, 2 \mathrm{H}) ; 2.73-2.70$ $(\mathrm{m}, 1 \mathrm{H}) ; 1.96-1.85(\mathrm{~m}, 5 \mathrm{H}) ; 1.58-1.55(\mathrm{~m}, 1 \mathrm{H}) .{ }^{13} \mathrm{C} \mathrm{NMR}\left(\mathrm{CDCl}_{3}, 75.5 \mathrm{MHz}\right): \delta 138.4(\mathrm{~d}, J=4.97 \mathrm{~Hz}) ;$ $135.0(\mathrm{~d}, J=89.1 \mathrm{~Hz}) ; 133.7(\mathrm{~s}) ; 131.5(\mathrm{~d}, J=2.7 \mathrm{~Hz}) ; 129.8(\mathrm{~d}, J=9.1 \mathrm{~Hz}) ; 128.7(\mathrm{~d}, J=11.0 \mathrm{~Hz}) ; 53.0$ $(\mathrm{d}, J=9.6 \mathrm{~Hz}) ; 48.2(\mathrm{~d}, J=2.1 \mathrm{~Hz}) ; 46.4(\mathrm{~d}, J=2.1 \mathrm{~Hz}) ; 45.1(\mathrm{~d}, J=30.8 \mathrm{~Hz}) ; 44.5(\mathrm{~d}, J=32.6 \mathrm{~Hz}) ; 29.4$ $(\mathrm{d}, J=67.3 \mathrm{~Hz}) ; 23.5(\mathrm{~d}, J=9.8 \mathrm{~Hz}) .{ }^{31} \mathrm{P} \mathrm{NMR}\left(\mathrm{CDCl}_{3}, 121.5 \mathrm{MHz}\right): \delta 61.43$ (s). Elemental Anal. for $\mathrm{C}_{15} \mathrm{H}_{17} \mathrm{OP}$ : calcd. $\mathrm{C}, 73.75 ; \mathrm{H}, 7.01$; found $\mathrm{C}, 73.60 ; \mathrm{H}, 6.98$.

3.2.14. Synthesis of $\left(R_{\mathrm{P}}\right)$-3-Phenyl-3-phosphatricyclo[5.2.1.0 2,6]dec-8-ene (15)

$\left(R_{\mathrm{P}}\right)-\mathbf{1 5}$ was obtained in $89 \%$ yield according to typical procedure described in Section 3.2.4. $\left(R_{\mathrm{P}}\right)$-15: a colorless oil, bp $=150{ }^{\circ} \mathrm{C} / 0.2 \mathrm{mmHg},[\alpha]_{\mathrm{D}}=-16.8\left(c 0.9, \mathrm{CHCl}_{3}\right) .{ }^{1} \mathrm{H} \mathrm{NMR}\left(\mathrm{CDCl}_{3}, 300 \mathrm{MHz}\right)$ : 反 7.42-7.37 (m, 2H); 7.34-7.24 (m, 3H); 6.38-6.35 (m, 1H); 6.16-6.13 (m, 1H); 3.18-3.17 (m, 2H); 3.04-3.0 $(\mathrm{m}, 1 \mathrm{H}) ; 2.90(\mathrm{~s}, 1 \mathrm{H}) ; 1.85-1.78(\mathrm{~m}, 4 \mathrm{H}) ; 1.47-1.65(\mathrm{~m}, 2 \mathrm{H}) .{ }^{13} \mathrm{C} \mathrm{NMR}\left(\mathrm{CDCl}_{3}, 75.5 \mathrm{MHz}\right): \delta 141.6(\mathrm{~d}$, $J=19.4 \mathrm{~Hz}) ; 136.7(\mathrm{~d}, J=9.2 \mathrm{~Hz}) ; 135.5(\mathrm{~s}) ; 131.1(\mathrm{~d}, J=15.4 \mathrm{~Hz}) ; 128.3(\mathrm{~d}, J=5.3 \mathrm{~Hz}) ; 127.3(\mathrm{~s}) ; 52.9(\mathrm{~d}$, $J=6.2 \mathrm{~Hz}) ; 51.2(\mathrm{~d}, J=9.1 \mathrm{~Hz}) ; 50.4(\mathrm{~d}, J=3.4 \mathrm{~Hz}) ; 48.5(\mathrm{~s}) ; 47.3(\mathrm{~d}, J=21.3 \mathrm{~Hz}) ; 30.1(\mathrm{~d}, J=4.1 \mathrm{~Hz}) ; 28.8$ $(\mathrm{d}, J=12.3 \mathrm{~Hz}) .{ }^{31} \mathrm{P} \mathrm{NMR}\left(\mathrm{CDCl}_{3}, 121.5 \mathrm{MHz}\right): \delta-6.84$ (s). The configuration and high enantiomeric purity of $\left(R_{\mathrm{P}}\right)-\mathbf{1 5}$ was confirmed by its oxidation by $\mathrm{H}_{2} \mathrm{O}_{2}$ which afforded back $\left(S_{\mathrm{P}}\right)-\mathbf{1 4}$ of $[\alpha]_{\mathrm{D}}=-21.2$ (c 1.21, $\mathrm{CHCl}_{3}$ ).

\subsubsection{Synthesis of $\left(R_{\mathrm{P}}\right)$-3-Phenyl-3-phosphatricyclo[5.2.1.02,6]dec-8-ene-borane (16)}

$\left(R_{\mathrm{P}}\right)$-16: a colorless oil, $[\alpha]_{\mathrm{D}}=-32.1\left(c 1.04, \mathrm{CHCl}_{3}\right) .{ }^{1} \mathrm{H} \mathrm{NMR}\left(\mathrm{CDCl}_{3}, 300 \mathrm{MHz}\right): \delta 7.70-7.62$ (m, 2H); 7.46-7.43 (m, 3H); 6.58-6.55 (m, 1H); 6.19-6.16 (m, 1H); 3.32-3.21 (m, 2H); 3.01-2.95 (m, 2H); $1.92-1.91(\mathrm{~m}, 4 \mathrm{H}) ; 1.6-1.58(\mathrm{~m}, 1 \mathrm{H}) ; 1.56-1.48(\mathrm{~m}, 1 \mathrm{H}) ; 1.01-0.66\left(\mathrm{~m}, 3 \mathrm{H}, \mathrm{BH}_{3}\right) .{ }^{13} \mathrm{C} \mathrm{NMR} \mathrm{CDCl}_{3}$, $75.5 \mathrm{MHz}): \delta 137.8(\mathrm{~d}, J=3.78 \mathrm{~Hz}) ; 134.4(\mathrm{~s}) ; 131.3(\mathrm{~d}, J=7.8 \mathrm{~Hz}) ; 130.6(\mathrm{~d}, J=2.4 \mathrm{~Hz}) ; 128.8(\mathrm{~d}$, $J=9.1 \mathrm{~Hz}) ; 53.3(\mathrm{~d}, J=9.2 \mathrm{~Hz}) ; 48.4(\mathrm{~d}, J=1.9 \mathrm{~Hz}) ; 48.0(\mathrm{~d}, J=1.5 \mathrm{~Hz}) ; 46.6(\mathrm{~d}, J=4.5 \mathrm{~Hz}) ; 46.0(\mathrm{~s}) ;$ $28.1(\mathrm{~d}, J=33.6 \mathrm{~Hz}) ; 27.7(\mathrm{~d}, J=2.2 \mathrm{~Hz}) .{ }^{31} \mathrm{P} \mathrm{NMR}\left(\mathrm{CDCl}_{3}, 121.5 \mathrm{MHz}\right): \delta$ 35.89. Elemental Anal. For $\mathrm{C}_{15} \mathrm{H}_{20} \mathrm{BP}$ : calcd. $\mathrm{C}, 74.41 ; \mathrm{H}, 8.32$; found $\mathrm{C}, 74.31 ; \mathrm{H}, 8.29$.

3.2.16. Synthesis of $\left(S_{P}\right)$-3-Phenyl-3-phosphatricyclo[5.2.1.0 2,6]dec-8-ene 3-sulfide (17)

$\left(S_{\mathrm{P}}\right)-\mathbf{1 7}$ was obtained in 93\% yield according to typical procedure described in Section 3.2.6. $\left(S_{\mathrm{P}}\right)$-17: white crystals, $\mathrm{mp}=103-105{ }^{\circ} \mathrm{C},[\alpha]_{\mathrm{D}}=-33.01\left(\mathrm{c} 1.03, \mathrm{CHCl}_{3}\right) .{ }^{1} \mathrm{H} \mathrm{NMR}\left(\mathrm{CDCl}_{3}, 300 \mathrm{MHz}\right): \delta$ 7.87-7.79 (m, 2H); 7.48-7.47 (m, 3H); 6.81-6.78 (m, 1H); 6.23-6.21 (m, 1H); 3.36 (s, 1H); 3.20-3.14 (m,

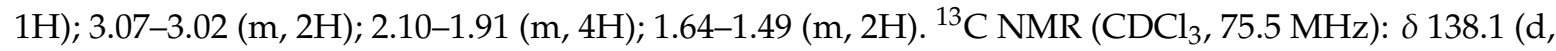
$J=5.1 \mathrm{~Hz}) ; 135.1(\mathrm{~d}, J=71.1 \mathrm{~Hz}) ; 133.75(\mathrm{~s}) ; 131.2(\mathrm{~d}, J=2.85 \mathrm{~Hz}) ; 130.4(\mathrm{~d}, J=9.54 \mathrm{~Hz}) ; 128.7(\mathrm{~d}$, $J=11.2 \mathrm{~Hz}) ; 52.6(\mathrm{~d}, J=10.3 \mathrm{~Hz}) ; 49.5(\mathrm{~d}, J=60.89 \mathrm{~Hz}) ; 47.6(\mathrm{~d}, J=10.8 \mathrm{~Hz}) ; 47.2(\mathrm{~s}) ; 35.7(\mathrm{~d}, J=52.8 \mathrm{~Hz}) ;$ $25.9(\mathrm{~d}, J=6.0 \mathrm{~Hz}) .{ }^{31} \mathrm{P}$ NMR $\left(\mathrm{CDCl}_{3}, 121.5 \mathrm{MHz}\right): \delta 62.19$ (s). Elemental Anal. For $\mathrm{C}_{15} \mathrm{H}_{17} \mathrm{SP}:$ calcd. C, 69.20; H, 6.58; found C, 69.10; H, 6.55.

\subsubsection{Synthesis of $\left(S_{P}\right)$-3-Phenyl-3-phosphatricyclo[5.2.1.0 $\left.{ }^{2,6}\right]$ dec-8-ene 3-selenide (18)}

$\left(S_{\mathrm{P}}\right)-\mathbf{1 7}$ was obtained in $92 \%$ yield according to typical procedure described in Section 3.2.7. (1.2:1) as eluent followed by crystallization from methanol to yield $1.24 \mathrm{~g}(92 \%)$ of selenide $\left(S_{\mathrm{P}}\right)-\mathbf{1 8}$ : white crystals, $\mathrm{mp}=93-94{ }^{\circ} \mathrm{C},[\alpha]_{\mathrm{D}}=-39.98\left(\mathrm{c} 1.09, \mathrm{CHCl}_{3}\right) .{ }^{1} \mathrm{H} \mathrm{NMR}\left(\mathrm{CDCl}_{3}, 300 \mathrm{MHz}\right): \delta 7.87-7.80(\mathrm{~m}$, $2 \mathrm{H}) ; 7.46-7.45(\mathrm{~m}, 3 \mathrm{H}) ; 6.90-6.88(\mathrm{~m}, 1 \mathrm{H}) ; 6.23-6.20(\mathrm{~m}, 1 \mathrm{H}) ; 3.39(\mathrm{~s}, 1 \mathrm{H}) ; 3.25-3.23(\mathrm{~m}, 1 \mathrm{H}) ; 3.22-3.10(\mathrm{~m}$, 2H); 2.21-2.14 (m, 2H); 1.95-1.90 (m, 2H); 1.58-1.52 (m, 2H). ${ }^{13} \mathrm{C} \mathrm{NMR}\left(\mathrm{CDCl}_{3}, 75.5 \mathrm{MHz}\right): \delta 137.7(\mathrm{~d}$, $J=5.3 \mathrm{~Hz}) ; 133.9(\mathrm{~d}, J=63 \mathrm{~Hz}) ; 133.8(\mathrm{~s}) ; 131.3(\mathrm{~d}, J=2.9 \mathrm{~Hz}) ; 130.9(\mathrm{~d}, J=9.5 \mathrm{~Hz}) ; 128.7(\mathrm{~d}, J=11.1 \mathrm{~Hz}) ;$ $52.6(\mathrm{~d}, J=10.5 \mathrm{~Hz}) ; 49.8(\mathrm{~d}, J=53.6 \mathrm{~Hz}) ; 49.4(\mathrm{~d}, J=1.9 \mathrm{~Hz}) ; 48.7(\mathrm{~d}, J=9.2 \mathrm{~Hz}) ; 47.7(\mathrm{~s}) ; 36.1(\mathrm{~d}$, 
$J=45.9 \mathrm{~Hz}) ; 27.1(\mathrm{~d}, J=4.2 \mathrm{~Hz}) .{ }^{31} \mathrm{P} \mathrm{NMR}\left(\mathrm{CDCl}_{3}, 121.5 \mathrm{MHz}\right): \delta 47.22$ (s). Elemental Anal. For $\mathrm{C}_{15} \mathrm{H}_{17} \mathrm{SeP}$ : calcd. C, 58.63; H, 5.57; found C, 58.45; H, 5.53.

3.2.18. Synthesis of $\left(S_{P}\right)$-3-Phenyl-3-phosphatricyclo[5.2.1.0 2,6 $]$ decane 3-oxide (19)

$\left(S_{\mathrm{P}}\right)$-19 was obtained in $98 \%$ yield according to typical procedure described in Section 3.2.8. The resulting solid residue was recrystallized from toluene/hexane to give $0.98 \mathrm{~g}(98 \%)$ of saturated oxide $\left(S_{\mathrm{P}}\right)$-19: white crystals, $\mathrm{mp}=105-106{ }^{\circ} \mathrm{C},[\alpha]_{\mathrm{D}}=-20.57\left(c 1.08, \mathrm{CHCl}_{3}\right) .{ }^{1} \mathrm{H} \mathrm{NMR}\left(\mathrm{CDCl}_{3}, 300 \mathrm{MHz}\right): \delta$ 7.73-7.65 (m, 2H); 7.54-7.43 (m, 3H); 2.79-2.67 (m, 2H); 2.40-2.30 (m, 3H); 2.12-2.00 (m, 3H); 1.85-1.75 $(\mathrm{m}, 2 \mathrm{H}) ; 1.69-1.52(\mathrm{~m}, 5 \mathrm{H}) .{ }^{13} \mathrm{C} \mathrm{NMR}\left(\mathrm{CDCl}_{3}, 75.5 \mathrm{MHz}\right): \delta 135.7(\mathrm{~d}, J=88.9 \mathrm{~Hz}) ; 131.7(\mathrm{~d}, J=2.6 \mathrm{~Hz})$; $129.9(\mathrm{~d}, J=8.9 \mathrm{~Hz}) ; 129.0(\mathrm{~d}, J=10.8 \mathrm{~Hz}) ; 44.2(\mathrm{~d}, J=15.7 \mathrm{~Hz}) ; 43.8(\mathrm{~d}, J=12.0 \mathrm{~Hz}) ; 43.4(\mathrm{~d}, J=2.3 \mathrm{~Hz}) ;$ $42.6(\mathrm{~d}, J=73.6 \mathrm{~Hz}) ; 40.7(\mathrm{~d}, J=2.4 \mathrm{~Hz}) ; 29.4(\mathrm{~d}, J=65.3 \mathrm{~Hz}) ; 25.4(\mathrm{~d}, J=6.2 \mathrm{~Hz}) ; 23.5 ; 21.45(\mathrm{~d}$, $J=10.4 \mathrm{~Hz}) .{ }^{31} \mathrm{P} \mathrm{NMR}\left(\mathrm{CDCl}_{3}, 121.5 \mathrm{MHz}\right): \delta 60.03$ (s). Elemental Anal. For $\mathrm{C}_{15} \mathrm{H}_{19} \mathrm{OP}$ : calcd. C, 73.15; $\mathrm{H}, 7.77$; found $\mathrm{C}, 73.15 ; \mathrm{H}, 7.74$.

3.2.19. Synthesis of $\left(R_{\mathrm{P}}\right)$-3-Phenyl-3-phosphatricyclo[5.2.1.0 2,6$]$ decane (20)

$\left(R_{\mathrm{P}}\right)$-20 was obtained in 87\% yield according to typical procedure described in Section 3.2.4. $\left(R_{\mathrm{P}}\right)$-20: a colorless oil, bp $=210{ }^{\circ} \mathrm{C} / 0.3 \mathrm{mmHg},[\alpha]_{\mathrm{D}}=-11.62\left(c \quad 0.9, \mathrm{CHCl}_{3}\right) .{ }^{1} \mathrm{H} \mathrm{NMR}\left(\mathrm{CDCl}_{3}\right.$, $300 \mathrm{MHz}): \delta 7.62-7.12(\mathrm{~m}, 5 \mathrm{H}) ; 2.78-2.67(\mathrm{~m}, 2 \mathrm{H}) ; 2.44(\mathrm{~s}, 1 \mathrm{H}) ; 2.16(\mathrm{~s}, 1 \mathrm{H}) ; 1.99-1.82(\mathrm{~m}, 2 \mathrm{H}) ; 1.77-1.67$ $(\mathrm{m}, 2 \mathrm{H}) ; 1.52-1.44(\mathrm{~m}, 2 \mathrm{H}) ; 1.40-1.18(\mathrm{~m}, 4 \mathrm{H}) .{ }^{13} \mathrm{C} \mathrm{NMR}\left(\mathrm{CDCl}_{3}, 75.5 \mathrm{MHz}\right): \delta 142.0(\mathrm{~d}, J=16.2 \mathrm{~Hz})$; $131.4(\mathrm{~d}, J=15.46 \mathrm{~Hz}) ; 128.6(\mathrm{~d}, J=5.4 \mathrm{~Hz}) ; 127.69(\mathrm{~s}) ; 50.8(\mathrm{~d}, J=10.6 \mathrm{~Hz}) ; 48.9(\mathrm{~d}, J=4.1 \mathrm{~Hz}) ; 43.6(\mathrm{~d}$, $J=6.5 \mathrm{~Hz}) ; 43.4(\mathrm{~s}) ; 42.1(\mathrm{~d}, J=18.1 \mathrm{~Hz}) ; 29.2(\mathrm{~d}, J=12.5 \mathrm{~Hz}) ; 28.7(\mathrm{~d}, J=4.9 \mathrm{~Hz}) ; 25.7(\mathrm{~d}, J=17.7 \mathrm{~Hz}) ;$ 23.9 (s). ${ }^{31} \mathrm{P} \mathrm{NMR}\left(\mathrm{CDCl}_{3}, 121.5 \mathrm{MHz}\right): \delta-9.90$ (s). The configuration and high enantiomeric purity of $\left(R_{\mathrm{P}}\right)-20$ was confirmed by its oxidation by $\mathrm{H}_{2} \mathrm{O}_{2}$ which afforded back $\left(S_{\mathrm{P}}\right)-19$ of $[\alpha]_{\mathrm{D}}=-20.52(c 1.2$, $\left.\mathrm{CHCl}_{3}\right)$.

3.2.20. Synthesis of $\left(R_{\mathrm{P}}\right)$-3-Phenyl-3-phosphatricyclo[5.2.1.0 $0^{2,6}$ ]decane-borane (21)

To a solution of $1 \mathrm{~g}(0.004 \mathrm{~mol})$ of phosphine $\left(\boldsymbol{R}_{\mathbf{P}}\right)-20$ in $6 \mathrm{~mL}$ of benzene under argon atmosphere was added $0.49 \mathrm{~g}(0.0065 \mathrm{~mol})$ of the $\mathrm{BH}_{3}-\mathrm{SMe}_{2}$ complex, and the reaction mixture was stirred at room temperature for $24 \mathrm{~h}$. At the end of the reaction, the mixture was concentrated and the crude product was passed through a silica gel column using $\mathrm{CH}_{2} \mathrm{Cl}_{2}$ /hexane (1:2) as eluent to yield $0.95 \mathrm{~g}(90 \%)$ of phosphine-borane $\left(\boldsymbol{R}_{\mathbf{P}}\right)-21$ as an oil. $[\alpha]_{\mathrm{D}}=-42.24\left(c 0.98, \mathrm{CHCl}_{3}\right) \cdot{ }^{1} \mathrm{H} \mathrm{NMR}\left(\mathrm{CDCl}_{3}, 300 \mathrm{MHz}\right): \delta$ 7.65-7.55 (m, 2H); 7.47-7.37 (m, 3H); 2.92-2.84 (m, 1H); 2.72-2.66 (m, 2H); $2.36(\mathrm{~s}, 1 \mathrm{H}) ; 2.15-1.95(\mathrm{~m}$, $5 \mathrm{H}) ; 1.58-1.36(\mathrm{~m}, 5 \mathrm{H}) ; 1.25-0.30\left(\mathrm{~m}, 3 \mathrm{H}, \mathrm{BH}_{3}\right) .{ }^{13} \mathrm{C} \mathrm{NMR}\left(\mathrm{CDCl}_{3}, 75.5 \mathrm{MHz}\right): \delta 132(\mathrm{~d}, J=49.1 \mathrm{~Hz})$; $131.3(\mathrm{~d}, J=7.8 \mathrm{~Hz}) ; 130.9(\mathrm{~d}, J=2.3 \mathrm{~Hz}) ; 129.1(\mathrm{~d}, J=9.2 \mathrm{~Hz}) ; 47.3(\mathrm{~d}, J=2.6 \mathrm{~Hz}) ; 45.1(\mathrm{~d}, J=35.7 \mathrm{~Hz}) ;$ $43.8(\mathrm{~d}, J=10.8 \mathrm{~Hz}) ; 43.1(\mathrm{~d}, J=1.4 \mathrm{~Hz}) ; 40.8(\mathrm{~d}, J=3.7 \mathrm{~Hz}) ; 28.2(\mathrm{~d}, J=32.3 \mathrm{~Hz}) ; 25.9(\mathrm{~d}, J=2.0 \mathrm{~Hz})$; $25.3(\mathrm{~d}, J=6.0 \mathrm{~Hz}) ; 23.3(\mathrm{~s}) .{ }^{31} \mathrm{P} \mathrm{NMR}\left(\mathrm{CDCl}_{3}, 121.5 \mathrm{MHz}\right): \delta 33.16$. Elemental Anal. For $\mathrm{C}_{15} \mathrm{H}_{22} \mathrm{BP}$ : calcd. C, 73.80; H, 9.08; found C, 73.70; H, 9.01.

\subsubsection{Synthesis of $\left(S_{\mathrm{P}}\right)$-3-Phenyl-3-phosphatricyclo[5.2.1.0 2,6 $]$ decane 3-sulfide (22)}

$\left(S_{\mathrm{P}}\right)$-22 was obtained in $82 \%$ yield according to typical procedure described in Section 3.2.6. $\left(S_{\mathrm{P}}\right)$-22: white crystals, $\mathrm{mp}=95-96^{\circ} \mathrm{C},[\alpha]_{\mathrm{D}}=-22.61\left(\mathrm{c} 1.72, \mathrm{CHCl}_{3}\right) .{ }^{1} \mathrm{H} \mathrm{NMR}\left(\mathrm{CDCl}_{3}, 300 \mathrm{MHz}\right)$ : $\delta$ 7.82-7.75 (m, 2H); 7.50-7.42 (m, 3H); 2.85-2.74 (m, 2H); 2.70-2.65 (m, 1H); 2.56-2.53 (m, 1H); 2.44 $(\mathrm{s}, 1 \mathrm{H}) ; 2.31-2.22(\mathrm{~m}, 1 \mathrm{H}) ; 2.19-2.07(\mathrm{~m}, 2 \mathrm{H}) ; 1.95-1.79(\mathrm{~m}, 1 \mathrm{H}) ; 1.66-1.46(\mathrm{~m}, 5 \mathrm{H}) .{ }^{13} \mathrm{C} \mathrm{NMR}\left(\mathrm{CDCl}_{3}\right.$, $75.5 \mathrm{MHz}): \delta 135.2(\mathrm{~d}, J=72.2 \mathrm{~Hz}) ; 131.5(\mathrm{~d}, J=2.9 \mathrm{~Hz}) ; 130.3(\mathrm{~d}, J=9.5 \mathrm{~Hz}) ; 129.0(\mathrm{~d}, J=11.2 \mathrm{~Hz}) ;$ $46.3(\mathrm{~d}, J=48.6 \mathrm{~Hz}) ; 45.9(\mathrm{~d}, J=3.8 \mathrm{~Hz}) ; 44.1(\mathrm{~d}, J=2.1 \mathrm{~Hz}) ; 43.4(\mathrm{~d}, J=12.9 \mathrm{~Hz}) ; 41.3(\mathrm{~s}) ; 35.6(\mathrm{~d}$, $J=51.0 \mathrm{~Hz}) ; 24.9(\mathrm{~d}, J=6.7 \mathrm{~Hz}) ; 23.9(\mathrm{~d}, J=6.6 \mathrm{~Hz}) ; 23.4(\mathrm{~s}) .{ }^{31} \mathrm{P} \mathrm{NMR}\left(\mathrm{CDCl}_{3}, 121.5 \mathrm{MHz}\right): \delta 59.32(\mathrm{~s})$. Elemental Anal. For $\mathrm{C}_{15} \mathrm{H}_{19} \mathrm{SP}$ : calcd. C, 68.67; H, 7.30; found C, 68.57; H, 7.27. 
3.2.22. Synthesis of $\left(S_{\mathrm{P}}\right)$-3-Phenyl-3-phosphatricyclo[5.2.1.0 $0^{2,6}$ ]decane 3-selenide (23)

$\left(S_{\mathrm{P}}\right)-23$ was obtained in $90 \%$ yield according to typical procedure described in Section 3.2.7. $\left(S_{\mathrm{P}}\right)$-23: white crystals, $\mathrm{mp}=118-119^{\circ} \mathrm{C},[\alpha]_{\mathrm{D}}=-45.87\left(\mathrm{c} 1.09, \mathrm{CHCl}_{3}\right) .{ }^{1} \mathrm{H} \mathrm{NMR}\left(\mathrm{CDCl}_{3}, 300 \mathrm{MHz}\right): \delta$ 7.82-7.75 (m, 2H); 7.45-7.42 (m, 3H); 2.78-2.76 (m, 3H); 2.61-2.56 (m, 2H); 2.51-2.38 (m, 1H); 2.26-1.92 $(\mathrm{m}, 2 \mathrm{H}) ; 1.82-1.75(\mathrm{~m}, 1 \mathrm{H}) ; 1.61-1.53(\mathrm{~m}, 5 \mathrm{H}) .{ }^{13} \mathrm{C} \mathrm{NMR}\left(\mathrm{CDCl}_{3}, 75.5 \mathrm{MHz}\right): \delta 133.9(\mathrm{~d}, J=64.4 \mathrm{~Hz}) ;$ $131.6(\mathrm{~d}, J=2.9 \mathrm{~Hz}) ; 130.7(\mathrm{~d}, J=9.5 \mathrm{~Hz}) ; 129.0(\mathrm{~d}, J=11.1 \mathrm{~Hz}) ; 46.5(\mathrm{~d}, J=12.7 \mathrm{~Hz}) ; 46.1(\mathrm{~d}, J=26.1 \mathrm{~Hz}) ;$ $44.3(\mathrm{~d}, J=2.0 \mathrm{~Hz}) ; 43.4(\mathrm{~d}, J=13.0 \mathrm{~Hz}) ; 41.7(\mathrm{~s}) ; 36.1(\mathrm{~d}, J=44.4 \mathrm{~Hz}) ; 25.1(\mathrm{~d}, J=4.7 \mathrm{~Hz}) ; 24.6(\mathrm{~d}$, $J=7.0 \mathrm{~Hz}$ ); 23.4 (s). ${ }^{31} \mathrm{P}$ NMR $\left(\mathrm{CDCl}_{3}, 121.5 \mathrm{MHz}\right): \delta 42.60$ (s). Elemental Anal. For $\mathrm{C}_{15} \mathrm{H}_{19} \mathrm{SeP}$ : calcd. C, 58.25; H, 6.19; found C, 58.11; H, 6.15.

\subsubsection{Synthesis of $\left(S_{P}\right)$-3-Phenyl-3-phosphatricyclo[5.2.2.0 2,6$]$ undec-8-ene 3-oxide (24)}

$\left(S_{\mathrm{P}}\right)$-24 was obtained in $83 \%$ yield according to typical procedure described for $\left(S_{\mathrm{P}}\right)-\mathbf{4}$ in Section 3.2.3 This time, however, addition of cyclohexadiene was repeated three times $(4+2+1$ equiv. $)$ and the reaction mixture was heated for $72 \mathrm{~h}$. $\left(S_{\mathrm{P}}\right)$-24: white crystals, $\mathrm{mp}=88-89^{\circ} \mathrm{C},[\alpha]_{\mathrm{D}}=-18.3(\mathrm{c} 1.12$, $\left.\mathrm{CHCl}_{3}\right) .{ }^{31} \mathrm{P} \mathrm{NMR}\left(\mathrm{CDCl}_{3}, 121.5 \mathrm{MHz}\right): \delta 61.45$ (s). ${ }^{1} \mathrm{H}$ NMR $\left(\mathrm{CDCl}_{3}, 300 \mathrm{MHz}\right): \delta 7.75-7.68(\mathrm{~m}, 2 \mathrm{H})$; 7.51-7.43 (m, 3H); $6.56(\mathrm{ddd}, 1 \mathrm{H}, J=1.1 \mathrm{~Hz} ; 6.6 \mathrm{~Hz} ; 18 \mathrm{~Hz}) ; 6.28(\mathrm{t}, 1 \mathrm{H}, J=7.4 \mathrm{~Hz}) ; 3.02(\mathrm{~s}, 1 \mathrm{H}) ; 2.71-2.69$ $(\mathrm{m}, 1 \mathrm{H}) ; 2.58-2.49(\mathrm{~m}, 1 \mathrm{H}) ; 2.29(\mathrm{dt}, 1 \mathrm{H}, J=2.5 \mathrm{~Hz} ; 10.2 \mathrm{~Hz}) ; 2.08-1.88(\mathrm{~m}, 4 \mathrm{H}) ; 1.54-1.49(\mathrm{~m}, 2 \mathrm{H})$; 1.36-1.31 (m, 2H). $\left.{ }^{13} \mathrm{C} \mathrm{NMR} \mathrm{(} \mathrm{CDCl}_{3}, 75.5 \mathrm{MHz}\right): \delta 135.6(\mathrm{~d}, J=2.3 \mathrm{~Hz}) ; 134.8(\mathrm{~d}, J=87.2 \mathrm{~Hz}) ; 132.4$; $131.9(\mathrm{~d}, J=2.8 \mathrm{~Hz}) ; 130.5(\mathrm{~d}, J=9 \mathrm{~Hz}) ; 129.0(\mathrm{~d}, J=10.9 \mathrm{~Hz}) ; 44.7(\mathrm{~d}, J=25.6 \mathrm{~Hz}) ; 44.2(\mathrm{~d}, J=36.5 \mathrm{~Hz}) ;$ $35.9(\mathrm{~d}, J=2.1 \mathrm{~Hz}) ; 30.4(\mathrm{~d}, J=2.8 \mathrm{~Hz}) ; 28.7(\mathrm{~d}, J=48.3 \mathrm{~Hz}) ; 28.2(\mathrm{~d}, J=5.4 \mathrm{~Hz}) ; 26.3(\mathrm{~d}, J=12.3 \mathrm{~Hz})$; 25.1. Elemental Anal. For $\mathrm{C}_{16} \mathrm{H}_{19} \mathrm{OP}$ : calcd. C, 74.40; H, 7.41; found $\mathrm{C}, 74.25 ; \mathrm{H}, 7.38$.

\subsubsection{Synthesis of $\left(R_{\mathrm{P}}\right)$-3-Phenyl-3-phosphatricyclo[5.2.2.02,6] undec-8-ene (25)}

$\left(R_{\mathrm{P}}\right)-25$ was obtained in $89 \%$ yield according to typical procedure described in Section 3.2.4. $\left(R_{\mathrm{P}}\right)$-25: a colorless oil, bp $=150{ }^{\circ} \mathrm{C} / 0.2 \mathrm{mmHg},[\alpha]_{\mathrm{D}}=-3.6\left(c 1.67, \mathrm{CHCl}_{3}\right) .{ }^{1} \mathrm{H} \mathrm{NMR}\left(\mathrm{CDCl}_{3}, 300 \mathrm{MHz}\right)$ : $\delta$ 7.39-7.34 (m, 2H); 7.31-7.18 (m, 3H); 6.38-6.26 (m, 2H); 2.97-2.94 (m, 1H); 2.61-2.48 (m, 3H); 2.05-1.96

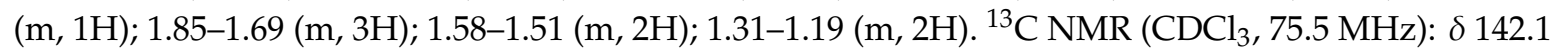
$(\mathrm{d}, J=21.2 \mathrm{~Hz}) ; 135.0 ; 134.2(\mathrm{~d}, J=4.4 \mathrm{~Hz}) ; 130.8(\mathrm{~d}, J=15.1 \mathrm{~Hz}) ; 128.2(\mathrm{~d}, J=5.1 \mathrm{~Hz}) ; 127.4 ; 50.0$ $(\mathrm{d}, J=8.3 \mathrm{~Hz}) ; 47.3(\mathrm{~d}, J=2.9 \mathrm{~Hz}) ; 36.8(\mathrm{~s}) ; 35.3(\mathrm{~d}, J=26.4 \mathrm{~Hz}) ; 35.0(\mathrm{~s}) ; 26.6(\mathrm{~d}, J=10.1 \mathrm{~Hz}) ; 26.0$ $(\mathrm{d}, J=12.9 \mathrm{~Hz}) .{ }^{31} \mathrm{P}$ NMR $\left(\mathrm{CDCl}_{3}, 121.5 \mathrm{MHz}\right): \delta 7.88$. The configuration and high enantiomeric purity of $\left(R_{\mathrm{P}}\right)-25$ was confirmed by its oxidation by $\mathrm{H}_{2} \mathrm{O}_{2}$ which afforded back $\left(S_{\mathrm{P}}\right)-\mathbf{2 4}$ of $[\alpha]_{\mathrm{D}}=-18.35$ (c $0.97, \mathrm{CHCl}_{3}$ ).

\subsubsection{Synthesis of $\left(R_{\mathrm{P}}\right)$-3-Phenyl-3-phosphatricyclo[5.2.2.02,6] undec-8-ene-borane (26)}

$\left(R_{\mathrm{P}}\right)$-26 was obtained in 87\% yield according to typical procedure described in Section 3.2.5. $\left(R_{\mathrm{P}}\right)$-26: white crystals, $\mathrm{mp}=90-91{ }^{\circ} \mathrm{C},[\alpha]_{\mathrm{D}}=-31.98\left(c 1, \mathrm{CHCl}_{3}\right) .{ }^{1} \mathrm{H}$ NMR $\left(\mathrm{CDCl}_{3}, 300 \mathrm{MHz}\right): \delta$ 7.68-7.63 (m, 2H); 7.46-7.44 (m, 3H); 6.48-6.44 (m, 1H); 6.26-6.21 (m, 1H); 3.05-3.03 (m, 1H); 2.68-2.51 $(\mathrm{m}, 3 \mathrm{H}) ; 2.13-2.06(\mathrm{~m}, 1 \mathrm{H}) ; 1.94-1.88(\mathrm{~m}, 3 \mathrm{H}) ; 1.57-1.54(\mathrm{~m}, 2 \mathrm{H}) ; 1.33-1.29(\mathrm{~m}, 2 \mathrm{H}) ; 1.10-0.25(\mathrm{~m}, 3 \mathrm{H}$, $\left.\mathrm{BH}_{3}\right) .{ }^{13} \mathrm{C} \mathrm{NMR}\left(\mathrm{CDCl}_{3}, 75.5 \mathrm{MHz}\right): \delta 135.4(\mathrm{~d}, J=1.49 \mathrm{~Hz}) ; 132.8(\mathrm{~s}) ; 132.3(\mathrm{~d}, J=46.5 \mathrm{~Hz}) ; 131.7(\mathrm{~d}$, $J=8.0 \mathrm{~Hz}) ; 131.1(\mathrm{~d}, J=2.4 \mathrm{~Hz}) ; 129.1(\mathrm{~d}, J=9.1 \mathrm{~Hz}) ; 47.0(\mathrm{~s}) ; 44.5(\mathrm{~d}, J=35.9 \mathrm{~Hz}) ; 36.3(\mathrm{~s}) ; 32.2(\mathrm{~d}$, $J=3.0 \mathrm{~Hz}) ; 32.0(\mathrm{~d}, J=4.7 \mathrm{~Hz}) ; 26.8(\mathrm{~d}, J=12.4 \mathrm{~Hz}) ; 26.4(\mathrm{~d}, J=35.1 \mathrm{~Hz}) ; 25.1(\mathrm{~s}) .{ }^{31} \mathrm{P} \mathrm{NMR}\left(\mathrm{CDCl}_{3}\right.$, $121.5 \mathrm{MHz}$ ): $\delta$ 44.11. Elemental Anal. for $\mathrm{C}_{16} \mathrm{H}_{22} \mathrm{BP}$ : calcd. $\mathrm{C}, 75.03 ; \mathrm{H}, 8.65$; found $\mathrm{C}, 74.92 ; \mathrm{H}, 8.61$.

3.2.26. Synthesis of $\left(S_{\mathrm{P}}\right)$-3-Phenyl-3-phosphatricyclo[5.2.2.02,6] undec-8-ene 3-sulfide (27)

$\left(S_{\mathrm{P}}\right)$-27 was obtained in 96\% yield according to typical procedure described in Section 3.2.6. $\left(S_{\mathrm{P}}\right)-27$ : white crystals, $\mathrm{mp}=13-131^{\circ} \mathrm{C},[\alpha]_{\mathrm{D}}=+6.36\left(c\right.$ 1.03, $\left.\mathrm{CHCl}_{3}\right) .{ }^{1} \mathrm{H} \mathrm{NMR}\left(\mathrm{CDCl}_{3}, 300 \mathrm{MHz}\right)$ : $\delta 7.88-7.79(\mathrm{~m}, 2 \mathrm{H}) ; 7.51-7.42(\mathrm{~m}, 3 \mathrm{H}) ; 6.58(\mathrm{t}, 1 \mathrm{H}, J=7.2 \mathrm{~Hz}) ; 6.25(\mathrm{t}, 1 \mathrm{H}, J=7.2 \mathrm{~Hz}) ; 3.13(\mathrm{~m}, 1 \mathrm{H})$; $2.71-2.65(\mathrm{~m}, 2 \mathrm{H}) ; 2.59-2.54(\mathrm{~m}, 1 \mathrm{H}) ; 2.17-1.87(\mathrm{~m}, 4 \mathrm{H}) ; 1.57-1.47(\mathrm{~m}, 2 \mathrm{H}) ; 1.36-1.30(\mathrm{~m}, 2 \mathrm{H}) .{ }^{13} \mathrm{C}$ NMR $\left(\mathrm{CDCl}_{3}, 75.5 \mathrm{MHz}\right): \delta 135.0(\mathrm{~d}, J=2.4 \mathrm{~Hz}) ; 134.5(\mathrm{~d}, J=78.1 \mathrm{~Hz}) ; 131.8(\mathrm{~s}) ; 131.2(\mathrm{~d}, J=2.9 \mathrm{~Hz}) ; 130.4(\mathrm{~d}$, 
$J=9.6 \mathrm{~Hz}) ; 128.6(\mathrm{~d}, J=11.2 \mathrm{~Hz}) ; 47.19(\mathrm{~d}, J=54.8 \mathrm{~Hz}) ; 46.2(\mathrm{~d}, J=6.4 \mathrm{~Hz}) ; 36.4(\mathrm{~d}, J=1.9 \mathrm{~Hz}) ; 34.0(\mathrm{~d}$, $J=52.7 \mathrm{~Hz}) ; 31.6(\mathrm{~s}) ; 29.6(\mathrm{~d}, J=10.6 \mathrm{~Hz}) ; 25.8(\mathrm{~d}, J=13.5 \mathrm{~Hz}) ; 24.6(\mathrm{~d}, J=1.1 \mathrm{~Hz}) .{ }^{31} \mathrm{P} \mathrm{NMR}\left(\mathrm{CDCl}_{3}\right.$, 121.5 MHz): $\delta 67.98$ (s). Elemental Anal. For $\mathrm{C}_{16} \mathrm{H}_{19} \mathrm{SP}$ : calcd. $\mathrm{C}, 70.04 ; \mathrm{H}, 6.97$; found $\mathrm{C}, 69.95 ; \mathrm{H}, 6.95$.

3.2.27. Synthesis of $\left(S_{\mathrm{P}}\right)$-3-Phenyl-3-phosphatricyclo[5.2.2.0 $\left.{ }^{2,6}\right]$ undec-8-ene 3-selenide (28)

$\left(S_{\mathrm{P}}\right)$-28 was obtained in $92 \%$ yield according to typical procedure described in Section 3.2.7. $\left(S_{\mathrm{P}}\right)$-28: white crystals, $\mathrm{mp}=130-131^{\circ} \mathrm{C},[\alpha]_{\mathrm{D}}=+8.2\left(c 1.09, \mathrm{CHCl}_{3}\right) .{ }^{1} \mathrm{H} \mathrm{NMR}\left(\mathrm{CDCl}_{3}, 300 \mathrm{MHz}\right)$ : $\delta 7.88-7.79(\mathrm{~m}, 2 \mathrm{H}) ; 7.51-7.42(\mathrm{~m}, 3 \mathrm{H}) ; 6.58(\mathrm{t}, 1 \mathrm{H}, J=7.2 \mathrm{~Hz}) ; 6.25(\mathrm{t}, 1 \mathrm{H}, J=7.2 \mathrm{~Hz}) ; 3.13(\mathrm{~m}, 1 \mathrm{H})$; 2.71-2.65 (m, 2H); 2.59-2.54 (m, 1H); 2.17-1.87 (m, 4H); 1.57-1.47 (m, 2H); 1.36-1.30 (m, 2H). ${ }^{13} \mathrm{C} \mathrm{NMR}$ $\left(\mathrm{CDCl}_{3}, 75.5 \mathrm{MHz}\right): \delta 135.0(\mathrm{~d}, J=2.4 \mathrm{~Hz}) ; 134.5(\mathrm{~d}, J=78.1 \mathrm{~Hz}) ; 131.8(\mathrm{~s}) ; 131.2(\mathrm{~d}, J=2.9 \mathrm{~Hz}) ; 130.4(\mathrm{~d}$, $J=9.6 \mathrm{~Hz}) ; 128.6(\mathrm{~d}, J=11.2 \mathrm{~Hz}) ; 47.19(\mathrm{~d}, J=54.8 \mathrm{~Hz}) ; 46.2(\mathrm{~d}, J=6.4 \mathrm{~Hz}) ; 36.4(\mathrm{~d}, J=1.9 \mathrm{~Hz}) ; 34.0(\mathrm{~d}$, $J=52.7 \mathrm{~Hz}) ; 31.6(\mathrm{~s}) ; 29.6(\mathrm{~d}, J=10.6 \mathrm{~Hz}) ; 25.8(\mathrm{~d}, J=13.5 \mathrm{~Hz}) ; 24.6(\mathrm{~d}, J=1.1 \mathrm{~Hz}) .{ }^{31} \mathrm{P} \mathrm{NMR}\left(\mathrm{CDCl}_{3}\right.$, 121.5 MHz): $\delta 59.8$ (s). Elemental Anal. For $\mathrm{C}_{16} \mathrm{H}_{19} \mathrm{SeP}$ : calcd. $\mathrm{C}, 59.82 ; \mathrm{H}, 5.96$; found $\mathrm{C}, 59.75 ; \mathrm{H}, 5.94$.

3.2.28. Synthesis of $\left(S_{\mathrm{P}}\right)$-3-Phenyl-3-phosphatricyclo[5.2.2.0 2,6] undecane 3-oxide (29)

$\left(S_{\mathrm{P}}\right)$-29 was obtained in 98\% yield according to typical procedure described in Section 3.2.8. $\left(S_{\mathrm{P}}\right)$-29: white crystals, $\mathrm{mp}=119-120{ }^{\circ} \mathrm{C},[\alpha]_{\mathrm{D}}=-5.6\left(c 1.08, \mathrm{CHCl}_{3}\right) .{ }^{1} \mathrm{H}$ NMR $\left(\mathrm{CDCl}_{3}, 300 \mathrm{MHz}\right): \delta$ 7.77-7.70 (m, 2H); 7.54-7.45 (m, 3H); 2.33-2.00 (m, 7H); 1.95-1.82 (m, 2H); 1.79-1.63 (m, 3H); 1.56-1.46 $(\mathrm{m}, 4 \mathrm{H}) .{ }^{13} \mathrm{C} \mathrm{NMR}\left(\mathrm{CDCl}_{3}, 75,5 \mathrm{MHz}\right): \delta 134.9(\mathrm{~d}, J=87.4 \mathrm{~Hz}) ; 131.8(\mathrm{~d}, J=2.6 \mathrm{~Hz}) ; 130.4(\mathrm{~d}, J=9.1 \mathrm{~Hz}) ;$ $128.9(\mathrm{~d}, J=11.0 \mathrm{~Hz}) ; 41.7(\mathrm{~d}, J=8.1 \mathrm{~Hz}) ; 41.1(\mathrm{~d}, J=68.9 \mathrm{~Hz}) ; 29.9(\mathrm{~d}, J=65.4 \mathrm{~Hz}) ; 28.8(\mathrm{~d}, J=3.0 \mathrm{~Hz})$; $27.6(\mathrm{~d}, J=13.6 \mathrm{~Hz}) ; 27.3(\mathrm{~s}) ; 26.5(\mathrm{~d}, J=11.5 \mathrm{~Hz}) ; 25.1(\mathrm{~d}, J=3.3 \mathrm{~Hz}) ; 22.7(\mathrm{~d}, J=1.7 \mathrm{~Hz}) ; 20.9 .{ }^{31} \mathrm{P}$ NMR $\left(\mathrm{CDCl}_{3}, 121.5 \mathrm{MHz}\right): \delta 61.86$ (s). Elemental Anal. For $\mathrm{C}_{16} \mathrm{H}_{21} \mathrm{OP}$ : calcd. C, 73.82; $\mathrm{H}, 8.13$; found C, $73.72 ; \mathrm{H}, 8.10$.

3.2.29. Synthesis of $\left(R_{\mathrm{P}}\right)$-3-Phenyl-3-phosphatricyclo[5.2.2.0 2,6] undecane (30)

$\left(R_{\mathrm{P}}\right)$-30 was obtained in 93\% yield according to typical procedure described in Section 3.2.4. $\left(R_{\mathrm{P}}\right)$-30: a colorless oil, bp $=180{ }^{\circ} \mathrm{C} / 0.1 \mathrm{mmHg},[\alpha]_{\mathrm{D}}=-8.79\left(c 1.8, \mathrm{CHCl}_{3}\right) .{ }^{1} \mathrm{H} \mathrm{NMR}\left(\mathrm{CDCl}_{3}, 300 \mathrm{MHz}\right)$ : $\delta$ 7.66-7.30 (m, 2H); 7.26-7.13 (m, 3H); 2.42-2.31 (m, 2H); 2.04-1.81 (m, 6H); 1.61-1.28 (m, 8H). ${ }^{13} \mathrm{C} \mathrm{NMR}$ $\left(\mathrm{CDCl}_{3}, 75.5 \mathrm{MHz}\right): \delta 142.6(\mathrm{~d}, J=20.7 \mathrm{~Hz}) ; 131.2(\mathrm{~d}, J=15.4 \mathrm{~Hz}) ; 128.6(\mathrm{~d}, J=5.4 \mathrm{~Hz}) ; 127.8 ; 46.8(\mathrm{~d}$, $J=9.9 \mathrm{~Hz}) ; 43.8(\mathrm{~d}, J=2 \mathrm{~Hz}) ; 33.0(\mathrm{~d}, J=2.3 \mathrm{~Hz}) ; 30.12 ; 29.5(\mathrm{~d}, J=23.2 \mathrm{~Hz}) ; 28.0(\mathrm{~d}, J=10.8 \mathrm{~Hz}) ; 27.7$; $27.6(\mathrm{~d}, J=9 \mathrm{~Hz}) ; 22.8(\mathrm{~d}, J=10.8 \mathrm{~Hz}) ; 21.3 .{ }^{31} \mathrm{P} \mathrm{NMR}\left(\mathrm{CDCl}_{3}, 121.5 \mathrm{MHz}\right): \delta 2.85$. The configuration and high enantiomeric purity of $\left(R_{\mathrm{P}}\right)-30$ was confirmed by its oxidation by $\mathrm{H}_{2} \mathrm{O}_{2}$ which afforded back $\left(S_{\mathrm{P}}\right)-29$ of $[\alpha]_{\mathrm{D}}=-5.38\left(c 1.24, \mathrm{CHCl}_{3}\right)$.

3.2.30. Synthesis of $\left(R_{\mathrm{P}}\right)$-3-Phenyl-3-phosphatricyclo[5.2.2.02,6] ${ }^{2}$ undecane-borane (31)

$\left(R_{\mathrm{P}}\right)$-31 was obtained in $96 \%$ yield according to typical procedure described in Section 3.2.9. with using $1 \mathrm{M} \mathrm{BH}_{3}$-THF instead of $\mathrm{BH}_{3}-\mathrm{SMe}_{2}$. $\left(\boldsymbol{R}_{\mathrm{P}}\right)-31$ : a white solid, $\mathrm{mp}=60-62{ }^{\circ} \mathrm{C},[\alpha]_{\mathrm{D}}=-9.3(\mathrm{c} 1.2$, $\left.\mathrm{CHCl}_{3}\right) .{ }^{1} \mathrm{H}$ NMR $\left(\mathrm{CDCl}_{3}, 300 \mathrm{MHz}\right): \delta 7.73-7.63(\mathrm{~m}, 2 \mathrm{H}) ; 7.48-7.39(\mathrm{~m}, 3 \mathrm{H}) ; 2.73-2.37(\mathrm{~m}, 2 \mathrm{H}) ; 2.20-2.01$ $(\mathrm{m}, 6 \mathrm{H}) ; 1.76-1.68(\mathrm{~m}, 4 \mathrm{H}) ; 1.64-1.51(\mathrm{~m}, 3 \mathrm{H}) ; 1.47-1.29(\mathrm{~m}, 1 \mathrm{H}) ; 1.29-0.30\left(\mathrm{~m}, 3 \mathrm{H}, \mathrm{BH}_{3}\right) .{ }^{13} \mathrm{C} \mathrm{NMR}$ $\left(\mathrm{CDCl}_{3}, 75.5 \mathrm{MHz}\right): \delta 135.4(\mathrm{~d}, J=1.49 \mathrm{~Hz}) ; 132.8(\mathrm{~s}) ; 132.3(\mathrm{~d}, J=46.5 \mathrm{~Hz}) ; 131.7(\mathrm{~d}, J=8.0 \mathrm{~Hz}) ; 131.1$ $(\mathrm{d}, J=2.4 \mathrm{~Hz}) ; 129.1(\mathrm{~d}, J=9.1 \mathrm{~Hz}) ; 47.0(\mathrm{~s}) ; 44.5(\mathrm{~d}, J=35.9 \mathrm{~Hz}) ; 36.3(\mathrm{~s}) ; 32.2(\mathrm{~d}, J=3.0 \mathrm{~Hz}) ; 32.0(\mathrm{~d}$, $J=4.7 \mathrm{~Hz}) ; 26.8(\mathrm{~d}, J=12.4 \mathrm{~Hz}) ; 26.4(\mathrm{~d}, J=35.1 \mathrm{~Hz}) ; 25.1(\mathrm{~s}) .{ }^{31} \mathrm{P} \mathrm{NMR}\left(\mathrm{CDCl}_{3}, 121.5 \mathrm{MHz}\right): \delta 39.35$. Elemental Anal. For $\mathrm{C}_{16} \mathrm{H}_{24} \mathrm{BP}$ : calcd. C, 74.44; H, 9.37; found C, 74.22; H, 9.34 .

3.2.31. Synthesis of $\left(S_{\mathrm{P}}\right)$-3-Phenyl-3-phosphatricyclo[5.2.2.02,6]undecane 3-sulfide (32)

$\left(S_{\mathrm{P}}\right)$-32 was obtained in $95 \%$ yield according to typical procedure described in Section 3.2.6. $\left(R_{\mathrm{P}}\right)-32$ : white crystals, $\mathrm{mp}=124-125^{\circ} \mathrm{C},[\alpha]_{\mathrm{D}}=+2.8\left(c 1.03, \mathrm{CHCl}_{3}\right) .{ }^{1} \mathrm{H} \mathrm{NMR}\left(\mathrm{CDCl}_{3}, 300 \mathrm{MHz}\right)$ :

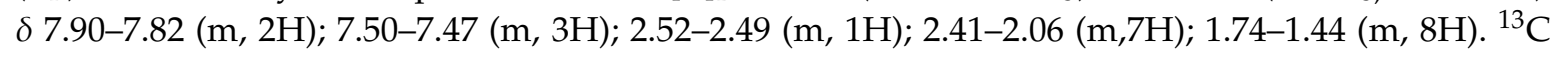
NMR (CDCl $3,75.5 \mathrm{MHz}): \delta 135.2(\mathrm{~d}, J=70.0 \mathrm{~Hz}) ; 131.5(\mathrm{~d}, J=2.9 \mathrm{~Hz}) ; 130.6(\mathrm{~d}, J=9.7 \mathrm{~Hz}) ; 129.0(\mathrm{~d}$, 
$J=11.3 \mathrm{~Hz}) ; 43.1(\mathrm{~d}, J=24.7 \mathrm{~Hz}) ; 42.6(\mathrm{~d}, J=20.2 \mathrm{~Hz}) ; 35.6(\mathrm{~d}, J=52.0 \mathrm{~Hz}) ; 30.0(\mathrm{~d}, J=2.73 \mathrm{~Hz}) ; 28.1(\mathrm{~d}$, $J=10.6 \mathrm{~Hz}) ; 27.5(\mathrm{~d}, J=14.6 \mathrm{~Hz}) ; 26.4(\mathrm{~d}, J=70.8 \mathrm{~Hz}) ; 22.1(\mathrm{~d}, J=2.1 \mathrm{~Hz}) ; 20.6 .{ }^{31} \mathrm{P} \mathrm{NMR}\left(\mathrm{CDCl}_{3}\right.$, 121,5 MHz): $\delta$ 65.93. Elemental Anal. For $\mathrm{C}_{16} \mathrm{H}_{21}$ SP: calcd. C, 69.53; $\mathrm{H}, 7.65$; found C, 69.43; H, 7.63.

3.2.32. Synthesis of $\left(S_{P}\right)$-3-Phenyl-3-phosphatricyclo[5.2.2.02,6] undecane 3-selenide (33)

$\left(S_{\mathrm{P}}\right)$-33 was obtained in 95\% yield according to typical procedure described in Section 3.2.7. $\left(S_{\mathrm{P}}\right)$-33: white crystals, $\mathrm{mp}=146-147^{\circ} \mathrm{C},[\alpha]_{\mathrm{D}}=-0.95\left(c 0.97, \mathrm{CHCl}_{3}\right) .{ }^{1} \mathrm{H} \mathrm{NMR}\left(\mathrm{CDCl}_{3}, 300 \mathrm{MHz}\right)$ : $\delta$ 7.87-7.84 (m, 2H); 7.52-7.46 (m, 3H); 2.53-2.34 (m, 5H); 2.22-2.05 (m, 3H); $1.74-1.42(\mathrm{~m}, 8 \mathrm{H}) .{ }^{13} \mathrm{C}$ NMR (CDCl, $75.5 \mathrm{MHz}): \delta 134.0(\mathrm{~d}, J=62.2 \mathrm{~Hz}) ; 131.6(\mathrm{~d}, J=2.9 \mathrm{~Hz}) ; 131.0(\mathrm{~d}, J=9.7 \mathrm{~Hz}) ; 129.0(\mathrm{~d}$, $J=11.2 \mathrm{~Hz}) ; 43.1(\mathrm{~d}, J=6.0 \mathrm{~Hz}) ; 42.6(\mathrm{~d}, J=44.6 \mathrm{~Hz}) ; 36.0(\mathrm{~d}, J=45.7 \mathrm{~Hz}) ; 30.2(\mathrm{~d}, J=2.5 \mathrm{~Hz}) ; 29.0(\mathrm{~d}$, $J=9.3 \mathrm{~Hz}) ; 27.5(\mathrm{~d}, J=14.9 \mathrm{~Hz}) ; 26.9 ; 26.8(\mathrm{~d}, J=1.2 \mathrm{~Hz}) ; 21.8(\mathrm{~d}, J=2.3 \mathrm{~Hz}) ; 20.5(\mathrm{~s}) .{ }^{31} \mathrm{P} \mathrm{NMR}\left(\mathrm{CDCl}_{3}\right.$, 121.5 MHz): $\delta$ 52.94. Elemental Anal. For $\mathrm{C}_{16} \mathrm{H}_{21} \mathrm{SeP}$ : calcd. C, 59.44; $\mathrm{H}, 6.54$; found $\mathrm{C}, 59.22 ; \mathrm{H}, 6.50$.

3.2.33. Synthesis of $\left(S_{\mathrm{P}}\right)$-Dibenzo[a,d]-3-Phenyl-3-phosphatricyclo[5.2.2.02.6]undeca-8,10-diene 3-oxide (34)

In a tightly closed glass ampoule was placed $2 \mathrm{~g}(0.011 \mathrm{~mol})$ of $\left(S_{\mathrm{P}}\right)-4,3.9 \mathrm{~g}(0.022 \mathrm{~mol})$ of anthracene, and $0.019 \mathrm{~g}(0.089 \mathrm{mmol})$ of 2.6-di-tert-butyl-4-methylphenol in $7 \mathrm{~mL}$ of toluene. The reaction mixture was then heated at $200{ }^{\circ} \mathrm{C}$ for $48 \mathrm{~h}$. After that time, the reaction mixture was evaporated under reduced pressure and the residue was passed through a silica gel column using $\mathrm{AcOEt} / \mathrm{CH}_{3} \mathrm{OH}(30: 1)$ as eluent to give a white solid which was recrystallized from toluene/hexane to yield $3.4 \mathrm{~g}(86 \%)$ of $\left(S_{\mathrm{P}}\right)-34$ : white crystals, $\mathrm{mp}=251-252{ }^{\circ} \mathrm{C},[\alpha]_{\mathrm{D}}=-12.3\left(c 1.1, \mathrm{CHCl}_{3}\right) .{ }^{1} \mathrm{H} \mathrm{NMR}\left(\mathrm{CDCl}_{3}, 300 \mathrm{MHz}\right): \delta 7.63-7.56$ $(\mathrm{m}, 3 \mathrm{H}) ; 7.5-7.37(\mathrm{~m}, 3 \mathrm{H}) ; 7.32-7.08(\mathrm{~m}, 7 \mathrm{H}) ; 4.87(\mathrm{t}, 1 \mathrm{H}, J=2.9 \mathrm{~Hz}) ; 4.29(\mathrm{bs}, 1 \mathrm{H}) ; 2.93-2.81(\mathrm{~m}, 1 \mathrm{H})$; 2.61-2.55 (m, 1H); 1.87-1.70 (m, 2H); 1.52-1.23 (m, 1H); 0.28-0.13 (m, 1H). ${ }^{13} \mathrm{C} \mathrm{NMR}\left(\mathrm{CDCl}_{3}, 75.5 \mathrm{MHz}\right)$ : $\delta 143.6(\mathrm{~d}, J=1.6 \mathrm{~Hz}) ; 143.4 ; 141.0 ; 140.6(\mathrm{~d}, J=2.6 \mathrm{~Hz}) ; 134.3(\mathrm{~d}, J=88.3 \mathrm{H}) ; 131.7(\mathrm{~d}, J=2.7 \mathrm{~Hz}) ; 129.8$ $(\mathrm{d}, J=9 \mathrm{~Hz}) ; 128.8(\mathrm{~d}, J=11 \mathrm{~Hz}) ; 126.9 ; 126.6 ; 126.4 ; 126.2 ; 126.0 ; 124.6 ; 123.8 ; 123.0 ; 51.1(\mathrm{~d}, J=1.5 \mathrm{~Hz}) ;$ $44.1(\mathrm{~d}, J=1.6 \mathrm{~Hz}) ; 42.4(\mathrm{~d}, J=13.8 \mathrm{~Hz}) ; 41.9(\mathrm{~d}, J=70 \mathrm{~Hz}) ; 26.4(\mathrm{~d}, J=66 \mathrm{~Hz}) ; 24.5(\mathrm{~d}, J=11.6 \mathrm{~Hz}) .{ }^{31} \mathrm{P}$ NMR ( $\left.\mathrm{CDCl}_{3}, 121.5 \mathrm{MHz}\right): \delta 58.65$ (s). Elemental Anal. For $\mathrm{C}_{24} \mathrm{H}_{21} \mathrm{OP}$ : calcd. C, 80.88; $\mathrm{H}, 5.94$; found C, 80.70; H, 5.90 .

3.2.34. Synthesis of $\left(R_{\mathrm{P}}\right)$-Dibenzo[a,d]-3-Phenyl-3-phosphatricyclo[5.2.2.02.6] undeca-8,10-diene (35)

A three-neck flask equipped with a reflux condenser and a septum was charged with $2.7 \mathrm{~g}(0.034$ mol) of pyridine in $68 \mathrm{~mL}$ of benzene. Then, $1.54 \mathrm{~g}\left(0.011\right.$ mole) of $\mathrm{Cl}_{3} \mathrm{SiH}$ was added followed by $0.81 \mathrm{~g}$ $(0.0022 \mathrm{~mol})$ of oxide $\left(S_{\mathrm{P}}\right)-34$ dissolved in benzene, and the reaction mixture was heated at $80^{\circ} \mathrm{C}$ for $8 \mathrm{~h}$. After the reaction mixture was cooled to room temperature, $20 \mathrm{~mL}$ of $30 \% \mathrm{NaOH}$ was added slowly over a period of $1 \mathrm{~h}$. The organic layer was separated, dried over anhydrous $\mathrm{MgSO}_{4}$, and concentrated under reduced pressure. The crude product was crystallized from methanol and yielded $0.76 \mathrm{~g}(98 \%)$ of phosphine $\left(R_{\mathrm{P}}\right)-35$ : white crystals, $\mathrm{mp}=189-190^{\circ} \mathrm{C},[\alpha]_{\mathrm{D}}=-6.38\left(c 1.5, \mathrm{CHCl}_{3}\right) .{ }^{1} \mathrm{H} \mathrm{NMR}\left(\mathrm{CDCl}_{3}\right.$, $300 \mathrm{MHz}): \delta 7.42-6.96(\mathrm{~m}, 13 \mathrm{H}) ; 4.51(\mathrm{dd}, 1 \mathrm{H}, J=2.4 \mathrm{~Hz}, 4.3 \mathrm{~Hz}) ; 4.12(\mathrm{~d}, 1 \mathrm{H}, J=2.5 \mathrm{~Hz}) ; 2.88-2.76$ $(\mathrm{m}, 2 \mathrm{H}) ; 1.9-1.7(\mathrm{~m}, 2 \mathrm{H}) ; 1.31(\mathrm{ddd}, 1 \mathrm{H}, J=2 \mathrm{~Hz}, 6.5 \mathrm{~Hz}, 14 \mathrm{~Hz}) ; 0.07-0.12(\mathrm{~m}, 1 \mathrm{H}) .{ }^{13} \mathrm{C} \mathrm{NMR}\left(\mathrm{CDCl}_{3}\right.$, $75.5 \mathrm{MHz}): \delta 144.5(\mathrm{~d}, J=12.9 \mathrm{~Hz}) ; 144.0 ; 141.7 ; 141.4(\mathrm{~d}, J=3.1 \mathrm{~Hz}) ; 140.2(\mathrm{~d}, J=23 \mathrm{~Hz}) ; 129.0(\mathrm{~d}$, $J=15.4 \mathrm{~Hz}$ ); $128.3 ; 128.2 ; 126.4 ; 125.9(\mathrm{~d}, J=12.7 \mathrm{~Hz}) ; 125.8 ; 125.3(\mathrm{~d}, J=2 \mathrm{~Hz}) ; 124.9 ; 123.5 ; 123.2 ; 51.1$; $49.0(\mathrm{~d}, J=27 \mathrm{~Hz}) ; 48.5$ (d, $J=14.3 \mathrm{~Hz}) ; 47.4(\mathrm{~d}, J=4.4 \mathrm{~Hz}) ; 32.9$ (d, $J=4.4 \mathrm{~Hz}) ; 26.4(\mathrm{~d}, J=12.5 \mathrm{~Hz})$. ${ }^{31} \mathrm{P} \mathrm{NMR}\left(\mathrm{CDCl}_{3}, 121.5 \mathrm{MHz}\right): \delta 4.12$. The configuration and high enantiomeric purity of $\left(R_{\mathrm{P}}\right)-30$ was confirmed by its oxidation by $\mathrm{H}_{2} \mathrm{O}_{2}$ which afforded back $\left(S_{\mathrm{P}}\right)-29$ of $[\alpha]_{\mathrm{D}}=-11.95\left(c 0.88, \mathrm{CHCl}_{3}\right)$.

3.2.35. Synthesis of $\left(R_{\mathrm{P}}\right)$-Dibenzo[a,d]-3-Phenyl-3-phosphatricyclo[5.2.2.02.6]undeca-8,10-diene -borane (36)

$\left(R_{\mathrm{P}}\right)$-36 was obtained in $96 \%$ yield according to typical procedure described in Section 3.2.9. $\left(\boldsymbol{R}_{\mathbf{P}}\right)-36$ : a crystalline solid, $\mathrm{mp}=243-244^{\circ} \mathrm{C},[\alpha]_{\mathrm{D}}=-25.95\left(c 1.3, \mathrm{CHCl}_{3}\right) .{ }^{1} \mathrm{H} \mathrm{NMR}\left(\mathrm{CDCl}_{3}, 300 \mathrm{MHz}\right)$ : $\delta 7.63(\mathrm{~m}, 1 \mathrm{H}) ; 7.57-7.5(\mathrm{~m}, 1 \mathrm{H}) ; 7.42-7.13(\mathrm{~m}, \mathrm{H}) ; 4.83(\mathrm{dd}, 1 \mathrm{H}, J=2.2 \mathrm{~Hz}, 3.9 \mathrm{~Hz}) ; 4.29(\mathrm{~d}, 1 \mathrm{H}, J=3.3 \mathrm{~Hz})$; 
3.07-3.00 (m, 1H); 2.86-2.81 (m, 1H); 2.01-1.84 (m, 2H); $1.65(\mathrm{~m}, 1 \mathrm{H}) ; 0.39-0.26(\mathrm{~m}, 1 \mathrm{H}) ; 1.50-0.6(\mathrm{~m}, 3 \mathrm{H}$, $\left.\mathrm{BH}_{3}\right) .{ }^{13} \mathrm{C}$ NMR $\left(\mathrm{CDCl}_{3}, 75.5 \mathrm{MHz}\right): \delta 144.7(\mathrm{~d}, J=12.4 \mathrm{~Hz}) ; 143.7 ; 141.6 ; 140.2(\mathrm{~d}, J=1.5 \mathrm{~Hz}) ; 131.4(\mathrm{~d}$, $J=44.6 \mathrm{~Hz}) ; 131.3(\mathrm{~d}, J=8 \mathrm{~Hz}) ; 131.1(\mathrm{~d}, J=2.4 \mathrm{~Hz}) ; 129.2(\mathrm{~d}, J=9.2 \mathrm{~Hz}) ; 126.8 ; 126.6 ; 126.5 ; 125.1$; 124.4; 123.4; 50.9; $45.8(\mathrm{~d}, J=1.5 \mathrm{~Hz}) ; 45.3(\mathrm{~d}, J=3.1 \mathrm{~Hz}) ; 44.1(\mathrm{~d}, J=31.6 \mathrm{~Hz}) ; 30.0 ; 25.5(\mathrm{~d}, J=32 \mathrm{~Hz})$. ${ }^{31} \mathrm{P}$ NMR $\left(\mathrm{CDCl}_{3}, 121.5 \mathrm{MHz}\right): \delta 42.56$.

3.2.36. Synthesis of $\left(S_{\mathrm{P}}\right)$-Dibenzo[a,d]-3-Phenyl-3-phosphatricyclo[5.2.2.02.6]undeca-8,10-diene 3-sulfide (37)

$\left(S_{\mathrm{P}}\right)$-37 was obtained in $92 \%$ yield according to typical procedure described in Section 3.2.6. $\left(R_{\mathrm{P}}\right)$-37: white crystals, $\mathrm{mp}=259-260^{\circ} \mathrm{C},[\alpha]_{\mathrm{D}}=+14.02\left(c 1.32, \mathrm{CHCl}_{3}\right) .{ }^{1} \mathrm{H} \mathrm{NMR}\left(\mathrm{CDCl}_{3}, 300 \mathrm{MHz}\right)$ : $\delta$ 7.75-7.65 (m, 3H); 7.43-7.05 (m, 11H); $5.04(\mathrm{dd}, 1 \mathrm{H}, J=1.7 \mathrm{~Hz}, 4.5 \mathrm{~Hz}) ; 4.30(\mathrm{~s}, 1 \mathrm{H}) ; 3.10-2.95(\mathrm{~m}$, $1 \mathrm{H}) ; 2.85-2.75(\mathrm{~m}, 1 \mathrm{H}) ; 1.97-1.70(\mathrm{~m}, 3 \mathrm{H}) ; 0.36-0.25(\mathrm{~m}, 1 \mathrm{H}) .{ }^{13} \mathrm{C} \mathrm{NMR}\left(\mathrm{CDCl}_{3}, 75.5 \mathrm{MHz}\right): \delta 143.8$ $(\mathrm{d}, J=13 \mathrm{~Hz}) ; 143.5 ; 141.3 ; 139.8(\mathrm{~d}, J=2.3 \mathrm{~Hz}) ; 134.5(\mathrm{~d}, J=71.8 \mathrm{~Hz}) ; 131.3(\mathrm{~d}, J=2.8 \mathrm{~Hz}) ; 130.1(\mathrm{~d}$, $J=9.6 \mathrm{~Hz}) ; 128.7(\mathrm{~d}, J=11.3 \mathrm{~Hz}) ; 128.6 ; 126.4 ; 126.4 ; 126.1 ; 124.6 ; 123.9 ; 123.2 ; 51.2(\mathrm{~d}, J=1.5 \mathrm{~Hz}) ; 45.0$ $(\mathrm{d}, J=21.5 \mathrm{~Hz}) ; 44.7(\mathrm{~d}, J=31.2 \mathrm{~Hz}) ; 44.3(\mathrm{~d}, J=10.7 \mathrm{~Hz}) ; 32.2(\mathrm{~d}, J=50.6 \mathrm{~Hz}) ; 27.2(\mathrm{~d}, J=7.6 \mathrm{~Hz}) .{ }^{31} \mathrm{P}$ NMR ( $\left.\mathrm{CDCl}_{3}, 121.5 \mathrm{MHz}\right): \delta$ 63.30. Elemental Anal. for $\mathrm{C}_{24} \mathrm{H}_{21} \mathrm{SP}$ : calcd. C, 77.39; $\mathrm{H}, 5.68$; found $\mathrm{C}$, 77.29; H, 5.64 .

3.2.37. Synthesis of $\left(S_{\mathrm{P}}\right)$-Dibenzo[a,d]-3-Phenyl-3-phosphatricyclo[5.2.2.02.6]undeca-8,10-diene 3-selenide (38)

$\left(S_{\mathrm{P}}\right)-\mathbf{3 8}$ was obtained in $95 \%$ yield according to typical procedure described in Section 3.2.7. To the solution of $2 \mathrm{~g}(0.0058 \mathrm{~mol})$ of $\left(R_{\mathrm{P}}\right)-35 \mathrm{in} 10 \mathrm{~mL}$ of benzene was added $0.46 \mathrm{~g}(0.0058 \mathrm{~mol})$ of selenium under argon and the reaction mixture was stirred at room temperature for $24 \mathrm{~h}$. After this time, the reaction mixture was concentrated and the crude product was purified by column chromatography using $\mathrm{CH}_{2} \mathrm{Cl}_{2}$ /hexane (1:1) as eluent followed by crystallization from methanol to yield $2.21 \mathrm{~g}(90 \%)$ of selenide $\left(S_{\mathrm{P}}\right)-38$ : white crystals, $\left.\mathrm{mp}=248-249^{\circ} \mathrm{C},[\alpha]_{\mathrm{D}}=+15.07\left(c 1.04, \mathrm{CHCl}_{3}\right)\right) .{ }^{1} \mathrm{H} \mathrm{NMR}\left(\mathrm{CDCl}_{3}\right.$, $300 \mathrm{MHz}): \delta 7.74-7.66(\mathrm{~m}, 3 \mathrm{H}) ; 7.41-7.15(\mathrm{~m}, 10 \mathrm{H}) ; 5.10(\mathrm{dd}, 1 \mathrm{H}, J=2.4 \mathrm{~Hz}, 5.4 \mathrm{~Hz}) ; 4.3(\mathrm{dd}, 1 \mathrm{H}$, $J=2.4 \mathrm{~Hz}, 2.7 \mathrm{~Hz}) ; 3.05-2.98(\mathrm{~m}, 1 \mathrm{H}) ; 2.90-2.85(\mathrm{~m}, 1 \mathrm{H}) ; 1.92-1.80(\mathrm{~m}, 3 \mathrm{H}) ; 0.42-0.34(\mathrm{~m}, 1 \mathrm{H}) .{ }^{13} \mathrm{C}$ NMR $\left(\mathrm{CDCl}_{3}, 75.5 \mathrm{MHz}\right): \delta 144.2(\mathrm{~d}, J=13.4 \mathrm{~Hz}) ; 143.9 ; 141.7 ; 139.8(\mathrm{~d}, J=2.2 \mathrm{~Hz}) ; 133.9(\mathrm{~d}, J=63.7 \mathrm{~Hz}) ; 131.6$ $(\mathrm{d}, J=3 \mathrm{~Hz}) ; 130.7(\mathrm{~d}, J=9.5 \mathrm{~Hz}) ; 129.5 ; 129.1(\mathrm{~d}, J=11.3 \mathrm{~Hz}) ; 128.8(\mathrm{~d}, J=3 \mathrm{~Hz}) ; 126.8(\mathrm{~d}, J=3 \mathrm{~Hz})$; 126.8; 126.7; 126.4; 124.9; 124.3; 123.6; $51.4(\mathrm{~d}, J=1.3 \mathrm{~Hz}) ; 46.0(\mathrm{~d}, J=1.4 \mathrm{~Hz}) ; 45.3(\mathrm{~d}, J=1.2 \mathrm{~Hz}) ; 44.8(\mathrm{~d}$, $J=37 \mathrm{~Hz}) ; 33.0(\mathrm{~d}, J=44 \mathrm{~Hz}) ; 28.8(\mathrm{~d}, J=5.5 \mathrm{~Hz}) .{ }^{31} \mathrm{P} \mathrm{NMR}\left(\mathrm{CDCl}_{3}, 121.5 \mathrm{MHz}\right): \delta 49.52(\mathrm{~s})$. Elemental Anal. For $\mathrm{C}_{24} \mathrm{H}_{21} \mathrm{SeP}$ : calcd. C, 77.39; $\mathrm{H}, 5.68$; found C, 77.29; $\mathrm{H}, 5.64$.

3.2.38. Synthesis of $\left(S_{\mathrm{P}}\right)$-1-Phenyl-2,3,3a,4,9,9a-hexahydrophosphacyclopenta[b]naphthalen-9-ol 1-oxide (39)

In a Schlenk flask under argon atmosphere was placed $0.8 \mathrm{~g}(0.0067 \mathrm{~mol})$ of benzocyclobutenol dissolved in $120 \mathrm{~mL}$ of THF, and all of it was cooled down to $-78^{\circ} \mathrm{C}$ with stirring. After $1 \mathrm{~h}, 5 \mathrm{~mL}$ of $1.6 \mathrm{M} \mathrm{n}$-BuLi (1.1 equiv.) was added dropwise and the resulting mixture was stirred at $-78^{\circ} \mathrm{C}$ for $0.5 \mathrm{~h}$. Then, $1 \mathrm{~g}(0.0056 \mathrm{~mol})$ of $\left(S_{\mathrm{P}}\right)-4 \mathrm{in}$ THF was added dropwise and the reaction mixture was stirred at $-78^{\circ} \mathrm{C}$ for $2 \mathrm{~h}$, and then at $0{ }^{\circ} \mathrm{C}$ for $1 \mathrm{~h}$. Next, the volatiles were removed from the reaction mixture and the residue was dissolved in $\mathrm{CH}_{2} \mathrm{Cl}_{2}(120 \mathrm{~mL})$ and washed with saturated aq. $\mathrm{NH}_{4} \mathrm{Cl}(50 \mathrm{~mL})$ and $\mathrm{H}_{2} \mathrm{O}$ $(2 \times 35 \mathrm{~mL})$. The separated organic layer was dried over anhydrous $\mathrm{MgSO}_{4}$, filtered and evaporated under reduced pressure. The residue was purified by column chromatography using $\mathrm{CHCl}_{3} /$ acetone (35:1) as eluent to yield $1.5 \mathrm{~g}(90 \%)$ of oxide $\left(S_{\mathrm{P}}\right)-39$ : a white crystalline solid. $\mathrm{mp}=145-147{ }^{\circ} \mathrm{C}$, $[\alpha]_{\mathrm{D}}=-46.95\left(c 1.22, \mathrm{CHCl}_{3}\right) .{ }^{1} \mathrm{H}$ NMR $\left(\mathrm{CDCl}_{3}, 300 \mathrm{MHz}\right): \delta$ 7.8-7.72 (m, 2H); 7.55-7.51 (m, 3H); $7.31-7.2(\mathrm{~m}, 4 \mathrm{H}) ; 5.22(\mathrm{dd}, 1 \mathrm{H}, J=4 \mathrm{~Hz} ; 8.8 \mathrm{~Hz}) ; 4.97(\mathrm{~d}, 1 \mathrm{H}, J=7.9 \mathrm{~Hz}) ; 3.14(\mathrm{dd}, 1 \mathrm{H}, J=8 \mathrm{~Hz} ; 14.5 \mathrm{~Hz})$; $3.0(\mathrm{ddd}, 1 \mathrm{H}, J=1.3 \mathrm{~Hz}, 6.8 \mathrm{~Hz}, 15.7 \mathrm{~Hz}) ; 2.66-2.63(\mathrm{~m}, 1 \mathrm{H}) ; 2.55-2.33(\mathrm{~m}, 2 \mathrm{H}) ; 2.2-2.1(\mathrm{~m}, 2 \mathrm{H}) ; 1.98-1.86$ (m, 1H). ${ }^{13} \mathrm{C} \mathrm{NMR}\left(\mathrm{CDCl}_{3}, 75.5 \mathrm{MHz}\right): \delta 139.5(\mathrm{~d}, J=8.2 \mathrm{~Hz}) ; 137.7 ; 132.8(\mathrm{~d}, J=90 \mathrm{~Hz}) ; 132.6(\mathrm{~d}$, $J=2.8 \mathrm{~Hz}) ; 130.6(\mathrm{~d}, J=9.9 \mathrm{~Hz}) ; 129.4(\mathrm{~d}, J=11.4 \mathrm{~Hz}) ; 128.5 ; 128.4 ; 126.9 ; 126.8 ; 70.6(\mathrm{~d}, J=5.5 \mathrm{~Hz}) ; 43.7$ 
$(\mathrm{d}, J=67 \mathrm{~Hz}) ; 38.0(\mathrm{~d}, J=10.4 \mathrm{~Hz}) ; 34.3(\mathrm{~d}, J=4.4 \mathrm{~Hz}) ; 32.2(\mathrm{~d}, J=8.7 \mathrm{~Hz}) ; 30.0(\mathrm{~d}, J=65.3 \mathrm{~Hz}) .{ }^{31} \mathrm{P}$ NMR ( $\left.\mathrm{CDCl}_{3}, 121.5 \mathrm{MHz}\right): \delta 65.17$ (s). Elemental Anal. For $\mathrm{C}_{18} \mathrm{H}_{19} \mathrm{O}_{2} \mathrm{P}$ : calcd. C, 72.47; $\mathrm{H}, 6.42$; found C, $72.37 ; \mathrm{H}, 6.40$.

3.2.39. Synthesis of $\left(R_{\mathrm{P}}\right)-1-P h e n y l-2,3,3 \mathrm{a}, 4,9,9 \mathrm{a}-\mathrm{h}$ exahydrophosphacyclopenta[b]naphthalen-9-ol (40)

$\left(R_{\mathrm{P}}\right)-\mathbf{4 0}$ was obtained in $97 \%$ yield according to procedure described in Section 3.2.32. $\left(R_{\mathrm{P}}\right)-\mathbf{4 0}$ : a thick oil, $[\alpha]_{\mathrm{D}}=-10.8\left(c 1.5, \mathrm{CHCl}_{3}\right) .{ }^{1} \mathrm{H}$ NMR $\left(\mathrm{CDCl}_{3}, 300 \mathrm{MHz}\right): \delta 7.8-7.72(\mathrm{~m}, 2 \mathrm{H}) ; 7.55-7.51(\mathrm{~m}$, $3 \mathrm{H}) ; 7.31-7.2(\mathrm{~m}, 4 \mathrm{H}) ; 5.22(\mathrm{dd}, 1 \mathrm{H}, J=4 \mathrm{~Hz} ; 8.8 \mathrm{~Hz}) ; 4.97(\mathrm{~d}, 1 \mathrm{H}, J=7.9 \mathrm{~Hz}) ; 3.14(\mathrm{dd}, 1 \mathrm{H}, J=8 \mathrm{~Hz}$; $14.5 \mathrm{~Hz}) ; 3.0(\mathrm{ddd}, 1 \mathrm{H}, J=1.3 \mathrm{~Hz}, 6.8 \mathrm{~Hz}, 15.7 \mathrm{~Hz}) ; 2.66-2.63(\mathrm{~m}, 1 \mathrm{H}) ; 2.55-2.33(\mathrm{~m}, 2 \mathrm{H}) ; 2.2-2.1(\mathrm{~m}, 2 \mathrm{H})$; 1.98-1.86 (m, 1H). ${ }^{13} \mathrm{C}$ NMR $\left(\mathrm{CDCl}_{3}, 75.5 \mathrm{MHz}\right): \delta 139.5(\mathrm{~d}, J=8.2 \mathrm{~Hz}) ; 137.7 ; 132.8(\mathrm{~d}, J=90 \mathrm{~Hz}) ; 132.6$ $(\mathrm{d}, J=2.8 \mathrm{~Hz}) ; 130.6(\mathrm{~d}, J=9.9 \mathrm{~Hz}) ; 129.4(\mathrm{~d}, J=11.4 \mathrm{~Hz}) ; 128.5 ; 128.4 ; 126.9 ; 126.8 ; 70.6(\mathrm{~d}, J=5.5 \mathrm{~Hz}) ;$ $43.7(\mathrm{~d}, J=67 \mathrm{~Hz}) ; 38.0(\mathrm{~d}, J=10.4 \mathrm{~Hz}) ; 34.3(\mathrm{~d}, J=4.4 \mathrm{~Hz}) ; 32.2(\mathrm{~d}, J=8.7 \mathrm{~Hz}) ; 30.0(\mathrm{~d}, J=65.3 \mathrm{~Hz}) .{ }^{31} \mathrm{P}$ $\mathrm{NMR}\left(\mathrm{CDCl}_{3}, 121.5 \mathrm{MHz}\right): \delta-8.82$. The configuration and high enantiomeric purity of $\left(R_{\mathrm{P}}\right)-\mathbf{4 0}$ was confirmed by its oxidation by $\mathrm{H}_{2} \mathrm{O}_{2}$ which afforded back $\left(S_{\mathrm{P}}\right)-39$ of $[\alpha]_{\mathrm{D}}=-46.6\left(c 1.05, \mathrm{CHCl}_{3}\right)$.

It is important to note in this place that a primarily attempted reduction of $\left(S_{\mathrm{P}}\right)-39$ by $\mathrm{PhSiH}_{3}$ under our standard conditions (toluene, $80^{\circ} \mathrm{C}, 24 \mathrm{~h}$ ) led to the formation of two P-epimeric phosphine products as revealed by ${ }^{31} \mathrm{P}$ NMR spectrum of the crude post-reduction mixture showing two signals at -8.35 and $-3.67 \mathrm{ppm}(7: 3)$ indicating that a partial inversion at $\mathrm{P}$ in $\left(R_{\mathrm{P}}\right)-40$ had taken place already at $80^{\circ} \mathrm{C}$.

3.2.40. Synthesis of

$\left(R_{\mathrm{P}}\right)$-1-Phenyl-2,3,3a,4,9,9a-hexahydrophosphacyclopenta[b]naphthalen-9-ol-borane (41)

$\left(R_{\mathrm{P}}\right)-\mathbf{4 1}$ was obtained in $95 \%$ yield according to typical procedure described in Section 3.2.9. with using $1 \mathrm{M} \mathrm{BH}_{3}$-THF instead of $\mathrm{BH}_{3}-\mathrm{SMe}_{2}$. $\left(R_{\mathrm{P}}\right)-41$ : white crystals, $\mathrm{mp}=104-105^{\circ} \mathrm{C},[\alpha]_{\mathrm{D}}=-34.86(\mathrm{c}$ 1.3, $\left.\mathrm{CHCl}_{3}\right) .{ }^{1} \mathrm{H}$ NMR $\left(\mathrm{CDCl}_{3}, 300 \mathrm{MHz}\right): \delta 7.77-7.73(\mathrm{~m}, 2 \mathrm{H}) ; 7.51-7.44(\mathrm{~m}, 3 \mathrm{H}) ; 7.33-7.21(\mathrm{~m}, 4 \mathrm{H})$; 5.24-5.20 (m, 1H -OH); 3.1-2.92 (m, 2H); 2.85-2.72 (m, 3H); 2.50-2.0 (m, 4H); $1.29-0.30\left(\mathrm{~m}, 3 \mathrm{H}, \mathrm{BH}_{3}\right)$. ${ }^{13} \mathrm{C} \mathrm{NMR}\left(\mathrm{CDCl}_{3}, 75.5 \mathrm{MHz}\right): \delta 139.2(\mathrm{~d}, J=8.2 \mathrm{~Hz}) ; 137.4 ; 132.0(\mathrm{~d}, J=8.8 \mathrm{~Hz}) ; 131.8(\mathrm{~d}, J=2.5 \mathrm{~Hz})$; $131.0(\mathrm{~d}, J=50.3 \mathrm{~Hz}) ; 129.4(\mathrm{~d}, J=9.8 \mathrm{~Hz}) ; 128.6 ; 128.6 ; 127.0 ; 126.9 ; 70.8(\mathrm{~d}, J=1.1 \mathrm{~Hz}, \mathrm{C}-\mathrm{OH}) ; 46.2(\mathrm{~d}$, $J=34.5 \mathrm{~Hz}) ; 39.7(\mathrm{~d}, J=5.4 \mathrm{~Hz}) ; 34.9(\mathrm{~d}, J=4.5 \mathrm{~Hz}) ; 33.5(\mathrm{~d}, J=3.4 \mathrm{~Hz}) ; 26.7(\mathrm{~d}, J=37.3 \mathrm{~Hz}) .{ }^{31} \mathrm{P} \mathrm{NMR}$ $\left(\mathrm{CDCl}_{3}, 121.5 \mathrm{MHz}\right): \delta 32.80$. Elemental Anal. For $\mathrm{C}_{18} \mathrm{H}_{22} \mathrm{BOP}$ : calcd. $\mathrm{C}, 73.00 ; \mathrm{H}, 7.48$; found $\mathrm{C}, 72.91$; $\mathrm{H}, 7.44$.

3.2.41. Synthesis of $\left(S_{\mathrm{P}}\right)$-1-Phenyl-2,3,3a,4,9,9a-hexahydrophosphacyclopenta[b]naphthalen-9-ol 1-sulfide (42)

$\left(S_{\mathrm{P}}\right)-\mathbf{4 2}$ was obtained in $92 \%$ yield according to typical procedure described in Section 3.2.6. $\left(S_{\mathrm{P}}\right)-42$ : white crystals, $\mathrm{mp}=141-142{ }^{\circ} \mathrm{C},[\alpha]_{\mathrm{D}}=+17.59\left(\mathrm{c} 1.02, \mathrm{CHCl}_{3}\right) .{ }^{1} \mathrm{H} \mathrm{NMR}\left(\mathrm{CDCl}_{3}, 300 \mathrm{MHz}\right)$ : 反 7.93-7.85 (m, 2H); 7.60-7.45 (m, 3H); 7.32-7.20 (m, 4H); $5.31(\mathrm{dd}, 1 \mathrm{H}, J=3.1 \mathrm{~Hz}, 8.7 \mathrm{~Hz}) ; 5.03(\mathrm{bs}$, $1 \mathrm{H}-\mathrm{OH}) ; 3.21(\mathrm{dd}, 1 \mathrm{H}, J=8 \mathrm{~Hz}, 14.6 \mathrm{~Hz}) ; 3.06(\mathrm{ddd}, 1 \mathrm{H}, J=2.4 \mathrm{~Hz}, 7.3 \mathrm{~Hz}, 14.7 \mathrm{~Hz}) ; 2.85-2.71(\mathrm{~m}, 1 \mathrm{H})$;

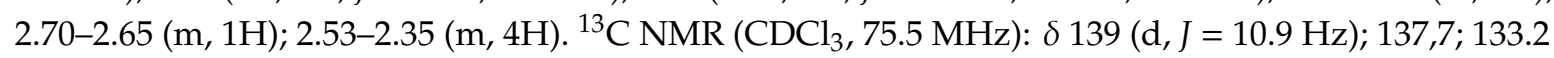
$(\mathrm{d}, J=71.3 \mathrm{~Hz}) ; 132.2(\mathrm{~d}, J=3 \mathrm{~Hz}) ; 130.9(\mathrm{~d}, J=9.8 \mathrm{~Hz}) ; 129.2(\mathrm{~d}, J=11.9 \mathrm{~Hz}) ; 128.7 ; 128.5 ; 127.2 ; 126.8$; $70.8(\mathrm{~d}, J=3.9 \mathrm{~Hz}) ; 47.2(\mathrm{~d}, J=55 \mathrm{~Hz}) ; 39.6(\mathrm{~d}, J=10.8 \mathrm{~Hz}) ; 36.3(\mathrm{~d}, J=52.4 \mathrm{~Hz}) ; 34.3(\mathrm{~d}, J=5.1 \mathrm{~Hz})$; $33.9(\mathrm{~d}, J=8.2 \mathrm{~Hz}) .{ }^{31} \mathrm{P} \mathrm{NMR}\left(\mathrm{CDCl}_{3}, 121.5 \mathrm{MHz}\right): \delta 61.08$. Elemental Anal. For $\mathrm{C}_{18} \mathrm{H}_{19} \mathrm{SOP}$ : calcd. C, 68.76; H, 6.09; found $\mathrm{C}, 68.65 ; \mathrm{H}, 6.05$.

3.2.42. Synthesis of $\left(S_{\mathrm{P}}\right)-1-P h e n y 1-2,3,3 \mathrm{a}, 4,9,9 \mathrm{a}-$ hexahydrophosphacyclopenta[b]naphthalen-9-ol 1-selenide (43)

$\left(S_{\mathrm{P}}\right)$-42 was obtained in $92 \%$ yield according to typical procedure described in Section 3.2.6. $\left(S_{\mathrm{P}}\right)-43$ : white crystals, $\mathrm{mp}=119-120^{\circ} \mathrm{C},[\alpha]_{\mathrm{D}}=+20.07\left(\mathrm{c} 1.02, \mathrm{CHCl}_{3}\right) .{ }^{1} \mathrm{H} \mathrm{NMR}\left(\mathrm{CDCl}_{3}, 300 \mathrm{MHz}\right): \delta$ 7.95-7.86 (m, 2H); 7.55-7.46 (m, 3H); 7.31-7.2 (m, 4H); $5.32(\mathrm{dd}, 1 \mathrm{H}, J=2.3 \mathrm{~Hz}, 8.1 \mathrm{~Hz}) ; 4.95(\mathrm{bs}, 1 \mathrm{H}-\mathrm{OH})$,

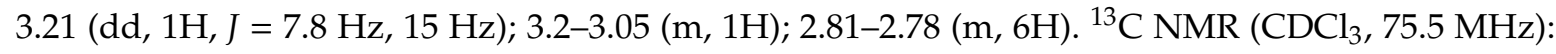


$\delta 138.4(\mathrm{~d}, J=10 \mathrm{~Hz}) ; 137.3(\mathrm{~d}, J=0.7 \mathrm{~Hz}) ; 131.8(\mathrm{~d}, J=62.9 \mathrm{~Hz}) ; 131.1(\mathrm{~d}, J=10.5 \mathrm{~Hz}) ; 128.9(\mathrm{~d}$, $J=11.8 \mathrm{~Hz}) ; 128.4 ; 128.1 ; 126.9 ; 126.4 ; 71.9(\mathrm{~d}, J=3.0 \mathrm{~Hz}) ; 46.8(\mathrm{~d}, J=46.3 \mathrm{~Hz}) ; 39.2(\mathrm{~d}, J=10.3 \mathrm{~Hz})$; $36.3(\mathrm{~d}, J=46.5 \mathrm{~Hz}) ; 33.8(\mathrm{~d}, J=1.2 \mathrm{~Hz}) ; 33.7(\mathrm{~d}, J=3.9 \mathrm{~Hz}) .{ }^{31} \mathrm{P} \mathrm{NMR}\left(\mathrm{CDCl}_{3}, 121.5 \mathrm{MHz}\right): \delta 46.27$. Elemental Anal. for $\mathrm{C}_{18} \mathrm{H}_{19}$ SeOP: calcd. C, 59.84; H, 5.30; found C, 59.68; H, 5.28.

3.2.43. Synthesis of rac-1-[1-Oxido-1-phenyl-2,3,3a,4,9,9a-hexahydro-1H-benzo[f]phosphindol-9-yl]pyridinium Triflate (rac-44)

In a flask equipped with a magnetic stirrer septum were placed $15 \mathrm{~mL}$ of dry DMSO and $10 \mathrm{~mL}$ of pyridine. The stirred mixture was chilled to $0{ }^{\circ} \mathrm{C}$ and $170 \mu \mathrm{L}$ ( $300 \mathrm{mg}, 2 \mathrm{mmol}$ ) of triflic acid was added. Then, $300 \mathrm{mg}$ ( $1 \mathrm{mmol}$ ) of rac-39 disolved in $5 \mathrm{~mL}$ of DMSO was slowly added, and $400 \mathrm{mg}$ $(1.9 \mathrm{mmol}) \mathrm{DCC}$ was added in one portion at $0^{\circ} \mathrm{C}$. The resulting reaction mixture was then stirred for $24 \mathrm{~h}$ at room temperature and, at the end, heated to $60^{\circ} \mathrm{C}$ for additional $2 \mathrm{~h}$. The end point of the reaction was detected by NMR, which indicated a nearly complete conversion of rac-39. The formed DCU was removed by filtration through a syringe filter and a small part of the product crystallized out from the filtrate during cooling to ambient temperature. Due to a minute amount of isolated hardly soluble crystalline rac-44, it was not fully characterized except for an X-ray diffraction analysis which unambiguously confirmed its molecular structure.

\subsection{X-Ray Crystallographic Data}

The X-ray data for compounds rac-19 and rac-26 were collected at 100(2) K on a Nonius Kappa CCD diffractometer [70] using graphite monochromated MoK $\alpha$ radiation $(\lambda=0.71073 \AA)$. The crystals were mounted in a nylon loop in a drop of silicon oil to prevent the possibility of decay of the crystal during data collection. The unit cells' parameters were determined from ten frames and then refined on all data. The data were processed with DENZO and SCALEPACK (HKL2000 package) [71]. The structures were solved by direct methods using the SHELXS-97 [72] program and was refined by full matrix least-squares on $\mathrm{F}^{2}$ using the program SHELXL-97 [73]. All non-hydrogen atoms were refined with anisotropic displacement parameters. The hydrogen atoms were introduced at geometrically idealized coordinates with a fixed isotropic displacement parameter equal to 1.5 (methyl groups) times the value of the equivalent isotropic displacement parameter of the parent carbon.

The X-ray data for complex rac-39a were collected at 293(2) K on an Enraf Nonius MACH3 diffractometer [71] using graphite monochromated $\mathrm{CuK} \alpha$ radiation $(\lambda=1.54178 \AA$ ). The unit cell parameters were determined from ten frames and then refined on all data. The data were processed with OpenMolEN, Nonius BV. The structure was solved by direct methods using the SHELXS97 [71] program and was refined by full matrix least-squares on $\mathrm{F}^{2}$ using the program SHELXL 97 [73] All of the non-hydrogen atoms were refined with anisotropic displacement parameters. The hydrogen atoms were introduced at geometrically idealized coordinates with a fixed isotropic displacement parameter equal to 1.5 (methyl groups) times the value of the equivalent isotropic displacement parameter of the parent carbon.

Crystallographic data for compounds rac-19, rac-26 and rac-44 have been deposited with the Cambridge Crystallographic Data Centre as supplementary publication.: CCDC-1981155 (rac-19), CCDC-1981156 (rac-26) and CCDC-239150 (rac-44). Copies of the data can be obtained free of charge on application to CCDC via www.ccdc.cam.ac.uk/data_request/cif, or by e-mail data_request@ccdc.cam.ac.uk.

Crystal data for rac-19: $\mathrm{C}_{15} \mathrm{H}_{19} \mathrm{P}_{1} \mathrm{O}_{1}: M=246.27$, orthorhombic, space group $P 2_{1} 2{ }_{1} 2_{1}$ (no. 19), $a=9.4360(2) \AA, b=11.3710(2) \AA, c=11.5660(2) \AA, U=1240.99(4) \AA^{3}, Z=4, F(000)=528, D_{c}=1.318$ $\mathrm{g} \mathrm{cm}^{-3}, T=100(2) \mathrm{K}, \mu(\mathrm{Mo}-\mathrm{K} \alpha)=0.202 \mathrm{~mm}^{-1}, \theta_{\max }=27.505^{\circ}, 2833$ unique reflections. Refinement converged at $R 1=0.0346, w R 2=0.0816$ for all data and 154 parameters $(R 1=0.0317, w R 2=0.0803$ for 2716 reflections with $\left.I_{o}>2 \sigma\left(I_{0}\right)\right)$. The goodness-of-fit on $\mathrm{F}^{2}$ was equal 1.052. A weighting scheme 
$w=\left[\sigma^{2}\left(F_{\mathrm{o}}\right)^{2}+(0.0418 P)^{2}+3.1964 P\right]^{-1}$ where $P=\left(F_{\mathrm{o}}{ }^{2}+2 F_{\mathrm{c}}{ }^{2}\right) / 3$ was used in the final stage of refinement. The residual electron density $=+0.24 /-0.24 \mathrm{e}^{-3}$.

Crystal data for rac-26: $\mathrm{C}_{16} \mathrm{H}_{22} \mathrm{P}_{1} \mathrm{~B}_{1}: M=256.11$, monoclinic, space group $P 21$ (no. 4), $a=6.37100(10) \AA, b=13.5760(3) \AA, c=8.4160(2) \AA, \beta=101.4930(10)^{\circ}, U=713.33(3) \AA^{3}, Z=2$, $F(000)=276, D_{\mathrm{c}}=1.192 \mathrm{~g} \mathrm{~cm}^{-3}, T=100(2) \mathrm{K}, \mu(\mathrm{Mo}-\mathrm{K} \alpha)=0.172 \mathrm{~mm}^{-1}, \theta_{\max }=27.471^{\circ}, 2639$ unique reflections. Refinement converged at $R 1=0.0367, w R 2=0.0946$ for all data and 180 parameters $\left(R 1=0.0352, w R 2=0.0924\right.$ for 2566 reflections with $\left.I_{o}>2 \sigma\left(I_{o}\right)\right)$. The goodness-of-fit on $\mathrm{F}^{2}$ was equal 1.063. A weighting scheme $w=\left[\sigma^{2}\left(F_{\mathrm{o}}\right)^{2}+(0.0418 P)^{2}+3.1964 P\right]^{-1}$ where $P=\left(F_{\mathrm{o}}{ }^{2}+2 F_{\mathrm{c}}{ }^{2}\right) / 3$ was used in the final stage of refinement. The residual electron density $=+0.25 /-0.30 \mathrm{e}^{-3}$.

Crystal data for rac-44: $\mathrm{C}_{24} \mathrm{H}_{25} \mathrm{P}_{1} \mathrm{~S}_{1} \mathrm{~F}_{3} \mathrm{~N}_{1} \mathrm{O}_{5}: \mathrm{M}=246.27$, triclinic, space group $\mathrm{P}-1$ (no. 2), $\mathrm{a}=9.6444(6) \AA, \mathrm{b}=11.0887(7) \AA, \mathrm{c}=11.7985(7), \AA, \alpha=95.281(5)^{\circ}, \beta=105.384(5)^{\circ}, \gamma=95.097(5)^{\circ}$, $\mathrm{U}=1202.94(13) \AA^{3}, \mathrm{Z}=2, \mathrm{~F}(000)=548, \mathrm{D}_{\mathrm{c}}=1.456 \mathrm{~g} \mathrm{~cm}^{-3}, \mu(\mathrm{Mo}-\mathrm{K} \alpha)=2.363 \mathrm{~mm}^{-1}, \theta_{\max }=74.24^{\circ}$, 3948 unique reflections. Refinement converged at $\mathrm{R} 1=0.0858, \mathrm{wR} 2=0.1772$ for all data and 337 parameters. The goodness-of-fit on $\mathrm{F}^{2}$ was equal 1.430. A weighting scheme $\mathrm{w}=\left[\sigma^{2}\left(\mathrm{~F}_{\mathrm{o}}\right)^{2}+(0.0418 \mathrm{P})^{2}\right.$ $+3.1964 \mathrm{P}]^{-1}$, where $\mathrm{P}=\left(\mathrm{F}_{\mathrm{o}}^{2}+2 \mathrm{~F}_{\mathrm{c}}^{2}\right) / 3$ was used in the final stage of refinement. The residual electron density $=+0.67 /-0.31 \mathrm{e}^{-3}$.

Crystal data for rac-39: There are no complete crystallographic data for rac-39. The overview picture was built based on the RES file whose quality was sufficient to determine the relative configuration of the substituents.

\section{Conclusions}

In summary, an efficient procedure for accessing gram quantities of both enantiomers of 1-phenylphosphole-2-ene 1-oxide (1) in a single resolution process has been optimized and is described in full reproducible details. The resolved 1 has been shown to undergo stereoselective Diels-Alder cycloadditions with cyclic dienes. The dienes approach the phospholene oxide in the endo mode and exclusively from its $\mathrm{P}=\mathrm{O}$ bearing side. The cycloadditions led to synthesis of virtually enantiopure bicyclic and polycyclic phosphine oxides of the phosphindole, functionalized benzophosphindole, phospha[5.2.1. $\left.0^{2,6}\right]$ decane, phospha[5.2.2.0 $\left.0^{2,6}\right]$ undecane and dibenzophospha[5.2.2.0 $\left.0^{2,6}\right]$ undecane ring systems containing resolved P-stereogenic centre embeded in the five-membered ring. The cycloadducts were shown to undergo fully stereoselective conversions to the corresponding bicyclic and polycyclic phosphines as well as to their borane, sulfide, and selenide derivatives with complete retention of configuration at P. Unexpectedly, for a tricyclic phosphine $\left(R_{\mathrm{P}}\right)-\mathbf{4 0}$ bearing a $\beta$-hydroxy substituent, an apparently lowered P-inversion barrier has been revealed during its attempted synthesis from oxide $\left(S_{\mathrm{P}}\right)-39$ by stereoretentive reduction with $\mathrm{PhSiH}_{3}$ at $80{ }^{\circ} \mathrm{C}$. The synthesized enantiomerically pure polycyclic P (III) derivatives have the potential to serve as the P-stereogenic monophosphine ligands in asymmetric catalysis. Studies along these lines are currently in progress in our laboratories.

Author Contributions: Conceptualization and supervision, K.M.P.; investigation, M.K., Z.D., R.P., E.t., and O.M.D.; X-ray analyses, I.J.; writing, K.M.P.; review and editing, E.Ł. and O.M.D. All authors have read and agreed to the published version of the manuscript.

Funding: This research received no external funding.

Conflicts of Interest: The authors declare no conflict of interest.

\section{References}

1. Dutartre, M.; Bayardon, J.; Jugé, S. Applications and stereoselective syntheses of P-chirogenic phosphorus compounds. Chem. Soc. Rev. 2016, 45, 5771-5794. [CrossRef]

2. Grabulosa, A. P-Stereogenic Ligands in Enantioselective Catalysis; RSC Catalysis Series; RSC: Cambridge, UK, 2011.

3. Marinetti, A.; Voituriez, A. Enantioselective Phosphine Organocatalysis. Synlett 2010, 21, 174-194. [CrossRef]

4. Ni, H.; Cha, W.-L.; Lu, Y. Phosphine-Catalyzed Asymmetric Organic Reactions. Chem. Rev. 2018, 118, 9344-9411. [CrossRef] [PubMed] 
5. Vineyard, B.D.; Knowles, W.S.; Sabacky, M.J.; Bachman, G.L.; Weinkauff, O.J. Asymmetric hydrogenation -rhodium chiral bis-phosphine catalyst. J. Am. Chem. Soc. 1977, 99, 5946-5952. [CrossRef]

6. Knowles, W.S. Asymmetric hydrogenation. Acc. Chem. Res. 1983, 16, 106-112. [CrossRef]

7. Pietrusiewicz, K.M.; Zabłocka, M. Preparation of scalemic P-chiral phosphines and their derivatives. Chem. Rev. 1994, 94, 1375-1411. [CrossRef]

8. Grabulosa, A.; Granell, J.; Mueller, G. Preparation of optically pure P-stereogenic trivalent phosphorus compounds. Coord. Chem. Rev. 2007, 251, 25-90. [CrossRef]

9. Cardellicchio, C.; Fiandanese, V.; Naso, F.; Pacifico, S.; Koprowski, M.; Pietrusiewicz, K.M. A novel displacement route to P-chiral phosphine oxides of high enantiomeric purity. Tetrahedron Lett. 1994, 35, 6343-6346. [CrossRef]

10. Pietrusiewicz, K.M. Stereoselective Synthesis and Resolution of P-Chiral Phosphine Chalcogenides. Phosphorus Sulfur Silicon 1996, 109/110, 573-576.

11. Kolodiazhnyi, O.I. Asymmetric synthesis of organophosphorus compounds. Tetrahedron Asymmetry 1998, 9, 1279-1332. [CrossRef]

12. Glueck, D.S. Catalytic asymmetric synthesis of chiral phosphanes. Chem. Eur. J. 2008, 14, 7108-7117. [CrossRef] [PubMed]

13. Adams, H.; Collins, R.C.; Jones, S.; Warner, J.A. Enantioselective preparation of P-chiral phosphine oxides. Org. Lett. 2011, 13, 6576-6579. [CrossRef] [PubMed]

14. Kolodiazhnyi, O.I. Recent developments in the asymmetric synthesis of P-chiral phosphorus compounds. Tetrahedron Asymmetry 2012, 23, 1-46. [CrossRef]

15. Xu, Q.; Zhao, C.-Q.; Han, L.-B. Stereospecific nucleophilic substitution of optically pure $H$-phosphinates: A general way for the preparation of chiral P-stereogenic phosphine oxides. J. Am. Chem. Soc. 2008, 130, 12648-12655. [CrossRef]

16. Han, Z.S.; Goyal, N.; Herbage, M.A.; Sieber, J.D.; Qu, B.; Xu, Y.; Zhibin, L.; Reeves, J.T.; Desrosiers, J.; Ma, S.; et al. Efficient asymmetric synthesis of $P$-chiral phosphine oxides via properly designed and activated benzoxazaphosphinine-2-oxide agents. J. Am. Chem. Soc. 2013, 135, 2474-2477. [CrossRef]

17. Kolodyazhnyi, O.M.; Valery, P.; Kukhar, V.P.; Kolodiazhna, A.O. Asymmetric catalysis as a method for the synthesis of chiral organophosphorus compounds. Tetrahedron Asymmetry 2014, 25, 25865-25922. [CrossRef]

18. Copey, L.; Jean-Gérard, L.; Framery, E.; Pilet, G.; Robert, V.; Andrioletti, B. Experimental and theoretical investigations of the stereoselective synthesis of P-stereogenic phosphine. Chem. Eur. J. 2015, 21, 9057-9061. [CrossRef]

19. Pakulski, Z.; Koprowski, M.; Pietrusiewicz, K.M. Chiral base Promoted Enantioselective Rearrangement of Organophosphorus Epoxides. Tetrahedron 2003, 59, 8219-8226. [CrossRef]

20. Pakulski, Z.; Pietrusiewicz, K.M. Enantioselective desymmetrization of phospholene meso-epoxide by nucleophilic opening of the epoxide ring. Tetrahedron Asymmetry 2004, 15, 41-45. [CrossRef]

21. Kobayashi, S.; Shiraishi, N.; Lam, W.W.-L.; Manabe, K. Asymmetric synthesis of proline and pipecolic acid phosphorous analogues using enantioselective deprotonation-carboxylation reactions. Tetrahedron Lett. 2001, 42, 7303-7306. [CrossRef]

22. Nishida, G.; Noguchi, K.; Hirano, M.; Tanaka, K. Enantioselective synthesis of P-stereogenic alkynylphosphine oxides by Rh-catalyzed [2+2+2] cycloaddition. Angew. Chem. Int. Ed. 2008, 47, 3410-3413. [CrossRef] [PubMed]

23. Harvey, J.S.; Malcolmson, S.J.; Dunne, K.S.; Meek, S.J.; Thompson, A.L.; Schrock, R.R.; Hoveyda, A.H.; Gouverneur, V. Enantioselective Synthesis of P-Stereogenic Phosphinates and Phosphine Oxides by Molybdenum-Catalyzed Asymmetric Ring-Closing Metathesis. Angew. Chem., Int. Ed. 2009, 48, 762-766. [CrossRef] [PubMed]

24. de Azambuja, F.; Carmona, R.C.; Chorro, T.H.D.; Heerdt, G.; Correia, C.R.D. Noncovalent substrate-directed enantioselective Heck reactions: Synthesis of S- and P-stereogenic Heterocycles. Chem. Eur. J. 2016, 22, 11205-11209. [CrossRef] [PubMed]

25. Wang, Z.; Hayashi, T. Rhodium-catalyzed enantioposition-selective hydroarylation of divinylphosphine oxides with aryl boroxines. Angew. Chem. Int. Ed. 2018, 57, 1702-1706. [CrossRef] [PubMed]

26. Jang, Y.-S.; Woźniak, Ł.; Pedroni, J.; Cramer, N. Access to P- and axially chiral biaryl phosphine oxides by enantioselective CpxIrIII-catalyzed C-H arylations. Angew. Chem., Int. Ed. 2018, 57, 12901-12905. [CrossRef] 
27. Zhang, Y.; Zhang, F.; Chen, L.; Xu, J.; Liu, X.; Feng, X. Asymmetric synthesis of P-stereogenic compounds via Thulium-(III)-catalyzed desymmetrization of dialkynylphosphine oxides. ACS Catal. 2019, 9, 4834-4840. [CrossRef]

28. Goti, A.; Cicchi, S.; Brandi, A.; Pietrusiewicz, K.M. THA Nitrone Cycloadditions to 2,3-Dihydro-1-phenyl-1H-phosphole 1-Oxide. Double Asymmetric Reaction and Kinetic Resolution by a Chiral Nitrone. Tetrahedron Asymmetry 1991, 2, 1371-1378. [CrossRef]

29. Pietrusiewicz, K.M.; Wieczorek, W.; Goti, A.; Brandi, A. Optically active phosphine oxides. 15. Stereochemistry and X-ray structure of the major cycloadduct derived from racemic 1-phenyl-2-phospholene 1-oxide and homochiral nitrone. Phosphorus Sulfur Silicon 1992, 70, 131-137. [CrossRef]

30. Brandi, A.; Cicchi, S.; Goti, A.; Koprowski, M.; Pietrusiewicz, K.M. Kinetic Resolution in 1,3-Dipolar Cycloaddition of Tartaric Acid Derived Nitrones to 2,3-Dihydro-1-phenyl-1H-phospholes. An Enantioselective Approach to the 2,2'-Coupled Pyrrolidine-Phospholane Ring System. J. Org. Chem. 1994, 59, 1315-1318. [CrossRef]

31. Kiełbasiński, P.; Żurawiński, R.; Pietrusiewicz, K.M.; Zabłocka, M.; Mikołajczyk, M. Enzymatic Resolution of Racemic Phosphinylacetates Having a Stereogenic Centre at Phosphorus. Tetrahedron Lett. 1994, 35, 7081-7084. [CrossRef]

32. Bergin, E.; O'Connor, C.T.; Robinson, S.B.; McGarrigle, E.M.; O’Mahony, C.P.; Gilheany, D.G. Synthesis of P-stereogenic phosphorus compounds. Asymmetric oxidation of phosphines under Appel conditions. J. Am. Chem. Soc. 2007, 129, 9566-9567. [CrossRef] [PubMed]

33. Lim, K.M.-H.; Hayashi, T. Dynamic Kinetic Resolution in Rhodium-Catalyzed Asymmetric Arylation of Phospholene Oxides. J. Am. Chem. Soc. 2017, 139, 8122-8125. [CrossRef]

34. Fernández-Pérez, H.; Vidal-Ferran, A. Stereoselective catalytic synthesis of P-stereogenic oxides via hydrogenative kinetic resolution. Org. Lett. 2019, 21, 7019-7023. [CrossRef] [PubMed]

35. Drabowicz, J.; Łyżwa, P.; Omelańczuk, J.; Pietrusiewicz, K.M.; Mikołajczyk, M. New Procedures for the Resolution of Chiral tert-Butylphenylphosphine Oxide and Some of Its Reactions. Tetrahedron Asymmetry 1999, 10, 2757-2763. [CrossRef]

36. Blodgett, J.; Wang, Y.; Li, T.; Polavarapu, P.L.; Drabowicz, J.; Pietrusiewicz, K.M.; Zygo, K. Resolution of tert- Butyl-1-(2-Methylnaphthyl)phosphine Oxide Using Selectors Identified from a Chemical Combinatorial Library. Anal. Chem. A 2002, 74, 5212-5216. [CrossRef] [PubMed]

37. Holt, J.; Maj, A.M.; Schudde, E.P.; Pietrusiewicz, K.M.; Sieron, L.; Wieczorek, W.; Jerphagnon, T.; Arends, I.W.C.E.; Hanefeld, U.; Minnaard, A.J. On the resolution of Secondary Phosphine Oxides via Diastereomeric Complex Formation: The Case of tert-Butylphenylphosphine Oxide. Synthesis 2009, 12, 2061-2065.

38. Pakulski, Z.; Demchuk, O.M.; Frelek, J.; Luboradzki, R.; Pietrusiewicz, K.M. New monodentate P,C-stereogenic phosphines: 2-phenyl-2-phosphabicyclo[3.3.0]oct-3-ene and 2-phenyl-2-phosphabicyclo[3.3.0]oct-3-ane. Eur. J. Org. Chem. 2004, 3913-3918. [CrossRef]

39. Dziuba, K.; Flis, A.M.; Szmigielska, A.; Pietrusiewicz, K.M. Efficient oxidative resolution of a P-stereogenic triarylphosphine and asymmetric synthesis of atropoisomeric biphenyl diphosphine dioxide. Tetrahedron Asymmetry 2010, 21, 1401-1405. [CrossRef]

40. Bagi, P.; Ujj, V.; Czugler, M.; Fogassy, E.; Keglevich, G. Resolution of P-stereogenic P-heterocycles via the formation of diastereomeric molecular and coordination complexes (a review). Dalton Trans. 2016, 45, 1823-1842. [CrossRef]

41. Sun, X.-M.; Manabe, K.; Lam, W.W.-L.; Shiraishi, N.; Kobayashi, J.; Shiro, M.; Utsumi, H.; Kobayashi, S. Synthesis of new chiral source, $(1 R, 2 S)$-1-phenylphospholane-2 carboxylic acid, via a key intermediate $\alpha$-phenylphospholanyllithium borane complex: Configurational stability and X-ray crystal structure of an $\alpha$-monophosphinoalkyllithium borane complex. Chem. Eur. J. 2005, 11, 361-368. [CrossRef]

42. Bodalski, R.; Rutkowska-Olma, E.; Pietrusiewicz, K.M. Optically Active Phosphine Oxides. Synthesis and Absolute Configuration of Enantiomeric Phenylvinylcarbomenthoxymethylphosphine Oxide. Tetrahedron 1980, 36, 2353-2355. [CrossRef]

43. Pietrusiewicz, K.M.; Wieczorek, W. X-Ray Structure of $\left(S_{\mathrm{P}}\right)$-L-menthyl (2-methoxyphenyl)phenylphosphinylacetate and assignment of configuration in menthyl phosphinylacetates. Phosphorus Sulfur Silicon 1993, 82, 99-107. [CrossRef] 
44. Pietrusiewicz, K.M.; Zabłocka, M.; Monkiewicz, J. Optically active phosphine oxides. 2. Novel approach to enantiomeric dialkylphenyl-phosphine oxides. J. Org. Chem. 1984, 49, 1522-1526. [CrossRef]

45. Quin, L.D. The Heterocyclic Chemistry of Phosphorus. Systems Based on Phosphorus-Carbon Bond; Wiley-Interscience: New York, NY, USA, 1981; Chapter 2.

46. Morris, D.L.; Berlin, K.D. C-P Heterocycles. VI. Hexahydrophosphindolines from Diels-Alder Reaction. Phosphorus 1974, 4, 69-71.

47. Chan, T.H.; Wong, L.T.L. Benzo[b]phosphole and derivatives. Can. J. Chem. 1971, 49, 530-531. [CrossRef]

48. Bianchini, C.; Cicchi, S.; Peruzzini, M.; Pietrusiewicz, K.M.; Brandi, A. A new P-chiral aminophosphine ligand containing a $2,2^{\prime}$-coupled pyrrolidine-phospholane ring system. Synthesis and coordination properties with rhodium(I) and iridium(I) fragments. J. Chem. Soc. Chem. Commun. 1995, 833-834. [CrossRef]

49. Pietrusiewicz, K.M.; Hołody, W.; Koprowski, M.; Cicchi, S.; Goti, A.; Brandi, A. Asymmetric and doubly asymmetric 1,3-dipolar cycloadditions in the synthesis of enantiopure organophosphorus compounds. Phosphorus, Sulfur Silicon 1999, 144/146, 389-392. [CrossRef]

50. Desmazeau, P.; Legros, P.; Fiaud, J.C. Palladium-catalyzed reactions of 1-phenylphospholene-1-oxides with aryl iodides and aryldiazonium salts. Tetrahedron Lett. 1998, 39, 6707-6710. [CrossRef]

51. Moeller, S.; Drzazga, Z.; Pakulski, Z.; Pietrusiewicz, K.M.; Duddeck, H. The dirhodium-method in the determination of absolute configurations of phospholene chalcogenides. Chirality 2006, 18, 395-397. [CrossRef]

52. McEwen, W.; Kumli, K.F.; Blade-Font, A.; Zanger, M.; VanderWerf, C.A. Mechanisms of Substitution Reactions at Phosphorus. X. The Wittig Reaction and the Decomposition of Quaternary Phosphonium Hydroxides. J. Am. Chem. Soc. 1964, 86, 2378-2384. [CrossRef]

53. Trost, B.M.; Curran, D.P. An Enantiodirected Cyclopentenone Annulation. Synthesis of a Useful Building Block for Condensed Cyclopentanoid Natural Products. J. Am. Chem. Soc. 1980, 102, 5699-5700. [CrossRef]

54. Marsi, K.L.; Tuinstra, H. Complete Resolution of ci's-l-Benzyl-3-methyl-1-phenylphospholanium Iodide. Use of the Optically Active Salt in Stereochemical Studies. J. Org. Chem. 1975, 40, 1843-1844. [CrossRef]

55. Pakulski, Z.; Demchuk, O.; Kwiatosz, R.; Osiński, P.; Świerczyńska, W.; Pietrusiewicz, K.M. The Classical Kagan's amides are still practical NMR chiral shift reagents: Determination of enantiomeric purity of P-chirogenic phospholenes. Tetrahedron Asymmetry 2003, 14, 1459-1462. [CrossRef]

56. Bodalski, R.; Koszuk, J.; Krawczyk, H.; Pietrusiewicz, K.M. An Efficient Synthesis of Enantiomeric 17-Phosphasteroid System. J. Org. Chem. 1982, 20, 83-91. [CrossRef]

57. Breque, A.; Alcaraz, J.-M.; Ricard, L.; Mathey, F.; Tambute, A.; Macaudiere, P. Use of prochiral phosphaalkene complexes in the synthesis of optically active phosphines. New J. Chem. 1989, 13, 369-374.

58. Möller, T.; Wonneberger, P.; Sárosi, M.B.; Coburger, P.; Hey-Hawkins, E. P-chiral 1-phosphanorbornenes: From asymmetric phospha-Diels-Alder reactions towards ligand design and functionalization. Dalton Trans. 2016, 45, 1904-1916. [CrossRef]

59. Leung, P.H. Asymmetric Synthesis and Organometallic Chemistry of Functionalized Phosphines Containing Stereogenic Phosphorus Centers. Acc. Chem. Res. 2004, 37, 169-177. [CrossRef]

60. Oshchepkova, E.S.; Zagidullin, A.A.; Miluykov, V.A.; Sinyashin, O.G. Substituent effects in the asymmetric Diels-Alder cycloaddition of 3,4,5-triaryl-1-(+)-neomenthyl-1,2-diphosphole with maleic acid derivatives. Phosphorus Sulfur Silicon Relat. Elem. 2016, 191, 1530-1532. [CrossRef]

61. Marsi, K.L. Phenylsilane reduction of phosphine oxides with complete stereospecificity. J. Org. Chem. 1974, 39, 265-267. [CrossRef]

62. Demchuk, O.M.; Jasiński, R.; Pietrusiewicz, K.M. New Insights into the Mechanism of Reduction of Tertiary Phosphine Oxides by Means of Phenylsilane. Heteroatom Chem. 2015, 26, 441-448. [CrossRef]

63. Horner, L.; Winkler, H.; Rapp, A.; Mentrup, A.; Hoffmann, H.; Beck, P. Phosphororganische verbindungen optisch aktive tertiäre phosphine aus optisch aktiven quartären phosphoniumsalzen. Tetrahedron Lett. 1961, 2, 161-166. [CrossRef]

64. McNulty, J.; Zhou, Y. A highly efficient general synthesis of phosphine-borane complexes. Tetrahedron Lett. 2004, 45, 407-409. [CrossRef]

65. Szwaczko, K.; Demchuk, O.M.; Mirosław, B.; Strzelecka, D.; Pietrusiewicz, K.M. Straightforward approach to norbornene core based chiral ligands by tandem cross dehydrogenative coupling reactions. Tetrahedron Lett. 2016, 57, 3491-3495. [CrossRef] 
66. Pietrusiewicz, K.M.; Szwaczko, K.; Mirosław, B.; Dybała, I.; Jasiński, R.; Demchuk, O.M. New rigid polycyclic bis(phosphane) for asymmetric catalysis. Molecules 2019, 24, 571. [CrossRef] [PubMed]

67. Choy, W.; Yang, H. Diels-Alder reactions of $\alpha$-oxy-o-xylylenes. J. Org. Chem. 1988, 53, 5796-5798. [CrossRef]

68. Frynas, S.; Łastawiecka, E.; Kozioł, A.E.; Flis, A.; Pietrusiewicz, K.M. [4+2] Cycloaddition of vinylphosphine oxides to $\alpha$-oxy-o-xylylene as a route to phosphorylated naphthyl and biarylscaffolds. J. Org. Chem. 2019, 84, 1818-1832. [CrossRef]

69. Neises, B.; Steglich, W. Simple Method for the Esterification of Carboxylic Acid. Angew. Chem. Int. Ed. 1978, 17, 522-524. [CrossRef]

70. Hooft, R. Kappa CCD Software; Enraf-Nonius B.V.: Delft, The Netherlands, 1998.

71. Otwinowski, Z.; Minor, W. Processing of X-ray diffraction data collected in oscillation mode. Methods Enzymol. 1997, 276, 307.

72. Sheldrick, G.M. A short history of SHELX. Acta Cryst. 2008, 64A, 112-122. [CrossRef]

73. Sheldrick, G.M. SHELXS-97 and SHELXL-97, Program for Crystal Structure Solution and Refinement; University Göttingen: Göttingen, Germany, 1997.

(C) 2020 by the authors. Licensee MDPI, Basel, Switzerland. This article is an open access article distributed under the terms and conditions of the Creative Commons Attribution (CC BY) license (http://creativecommons.org/licenses/by/4.0/). 